\title{
DETERMINAÇÃO DA PUREZA VARIETAL EM LOTES DE SEMENTES DE MILHO ATRAVÉS DE MARCADORES MORFOLÓGICOS E MICROSSATÉLITES
}

\author{
Nilza Patrícia Ramos
}

Tese apresentada à Escola Superior de Agricultura "Luiz de Queiroz", Universidade de São Paulo, para obtenção do título de Doutor em Agronomia, Área de Concentração: Fitotecnia.

PIR A CICAB A

Estado de São Paulo - Brasil

Setembro - 2004 


\title{
DETERMINAÇÃO DA PUREZA VARIETAL EM LOTES DE SEMENTES DE MILHO ATRAVÉS DE MARCADORES MORFOLÓGICOS E MICROSSATÉLITES
}

\author{
Nilza Patrícia Ramos
}

Engenheiro Agrônomo

Orientador: Prof. Dr. JULIO MARCOS FILHO

Co-orientador: Prof. Dr. LUIS EDUARDO ARANHA CAMARGO

Tese apresentada à Escola Superior de Agricultura "Luiz de Queiroz", Universidade de São Paulo, para obtenção do título de Doutor em Agronomia, Área de Concentração: Fitotecnia.

PIR A C I C A B A

Estado de São Paulo - Brasil

Setembro - 2004 
Dados Internacionais de Catalogação na Publicação (CIP)
DIVISÃO DE BIBLIOTECA E DOCUMENTAÇÃO - ESALQ/USP

Ramos, Nilza Patrícia

Determinação da pureza varietal em lotes de sementes de milho através de marcadores morfológicos e microssatélites / Nilza Patrícia Ramos. - - Piracicaba, 2004.

104 p. : il.

Tese (Doutorado) - - Escola Superior de Agricultura Luiz de Queiroz, 2004. Bibliografia.

1. Linhagem vegetal 2. Marcador molecular 3. Milho 4. Sementes - Qualidade I. Título

CDD 633.15

"Permitida a cópia total ou parcial deste documento, desde que citada a fonte - O autor" 


\begin{abstract}
À minha família pelo carinho, compreensão, incentivo e apoio constante...
\end{abstract}

\title{
Ofereço
}

Aos meus pais Maria Lúcia e Nilson por toda dedicação e amor incondicional... 


\section{AGRADECIMENTOS}

À Escola Superior de Agricultura "Luiz de Queiroz" (USP/ESALQ) pela oportunidade de realizar o curso de Doutorado

Ao Professor Dr. Julio Marcos Filho pela orientação, apoio, confiança e dedicação durante estes anos.

Ao Professor Dr. Luis Eduardo Aranha Camargo pela co-orientação e apoio no desenvolvimento de parte dessa pesquisa.

Aos meus pais Nilson e Maria Lúcia, meus irmãos Érica, Natália e Gustavo por todo carinho, apoio, compreensão e paciência. Também à vovó Ana e tia Célia por todo o amor e presença constante em minha vida.

A Capes pela bolsa de auxílio concedida durante a realização da pesquisa.

À empresa Dow AgroSciences pelo fornecimento das sementes e do campo experimental localizado no município de Cravinhos -SP. Também, aos colegas Nelson Scavone, Roberto Carvalho e Luversi pela ajuda dispensada e conhecimento compartilhado que contribuíram para a realização da pesquisa.

Aos professores do Departamento de Produção Vegetal da ESALQ/USP pela oportunidade de aprendizado, sugestões e auxílio durante a elaboração deste trabalho.

Às Engenheiras Agrônomas Helena M.C.P. Chamma, Maria Heloísa D. Moraes e Ana Dionísia L.C. Novembre, pela colaboração e sugestões durante a condução do trabalho.

Aos amigos conquistados nessa fase de minha vida Adriana Pedroso, Ana Paula Teixeira, Ariana, Fátima, Kátia Brunelli, Magali, Otávio, Roseli, Virgínia, Silvia Pasqua, 
Solidete e Walnice pelo companheirismo, apoio, paciência e compreensão nos momentos difíceis e também pelos agradáveis instantes de lazer.

Aos amigos de longa data Andréia, Elisabeth, Melissa, Roselene, Sheila, Prof. Nelson Carvalho e Prof. Rinaldo que sempre permanecem ao meu lado, contribuindo com sua atenção e dedicação em todos os momentos.

Aos colegas do Laboratório de Sementes Angélica, Ana Lúcia, Ebert, Maria Cristina pela convivência e todo o auxílio técnico-científico durante o trabalho, além do agradável convívio.

Aos colegas do Laboratório de Genética Molecular Alessandra Penha, Ana Carolina, Camila, Cândido, Cláudia, Daniel, Daniela, Flávia, Júlia, Marcelo, Maria Cristina, Osmar, Paulo, Raphaelle, Reinaldo, Rodrigo, Sandra, Vanoli, Viviane e Thayne pela ajuda, amizade e inesquecível convivência.

A todos os colegas do curso de pós-graduação em Fitotecnia pela amizade e bons momentos compartilhados.

Às secretárias Luciane Aparecida Lopes e Ilze Helena C.G. das Neves pela amizade e auxílio prestados durante o curso

Aos funcionários João E. Jabur Filho e Edson Tanaka por todo apoio e auxílio na condução de experimentos. Também à Flávia Oliveira e Nilda pela colaboração na limpeza do laboratório e Pavilhão de Tecnologia de Sementes.

A todos que direta ou indiretamente contribuíram para a execução deste trabalho. 


\section{SUMÁRIO}

Página

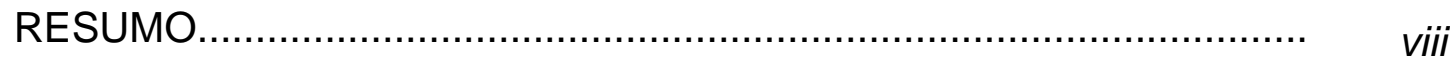

SUMMARY

1 INTRODUÇÃO

2 REVISÃO DE LITERATURA ...................................................................

2.1 Marcadores morfológicos para análise de pureza varietal......................... 5

2.2 Marcadores moleculares para análise de pureza varietal ......................... 9

3 MATERIAL E MÉTODOS................................................................ 18

3.1 Caracterização preliminar...................................................................... 19

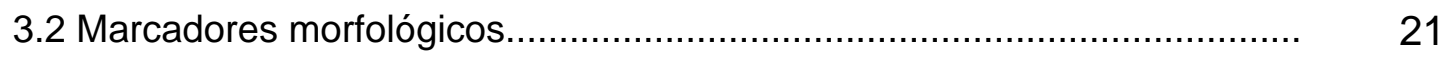

3.2.1 Avaliação de sementes...................................................................... 21

3.2.2 Avaliação de plântulas.......................................................................... 22

3.2.3 Avaliação de plantas em campo........................................................... 23

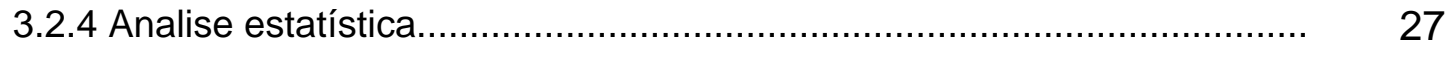

3.3 Marcadores microssatélites.............................................................. 28

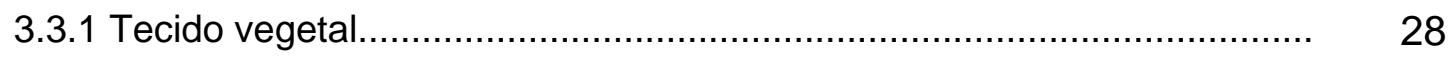




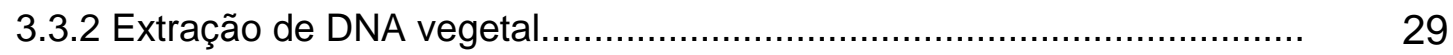

3.3.3 Amplificação de locos microssatélites............................................. 30

3.3.4 Resolução dos fragmentos amplificados........................................... 32

3.3.5 Sensibilidade dos marcadores microssatélites para avaliar pureza varietal através da simulação de contaminação em amostras de DNA

4 RESULTADOS E DISCUSSÃO.

4.1 Caracterização preliminar.

4.2 Marcadores morfológicos.

40

4.2.1 Avaliação de sementes.............................................................. 40

4.2.2 Avaliação de plântulas................................................................ 44

4.2.3 Avaliação de plantas em campo.................................................. 53

4.3 Marcadores microssatélites........................................................ 67

4.3.1 Tecido vegetal para extração de DNA .................................................. 67

4.3.2 Amplificação via PCR de locos miocrossatélites para avaliação de pureza varietal em lotes de sementes.

4.3.3 Sensibilidade dos marcadores microssatélites para avaliar pureza varietal através da simulação de contaminação em amostras de DNA.

4.4 Comparação entre marcadores morfológicos e moleculares para a determinação de pureza varietal.

5 CONCLUSÕES. 


\title{
DETERMINAÇÃO DA PUREZA VARIETAL EM LOTES DE SEMENTES DE MILHO ATRAVÉS DE MARCADORES MORFOLÓGICOS E MICROSSATÉLITES
}

\author{
Autora: NILZA PATRÍCIA RAMOS \\ Orientador: Prof. Dr. JULIO MARCOS FILHO \\ Co-orientador: Prof. Dr. LUIS EDUARDO ARANHA CAMARGO
}

\section{RESUMO}

A presença de cultivares indesejáveis em lotes de linhagens de milho não é tolerada, pois compromete a eficiência da multiplicação subsequente para a produção comercial de sementes. A detecção das sementes contaminantes é realizada através de testes para determinação da pureza varietal e/ou genética, os quais, geralmente, são baseados em marcadores morfológicos e bioquímicos. Devido à importância dessa determinação, métodos alternativos eficientes vêm sendo avaliados e, entre esses merecem destaque os baseados em polimorfismo de DNA, visando a obtenção de informações mais consistentes. Nesse sentido, esta pesquisa teve como objetivo principal a comparação da eficiência de marcadores morfológicos e microssatélites para avaliação de pureza varietal de 
linhagens de milho e a determinação do grau de sensibilidade da técnica de microssatélites para detectar a ocorrência de genótipos contaminantes em lotes de sementes. Utilizaram-se quatro linhagens (L1, L2, L3 e L4) fornecidas pela Dow AgroSciences Ltda., misturadas duas a duas, para a obtenção de níveis de contaminação de 0, 1, 2, 5, 10 e 100\%. L1 e L3 foram consideradas linhagens puras, enquanto L2 e L4 foram tratadas como genótipos contaminantes. A avaliação mediante o uso de marcadores morfológicos foi realizada utilizando-se descritores para sementes, plântulas e plantas em diferentes estádios de desenvolvimento. $\mathrm{Na}$ técnica de microssatélites utilizaram-se iniciadores específicos para amplificar DNA isolado a partir de amostras constituídas por 100 sementes ou 100 pares de folhas de plântulas. As reações de amplificação foram conduzidas via reação da polimerase em cadeia e o programa de amplificação utilizado foi específico para microssatélites. Para a resolução dos fragmentos utilizaram-se os géis de agarose (3,5\%) e poliacrilamida (6\%). Com a finalidade de verificar a sensibilidade dos microssatélites em detectar a ocorrência de contaminantes, foram realizadas misturas sucessivas do DNA da linhagem denominada contaminante em DNA da linhagem pura, simulando níveis de contaminação de $0 \%, 0,01 \%, 0,013 \%, 0,02 \%, 0,04 \%, 0,1 \%, 0,2 \%, 1 \%, 2 \%, 5 \%$, $10 \%$ e $100 \%$. Foi observado que as características morfológicas de sementes, plântulas ou mesmo plantas, não ofereceram segurança suficiente para a detecção de contaminação em amostras de linhagens de milho. Por outro lado, a técnica de microssatélites apresentou maior eficiência e precisão, permitindo a detecção de níveis de contaminação de até 1\%, como o uso de amostras constituídas por sementes e também folhas de plântulas. No experimento simulando misturas com DNA de diferentes genótipos ( L1 - L2 e L3 - L4), a técnica de microssatélites foi eficiente em detectar de maneira consistente concentrações de $0,1 \%$ da amostra contaminante. Assim, a determinação da pureza varietal em lotes de sementes de linhagens de milho é mais eficiente pela utilização de marcadores microssatélites em comparação aos marcadores morfológicos. 


\title{
DETERMINATION OF VARIETAL PURITY IN MAIZE SEED LOTS USING MORPHOLOGICAL AND MICROSATELLITES MARKERS
}

\author{
Author: NILZA PATRÍCIA RAMOS \\ Adviser: Prof. Dr. JULIO MARCOS FILHO \\ Co-adviser: Prof. Dr. LUIS EDUARDO ARANHA CAMARGO
}

\section{SUMMARY}

Maize inbred lines seed production has been conducted to avoid the presence of varietal contamination since it compromises the subsequent multiplication phases within the commercial seed program. Contaminant seeds are detected through varietal and/or genetic purity determination tests which are usually based on morphological and biochemical markers, depending on the desired effectiveness. Thus, more efficient alternative approaches have been tested, with special emphasis on those based on DNA polymorphism. In that context, the main objective of this research was to compare the efficiency of morphological and microsatellite markers to evaluate varietal purity of maize inbred lines and to determine the sensitiveness of the microsatellite technique to detect the occurrence of contaminant genotypes in seed lots. There were used four inbred lines (L1, L2, L3 and L4) supplied by Dow AgroSciences Ltd., mixed to attain contamination 
levels of 0, 1, 2, 5, 10 and 100\%. L1 and L3 were considered pure strains while L2 and L4 were treated as contaminant genotypes. For the morphological marker evaluation seed, seedling and plant descriptors at different development stages were used. Specific maize primers were used in the microsatellite technique and the DNA was isolated from samples of 100 seeds or 100 pairs of seedling leaves. The DNA amplification reactions were conducted through polymerase chain reaction, with amplification program especially designed for microsatellites, and for fragments resolution, 3.5\% agarose and $6 \%$ polyacrilamyde gels were used. Successive mixtures among DNA of contaminant line and pure line $(0 \%, 0.01 \%$, $0.013 \%, 0.02 \%, 0.04 \%, 0.1 \%, 0.2 \%, 1 \%, 2 \%, 5 \%, 10 \%$, and $100 \%)$ were performed to simulate contamination levels with the objective of verify the microssatellite sensitiveness in detecting the occurrence of contaminants. Morphological characteristics of the seeds, seedlings or plants were less reliable to detect contamination in maize inbred lines than the microsatellite technique; this provides more efficient and accurate evaluation of varietal purity of seed lots. Levels with $1 \%$ of contamination were detected by the use of seed and seedling leaf samples. The experiment with mixtures of DNA (L1 - L2 and L3 - L4) using microsatellite technique allowed the consistent detection of $0.1 \%$ contaminant DNA concentration. Thus, the determination of varietal purity in maize seed lots is more efficient by using microsatellite markers than morphological markers. 


\section{INTRODUÇÃO}

O Brasil é o terceiro maior produtor mundial de milho, tendo produzido 46,7 milhões de toneladas em 2003 (FAO, 2004). Desse montante, 2\% corresponde a sementes (Santos et al., 2003), com predominância da participação de empresas nesse mercado. Os atributos genéticos, físicos, fisiológicos e de sanidade compõem a qualidade das sementes e interferem em seu potencial de desempenho (Marcos Filho, 1999), justificando-se a adoção de programa de controle de qualidade envolvendo todas as etapas de produção. $O$ componente genético merece atenção especial para assegurar que as características selecionadas pelos melhoristas sejam transferidas para 0 produtor rural.

A garantia da pureza genética é primordial em uma empresa produtora de sementes, com destaque para sementes de milho. Deve ser considerado que a pureza genética, atributo de sementes individuais, pode ser afetada durante a produção, provocada principalmente por polinizações não controladas. A determinação da pureza genética é complexa, pois frequentemente as contaminações não provocam elevadas alterações fenotipicas, especialmente em plantas de polinização cruzada.

Por outro lado, a pureza varietal é uma característica de um lote de sementes. A presença de sementes de outros cultivares em um lote acarreta a perda de sua pureza varietal. Isso ocorre, por exemplo, mediante a permanência de sementes em máquinas e instalações para semeadura, colheita, secagem, beneficiamento, transporte e armazenamento. Na classe de 
sementes básicas de milho a presença de sementes de outros genótipos não é tolerada, tendo em vista que os prejuízos causados a posteriori, com a multiplicação destas, ampliam consideravelmente os níveis de contaminação nas classes subsequentes.

A análise da pureza varietal, como rotina em laboratórios de sementes, é indispensável, pois podem ocorrer falhas no programa de controle de qualidade. Através dessa avaliação, pode-se determinar a presença de misturas de sementes na amostra e a porcentagem de sua ocorrência. Para tanto, podem ser usados descritores morfológicos, fisiológicos, citológicos e bioquímicos (AOSA, 1991, Brasil, 1992 e ISTA, 1996).

Nos programas brasileiros de controle de qualidade, a pureza genética e varietal de sementes de milho é geralmente é avaliada por meio de marcadores morfológicos de sementes, plântulas e plantas adultas. No entanto, essas análises podem ser ineficientes para distinguir genótipos morfologicamente semelhantes, devido à baixa precisão e à possível influência do ambiente. $\mathrm{O}$ uso de isoenzimas e, atualmente, de tecnologias baseadas em polimorfismo na molécula de DNA têm merecido destaque nesse tipo de avaliação. Marcadores moleculares isoenzimáticos, mesmo sendo mais eficientes que os morfológicos, podem se alterar com a deterioração das sementes e sob condições ambientais variadas; fazendo com que as técnicas baseadas no polimorfismo de DNA constituam opção mais consistente.

Entre os marcadores baseados em polimorfismo do DNA destacam-se os microssatélites (SSR). Estes constituem-se em alternativa promissora por se tratar de uma técnica relativamente simples, com resolução adequada em matriz de agarose, necessidade de pequena quantidade de DNA para análise e por não exigir conhecimento aprofundado de biologia molecular por parte do analista, nem instalações sofisticadas de laboratório. Desta maneira, pode ser adotada em programas de controle de qualidade realizados em laboratórios de pesquisa, estações experimentais de melhoramento genético e empresas produtoras de sementes (Smith \& Register III, 1998). 
Associada à técnica de microssatélites, a proposta de uso de DNA de amostras constituídas por várias sementes também representa uma inovação, uma vez que permite o rápido isolamento do DNA e a avaliação simultânea de vários lotes, acelerando a obtenção de resultados e a decisão quanto ao destino das sementes. Atualmente, as análises envolvendo marcadores moleculares na área de produção e tecnologia de sementes são realizadas principalmente em amostras de plântulas. Neste caso, é necessário promover a germinação das sementes, o que representa gasto adicional de tempo e possibilidade de insucesso no exame de sementes não viáveis, como ocorre freqüentemente em oleaginosas.

Considerando-se a importância da pureza genética e varietal em lotes de sementes básicas e do potencial de uso dos marcadores micossatélites, o presente trabalho teve como objetivos: a) avaliar a eficiência de marcadores morfológicos na determinação da pureza varietal de lotes de linhagens de milho, b) determinar o grau de sensibilidade da técnica de microssatélites para detectar a ocorrência de genótipos contaminantes em lotes de sementes, através da análise de sementes e de amostras foliares e c) comparar a eficiência dos marcadores morfológicos com os marcadores moleculares microssatélites, na determinação da pureza varietal de lotes de linhagens de milho. 


\section{REVISÃO DE LITERATURA}

O sucesso da organização de um sistema de produção de sementes depende diretamente da disponibilidade de quantidade adequada de sementes genéticas e básicas. As sementes básicas resultantes da multiplicação da semente genética ou da própria básica (Brasil, 2003) representam o "elo vital" entre a semente genética, produzida sob a responsabilidade do melhorista, e a semente a ser disponibilizada para o comércio (Carvalho \& Nakagawa, 2000). Por esse motivo, sua produção merece cuidados especiais para a manutenção da identidade genética e demais atributos que caracterizam a qualidade das sementes.

A contaminação varietal decorrente de misturas mecânicas, ocorridas na semeadura, na colheita, na recepção, no beneficiamento e no armazenamento, é mais facilmente controlada nas gerações subsequentes, se forem realizadas inspeções de campo, "roguing" e operações de limpeza de máquinas e equipamentos, com cautela e eficácia. Ao mesmo tempo, a mistura resultante de cruzamento natural indesejado aumenta com a multiplicação das sementes se o controle em campo for ineficiente. Por outro lado, a contribuição da mutação para a elevação da mistura varietal no lote é reduzida, pois as taxas de mutação em espécies exploradas economicamente são insignificantes (Andreoli, 1992).

$\mathrm{Na}$ classe de sementes básicas de milho os padrões estabelecidos pela Coordenadoria de Assistência Técnica Integrada (CATI, 1999) não permitem a presença de sementes de outros cultivares, contaminando lotes de sementes, 
pois isso implicaria em aumento dos níveis de contaminação nas classes subsequentes. Assim, misturas de sementes em lotes de linhagens podem acarretar prejuízos elevados, comprometendo a produção de híbridos. Medidas rigorosas são empregadas para manter a pureza varietal; entretanto, podem ocorrer falhas de controle que deverão ser detectadas através de testes que avaliem a presença de genótipos estranhos na amostra, bem como a porcentagem de sua incidência (Carvalho, 2000).

Os testes para a determinação da pureza varietal devem ser rápidos, de fácil execução, baixo custo e reproduzíveis dentro e entre laboratórios (Smith \& Register III, 1998). Entre os testes disponíveis encontram-se os baseados em marcadores morfológicos, que são pouco complexos, porém demorados e variáveis de acordo com condições ambientais, e aqueles baseados em marcadores moleculares (bioquímicos e polimorfismo de DNA), que são rápidos, mas exigem mão de obra especializada. O uso de testes baseados em marcadores morfológicos e bioquímicos ainda predomina (AOSA, 1991, Brasil, 1992 e ISTA, 1996) em comparação aos baseados em polimorfismo de DNA, mas esse panorama está se modificando.

\subsection{Marcadores morfológicos para análise de pureza varietal}

Marcadores são características capazes de identificar diferenças entre indivíduos e, do ponto de vista genético, devem ser herdáveis e de fácil avaliação (Ramalho et al., 1990). Assim, marcadores morfológicos são características fenotípicas de variação discreta, ou seja, expressam-se na semente, em plântulas ou plantas adultas (Paukens, 1975). Portanto, testes que utilizam esses marcadores exigem, muitas vezes, a condução do ciclo completo da cultura para a observação de características morfológicas que diferenciem os genótipos, além de extensa área experimental, tempo para a condução da cultura e mão de obra qualificada (Smith \& Register III, 1998). 
A grande limitação dos marcadores morfológicos é a sua ocorrência em número reduzido e, consequentemente, insuficiente para marcar alelos de interesse de vários genes da espécie (Ramalho et al., 1990). A observação do fenótipo muitas vezes não oferece informações a respeito dos atributos genéticos, como os relacionados à qualidade dos grãos que influem na concentração de óleo e proteína ou na resistência a estresses bióticos e abióticos incorporados aos cultivares (Menezes et al., 2002). Dessa forma, distinguir cultivares morfologicamente semelhantes, mas diferentes nessas características pode não ser possível

Quando as diferenças morfológicas são facilmente visualizadas, como a distinção de sementes através da observação da cor do endosperma ou do pericarpo, a verificação da presença de sementes contaminantes é mais rápida, com possibilidade de remoção do genótipo indesejável durante o beneficiamento, como por exemplo, através do uso de equipamentos eletrônicos que separam pela cor (Wyck, 1988). Isso resulta em controle mais eficiente da qualidade do lote de sementes. Entretanto, McDonald et al. (1995) relataram que os resultados obtidos pela avaliação de características físicas das sementes podem ser deficientes e até imprecisos, pois o estresse ambiental ou as operações pós-colheita podem alterar aspectos morfológicos específicos, prejudicando a confiabilidade do teste.

Alguns cultivares de soja apresentam variação na cor do hilo da semente, causada por alterações no ambiente em que são produzidas, como a ocorrência de veranicos e de temperaturas elevadas, durante a fase de maturação, sem que haja variação genética entre as sementes. A alteração na tonalidade da cor do hilo pode levar ao descarte de lotes de sementes de elevado padrão pela impossibilidade de comprovar a pureza varietal (Moreira et al, 1999). Portanto, o uso de marcadores morfológicos para determinar pureza varietal em lotes de sementes de soja deve ser feito com cautela, pois podem conduzir a resultados pouco confiáveis. 
As regras para análise sementes da Association of Official Seed Analysts (AOSA, 1983) sugerem que a observação de características morfológicas de plântulas e plantas em crescimento deve ser utilizada quando as características físicas das sementes não permitirem identificá-las e diferenciá-las entre si, com segurança. A possibilidade de avaliação de características de plântula até a maturidade da planta apresenta-se como vantagem no uso de marcadores morfológicos (Payne, 1986), pois permite diferenciar genótipos com maior segurança, uma vez que várias características são observadas. Dentre essas, destacam-se a forma da folha, a altura da planta, o ângulo de inserção da folha e da espiga, a pigmentação com antocianina em diferentes partes da planta, entre outros (Pauksens, 1975; Pauksens \& Dhsei, 1978). Vale ressaltar que a avaliação de características morfológicas de plântulas e de plantas adultas pode ser considerada uma vantagem no caso de identificação de cultivares, mas uma desvantagem para a análise de pureza varietal. Uma vez que, esperar até estádios avançados da maturidade para identificar contaminações em lotes de sementes (Smith \& Register III, 1998) pode atrasar as decisões sobre o destino dos lotes.

As características morfológicas podem variar com o ambiente, reduzindo a precisão dos resultados da análise da pureza genética e varietal (Ditmer, 1979; Schimidt, 1979 e Cooke, 1984). A interação entre genótipo e ambiente pode levar à variação na intensidade da pigmentação de antocianina e da sua distribuição nas partes da planta, a alteração na intensidade da coloração da folha e estiolamento da plântula, devido à ausência de luminosidade durante a condução do teste, que induzem à descaracterização do fenótipo e dificultam a sua comparação com padrões de referência. Revila \& Tracy (1995), trabalhando com cerca de 34 características morfológicas de milho doce, observaram que apenas 19 mantiveram-se estáveis em dois períodos de semeadura. Porém, outros marcadores morfológicos apresentaram pouca interação ambiental e podem, de acordo com Goodman \& Paterniani (1969), ser utilizados com maior segurança. Esses autores sugerem ainda, que a seleção de descritores 
morfológicos deve ser baseada em avaliações fenotípicas realizadas sob diferentes condições ambientais.

O uso de características como a cor do estilo-estigma, da antera e do grão foram apontadas como sendo de elevada repetibilidade, em avaliações conduzidas por vários anos em locais variados, podendo ser recomendadas para a identificação de cultivares (Smith \& Smith, 1989) e mostrando-se marcadores satisfatórios para avaliação de pureza varietal de genótipos de milho. Também, Von Pinho (1995) e Salgado (2001) identificaram de forma satisfatória a presença de plantas contaminantes em populações dos híbridos de milho C 701 e UFLA7/4, respectivamente, quando foi utilizada a coloração das antera e do estilo-estigma, baseada na pigmentação com antocianina.

O pigmento antocianina é um flavonóide de coloração púrpura e pode estar presente no coleóptilo, raiz primária, lígula, folha, colmo, estilo-estigma, gluma, antera, pericarpo e escutelo, entre outros tecidos. Entretanto, seu uso como marcador pode trazer problemas devido à elevada variação de intensidade, observada em diferentes estádios fenológicos e partes da planta (Srivastava \& Agrawa, 1985). A antocianina tem sua expressão controlada por um grande número de genes e durante o processo de melhoramento pode ocorrer segregação ou variabilidade de expressão que dificultam o seu uso em análises de pureza genética (Singh \& Sarkar, 1982).

A escolha do marcador mais eficiente para diferenciar cultivares em análises de pureza varietal pode variar com o genótipo. Assim, o estádio de desenvolvimento a ser avaliado depende da possibilidade de identificar, com segurança, as características de interesse. Depende também, da rapidez necessária para obtenção dos resultados a serem empregados nas decisões a respeito do destino do lote ou mesmo para a aferição do trabalho de despendoamento nos campos de produção, no caso de híbridos (Von Pinho et al., 1997).

Trabalho conduzido por Payne (1986) demonstrou que características morfológicas de sementes, plântulas e plantas eram utilizadas por cerca de 
$50 \%$ dos laboratórios filiados à AOSA, para análise de pureza varietal de milho. Vários genótipos, porém, são difíceis de serem diferenciados e exigem técnicas mais apuradas de caracterização, como as baseadas em proteínas, isoenzimas e polimorfismo de DNA (Carvalho, 2000).

Avaliando a pureza genética e varietal de lotes de sementes de feijão, Vieira et al. (2001) observaram que materiais morfologicamente semelhantes apresentam baixa precisão em análise de pureza varietal, quando esta se baseava em características morfológicas, além dessas se alterarem com variações ambientais. Também, Meesang et al. (2001) analisando sementes de soja, afirmaram que a exigência por técnicas mais precisas deve-se ao aumento da quantidade de novos cultivares que são lançados no mercado a cada ano. Esses genótipos apresentam, freqüentemente, elevada similaridade fenotípica, diferenciando-se apenas por grupos de genes ligados à resistência a doenças, a herbicidas ou pragas e adaptação a condições climáticas específicas. Portanto, a possibilidade de avaliação através de marcadores morfológicos é reduzida, prejudicando a confiabilidade nos resultados obtidos nesses testes.

O uso de marcadores moleculares é, portanto, uma alternativa eficaz para a análise de pureza tanto genética como varietal em lotes de sementes, apresentando vantagens como maior precisão, possibilidade de diferenciar indivíduos morfologicamente semelhantes, gasto reduzido de tempo e, principalmente, rapidez e confiança na obtenção de resultados.

\subsection{Marcadores moleculares para análise de pureza varietal}

Marcadores moleculares são definidos como todo fenótipo molecular originário de um gene expresso como isoenzimas ou de um segmento específico de DNA que pode ou não corresponder à regiões expressas do genoma. Podem ser utilizadas para identificação de genótipos, avaliações de

germoplasmas, mapeamento genético (Ferreira \& Grattapaglia, 1998) e também com potencial para análises de pureza genética e varietal em lotes de sementes 
(McDonald et al., 1994; Rongewen et al., 1995; Smith \& Register III, 1998; Carvalho, 2000; Meesang et al., 2001 e Vieira et al., 2001).

Entre as primeiras técnicas moleculares estudadas, encontram-se as baseadas em proteínas e isoenzimas. Proteínas podem ser usadas como marcadores para os genes que as codificam (Ferreira \& Grattapaglia, 1998). Diferenças na mobilidade das mesmas quando submetidas a um campo elétrico resultam das seqüências distintas de nucleotídeos que codificam tais proteínas; logo, assume-se que diferenças nos padrões eletroforéticos das proteínas possuem base genética e são herdáveis (Murphy et al., 1990), podendo ser empregadas com sucesso na certificação de pureza genética (Cooke, 1995). A AOSA (1991) recomenda a técnica de eletroforese de isoenzimas para a cultura do milho, sugerindo vários sistemas isoenzimáticos, como o da álcool desidrogenase, malato desidrogenase, esterase, fosfatase ácida e glutamatooxalacetato transaminase. Porém, Pierce \& Brewbaker (1973) observaram que a estabilidade das isoenzimas presentes nos diversos tecidos vegetais varia quando estes são submetidos à condições ambientais distintas, como alteração de temperatura, fotoperíodo, nutrição mineral, injúria mecânica e associação com microrganismos, comprometendo os resultados.

Comparando a eficiência e reprodutibilidade entre as técnicas baseadas em marcadores morfológicos e isoenzimáticos na detecção de contaminações em linhagens de milho, Orman et al. (1991) observaram que as análises de isoenzimas apresentaram elevada precisão, mas os resultados mais interessantes e satisfatórios foram obtidos com a associação das técnicas. Mesmo com vantagens em relação aos marcadores morfológicos, a técnica de eletroforese de proteínas e isoenzimas apresenta inconvenientes, como alteração de comportamento devido à variações no ambiente, no potencial fisiológico e da sanidade das sementes (Carvalho, 2000). Como alternativa, foi proposto o uso de técnicas baseadas em polimorfismo de DNA, que praticamente não se alteram com o ambiente, nem mesmo com a presença de microrganismos e permitem uma análise mais precisa e objetiva. 
As técnicas envolvendo DNA apresentam alto poder de resolução, com as diferenças entre os indivíduos detectadas nas seqüências de nucleotídeos distribuídas pelo genoma (Ferreira \& Grattapaglia, 1998), que permitem a distinção entre genótipos com elevada facilidade. Entre as técnicas disponíveis, as baseadas na reação da polimerase em cadeia (PCR) oferecem vantagens em relação a outros métodos, pois utilizam reduzidas quantidades de DNA e os perfis eletroforéticos são obtidos com maior rapidez (Ferreira \& Grattapaglia, 1998 e Guimarães, 1999).

O uso da enzima termoestável Thermus aquaticus (Taq) DNA polimerase é a base da técnica de PCR, utilizada para vários marcadores, como RAPD ou DNA amplificado ao acaso (Williams et al., 1990; Welsh \& McClelland, 1990), AFLP ou polimorfismo de comprimento de fragmento amplificado (Vos et al., 1995) e marcadores microssatélites ou seqüências simples repetidas (SSR) (Morgante \& Olivieri, 1993). Esses marcadores têm conduzido as pesquisas de identificação de cultivares em direção a uma nova geração de testes para análise da pureza genética e varietal.

Marcadores RAPD destacam-se pelo custo reduzido e facilidade de obtenção de resultados. Porém, apresentam baixa repetibilidade dos resultados entre e dentro dos laboratórios, resultante da falta de especificidade dos iniciadores utilizados nas reações de amplificação (Riedy et al., 1992; Heun \& Helentjaris, 1993), que os tornam inconvenientes par o uso em testes de rotina. Também o caráter dominante compromete a precisão desse marcador para as análises de pureza. Dominância, nesse caso, não se refere ao conceito clássico de interação gênica entre alelos de um mesmo loco, mas sim da visualização dos fragmentos amplificados, observados no gel. Portanto, não é possível distinguir se o segmento observado foi originado a partir de uma ou duas sequências amplificadas, para o caso de indivíduos heterozigotos (Ferreira \& Grattapaglia, 1998).

Os marcadores AFLP, assim como os RAPD, apresentam problemas relacionados à não identificação da região onde o marcador é detectado e a 
impossibilidade de identificação de indivíduos heterozigotos, em função de seu caráter dominante. Enquanto, os microssatélites possuem caráter codominante, com ambos os alelos de indivíduos heterozigotos visualizados em gel de eletroforese. Essa característica associada ao seu elevado polimorfismo tornam-nos interessantes para o uso em avaliações de cultivares e análises de pureza genética e varietal, sem comprometimento da precisão dos resultados.

Marcadores microssatélites encontram-se amplamente distribuídos no genoma de organismos eucariotos (Hearne et al., 1992 e Gupta et al., 1996) e podem ser definidos como segmentos curtos de DNA (motivos) que se repetem sucessivamente, ladeados por seqüências únicas e conservadas ( $\mathrm{Yu}$ et al., 1994). Os segmentos são constituídos por seqüências contendo 2 a 10 nucleotídeos, repetidas de 5 a 50 vezes, sendo que, em alguns casos, podem chegar a centenas de vezes (Morgante \& Olivieri, 1993; Chin et al, 1996 e Senior et al., 1996). O número de repetições é que vai determinar o comprimento dos fragmentos a serem amplificados. Portanto, o polimorfismo é detectado por diferenças no comprimento dos fragmentos (Tautz, 1989; Ferreira \& Grattapaglia, 1998).

Para a cultura do milho, a freqüência média é de uma região microssatélite a cada 50 mil pares de bases (Chin et al., 1996; Morgante \& Olivieri, 1993), tornando as seqüências passíveis de serem utilizadas como marcadores moleculares, pois cobrem amplamente o genoma dos indivíduos. A técnica para a detecção dessas regiões consiste em amplificar, via PCR, as regiões microssatélites, utilizando pares de iniciadores ("primers") específicos (20-30 bases) e complementares às seqüências únicas que as flanqueiam (Chin et al., 1996). A detecção de sequências microssatélites é feita em gel de eletroforese, utilizando-se poliacrilamida ou agarose especial de alta resolução, uma vez que a separação de fragmentos que diferem por poucos pares de bases, exige um gel com elevada resolução. A visualização pode ser feita diretamente por coloração com brometo de etídio ou nitrato de prata (Ferreira \& Grattapaglia, 1998). 
Uma desvantagem dos marcadores microssatélites é a homologia dos locos microssatélites ser baseada no tamanho dos produtos gerados, o que pode apresentar problemas de interpretação. Fragmentos representativos de locos distintos podem ocupar a mesma posição no gel, em função da similaridade no número de bases desses fragmentos. A necessidade de desenvolvimento de iniciadores específicos que flanqueiam as regiões microssatélites e a exigência da construção de bibliotecas genômicas enriquecidas com microssatélites, clonagem e sequenciamento, também pode ser considerado um entrave para a adoção rápida desses marcadores (Ferreira \& Grattapaglia, 1998 e Carvalho, 2000). Entretanto, uma vez desenvolvidos os iniciadores, a geração de marcadores torna-se fácil e rápida. Lanza et al. (2000) observaram que, com o aumento da disponibilidade de iniciadores de microssatélites para várias espécies, o uso desta técnica pode se tornar cada vez mais acessível. Para milho, isso não representa um problema, pois encontram-se disponíveis em torno de 1.400 iniciadores microssatélites, cuja sequência e posição no genoma podem ser observadas no banco de "primers" para milho (Research Genetics - EUA - www.agron.missouri.edu).

O uso dos marcadores microssatélites em plantas já foi descrito para identificação de cultivares, mapeamento genético e até mesmo para determinação de pureza genética, para várias espécies. São encontrados na literatura trabalhos com soja (Rongwen et al., 1995; Diwan \& Cregan, 1997), arroz (Olufowote et al., 1997), batata (Schneider \& Douches, 1997), cevada (Russel et al., 1997), eucalipto (Kirst, 1999) e milho (Taramino \& Tingey, 1996; Senior \& Heun, 1993; Phelps et al., 1996), entre outras espécies.

Meesang et al., (2001) além de utilizarem com sucesso marcadores microssatélites para destinguir dois genótipos de soja (SJ4 e SJ5) morfologicamente semelhantes e geneticamente próximos, utilizaram essas marcas para determinar o grau de homogeneidade genética de cada cultivar. Também, Schuster et al. (2000) e Schuster et al. (2004) obtiveram sucesso na 
identificação de pureza varietal em lotes de sementes de soja utilizando esses marcadores.

A pureza varietal em sementes de milho híbrido foi verificada com eficiência por Salgado (2001), que confirmou a possibilidade de separação de sementes provenientes do parental feminino autofecundado das sementes híbridas do lote. Nesse trabalho, o uso de marcadores morfológicos também permitiu a detecção de misturas de sementes no lote, sendo que a emergência das plântulas se fez necessária para a observação das características morfológicas. Porém, nem todas as sementes contaminantes foram detectadas e o tempo para a obtenção dos resultados foi significativamente superior ao necessário para a análise através de microssatélites.

O uso de microssatélites é portanto de elevado interesse, devendo ser pesquisado e explorado em análises de pureza varietal e genética, pois trata-se de uma técnica simples, que não exige quantidade elevada de DNA, nem conhecimento avançado em biologia molecular por parte dos técnicos. As instalações laboratoriais não necessitam ser sofisticadas e a tecnologia pode ser facilmente transferida para laboratórios de pesquisa, estações experimentais de melhoramento e empresas privadas. Essas vantagens, associadas à possibilidade de utilização de amostras com DNA extraído de sementes, aumentam a possibilidade do uso desse marcador em testes de rotina de laboratórios de análises de sementes. Porém, pesquisas que utilizam diretamente as sementes, como material para isolamento de DNA, são escassas.

A possibilidade de uso de tecido de sementes para isolamento de DNA foi avaliada por Benito et al. (1993), com a finalidade de identificar cultivares de cevada e centeio através de RAPD. Porém, os resultados obtidos não foram satisfatórios e o insucesso na amplificação foi atribuído à grande quantidade de impurezas associadas ao DNA extraído das sementes. Para verificar a consistência dessas informações, McDonald et al. (1994) realizaram um trabalho onde foram testados vários protocolos de isolamento de DNA, 
utilizando sementes de milho, algodão, soja, trigo, trevo vermelho e amendoim. Os resultados demonstraram que tanto a qualidade como a quantidade do DNA extraído de sementes de quase todas as espécies estudadas foram satisfatórias para análises RAPD. A exceção foi em amendoim que, por conter grande quantidade de óleo, forneceu DNA de pior qualidade e em baixa quantidade.

Chunwongse et al. (1993) observaram que o produto amplificado pela PCR foi idêntico entre amostras cujo DNA foi extraído a partir de tecido das sementes e das folhas de plântulas, para as culturas do arroz e do trigo. Para o milho, no entanto, os resultados não foram satisfatórios, pois a elevada quantidade de amido prejudicou a reação de PCR, em função das impurezas presentes. Esses autores ressaltaram ainda que o uso de tecidos de plântulas é menos vantajoso por exigir maior período de tempo para as avaliações.

Além da qualidade e quantidade do DNA extraído de sementes de milho, Zhang et al. (1996) verificaram os padrões de bandas obtidos a partir de diferentes partes da semente, como pericarpo, endosperma e embrião. Foi possível observar que para sementes híbridas, a verificação da identidade genética não pôde ser realizada em amostras de DNA extraído de pericarpo e endosperma, pois esses são tecidos de herança materna e podem prejudicar a verificação da identidade. Por outro lado, o DNA extraído do embrião é o mais recomendado e conduziu a resultados satisfatórios, pois a contribuição do DNA originado de cada um dos parentais é igual. Com relação à quantidade de DNA obtida, valores elevados foram obtidos dos tecidos do embrião, seguido do endosperma e pericarpo.

Marcos Filho et al. (1997) também obtiveram resultados consistentes utilizando DNA extraído de sementes de soja, mas observaram que a quantidade de DNA isolada poderia se alterar em função do estado deteriorativo das sementes. Conforme a semente foi envelhecida artificialmente, a concentração de DNA foi reduzida, porém os padrões de amplificação obtidos a partir de RAPD não se alteraram. 
Embora o uso de DNA isolado a partir de sementes leve a resultados consistentes; análises realizadas com sementes individuais podem se tornar um entrave de ordem prática, em função da exigência de grande número de sementes representativas da amostra. As RAS determinam o uso de quatro repetições de 100 sementes para a verificação de sementes de outros cultivares em um lote. Assim, em um teste de rotina, seriam necessárias extrações de DNA e amplificações em cada uma das 100 sementes de cada repetição, consumindo maior tempo de trabalho, além de gasto com reagentes utilizados para extração de DNA e amplificação através de PCR.

Poucos são os trabalhos encontrados na literatura abordando o uso de amostra constituída por várias sementes. Nesse contexto, Schuster et al. (2004) avaliaram a possibilidade de uso de DNA isolado a partir de um "pool" de sementes de soja. Como resultado, observaram que amostras compostas por DNA extraído de 5 a 8 sementes amplificaram satisfatoriamente as regiões microssatélites, identificando a presença de misturas entre os cultivares.

Mesmo não sendo trabalhos que abordem diretamente a possibilidade de uso de várias sementes em uma amostra a ser amplificada via PCR, ensaios com simulação de níveis de contaminação do DNA molde em reações RAPD podem servir como ponto de partida. Nesse sentido, Staub et al. (1996), simulando contaminação de amostras constituídas pela linhagem PI432860 de pepino com DNA extraído da linhagem G421, nas proporções de 1:1, 10:1, $20: 1,50: 1,100: 1,1.000: 1,10.000: 1$ e 20.000:1, observaram que foi possível detectar a presença de bandas características da linhagem contaminante até a proporção 20:1, o que corresponderia a 5\%. Se for considerado que na técnica de microssatélites são utilizados iniciadores específicos, a possibilidade de detecção de DNA em proporções ainda menores é teoricamente superior.

Experimento semelhante foi realizado por Zhang et al. (1996) com os cultivares de soja Thorne e Vickery. Misturas de DNA, de ambas as linhagens foram realizadas em concentrações de 10\% a 100\%, sendo Vickery considerado contaminante da amostra. Com base nos resultados pôde se 
observar a amplificação do DNA molde de ambos os cultivares até $10 \%$ de concentração do contaminante. Além da presença da banda característica do cultivar Vickery, os autores verificaram o aumento na intensidade dessa banda conforme a concentração do DNA foi aumentando na diluição. Horejsi et al. (1999) também trabalharam com simulação de contaminação interpopulacional através de diluições de DNA dos cultivares G421 e H19 nas concentrações de $0 \%, 1 \%, 2 \%, 3 \%, 5 \%, 10 \%, 90 \%, 95 \%, 97 \%, 98 \%, 99 \%$ e $100 \%$ e observaram que níveis de até $1 \%$ de contaminação foram detectados tanto para marcadores RAPD como para SCAR (Seqüência Caracterizada de Região Amplificada), sendo que houve diferença na eficiência de detecção em função dos "primers" testados. Portanto, houve "primers" que permitiram detectar a presença de DNA contaminante somente em níveis superiores ou iguais a $10 \%$.

Diante do exposto, pesquisas que visem aprimorar a técnica de microssatélites para a análise de rotina de pureza varietal são relevantes, assim como o uso de várias sementes em uma mesma amostra para extração de DNA vegetal. Essas técnicas associadas podem agilizar a tomada de decisões, dentro do sistema de produção de sementes, considerando-se que não é tolerada a presença de sementes de outros cultivares, em lotes de sementes de linhagens de milho. Contaminações com outros cultivares alteram a qualidade do lote e reduzem os benefícios genéticos alcançados pelos melhoristas Neste contexto, a confirmação da possibilidade de uso desta técnica molecular atinge diretamente o interesse do setor produtivo, pois as empresas produtoras de sementes estão, permanentemente, voltadas à adoção de procedimentos simples, precisos e eficientes. 


\section{MATERIAL E MÉTODOS}

O presente trabalho foi conduzido nos laboratórios de Análise de Sementes e de Genética Molecular, dos Departamentos de Produção Vegetal e de Entomologia, Fitopatologia e Zoologia Agrícola, respectivamente, ambos pertencentes à Escola Superior de Agricultura "Luiz de Queiroz", USP, em Piracicaba/SP. Parte da pesquisa foi realizada nos campos experimentais da empresa Dow AgroSciences Ltda, localizada em Cravinhos/SP e da USP ESALQ, localizada em Piracicaba/SP.

Com a finalidade de simular diferentes níveis de contaminação varietal em lotes de sementes de linhagens de milho, foram utilizadas quatro linhagens (L1, L2, L3 e L4) cedidas pela empresa de sementes Dow AgroSciences Ltda., misturadas entre si duas a duas, constituindo cada mistura um ensaio. Desta forma, para o ensaio denominado A, sub-amostras de 100 sementes de L1 e L2 foram misturadas, em proporções variáveis (100:0, 99:1, 98:2, 95:5, 90:10 e 0:100), para a obtenção de amostras com 0 a 100\% de contaminação. Misturas entre L3 e L4 também foram realizadas, respeitando os mesmos níveis de contaminação do ensaio anterior. Este segundo ensaio foi denominado B. As linhagens padrões ou puras nas amostras foram L1 e L3, enquanto L2 e L4 foram tratadas como contaminantes dos lotes. A descrição dos seis tratamentos avaliados em cada ensaio encontra-se na Tabela 1. 
Tabela 1. Descrição dos tratamentos representados por diferentes níveis de misturas de linhagens de milho, onde sementes de L2 foram misturadas a amostras de L1 (ensaio A) e, de L4, misturadas a amostras de L3 (ensaio B)

\begin{tabular}{lcccc}
\hline \multicolumn{2}{c}{ Ensaio A } & & \multicolumn{2}{c}{ Ensaio B } \\
\cline { 2 - 2 } \cline { 5 - 5 } Tratamento & Descrição & & Tratamento & Descrição \\
\hline T1 & 100\% L1 + 0\% L2 & & T7 & $100 \%$ L3 + 0\% L4 \\
T2 & $99 \%$ L1 + 1\% L2 & & T8 & $99 \%$ L3 + 1\% L4 \\
T3 & $98 \%$ L1 + 2\% L2 & & T9 & $98 \%$ L3 + 2\% L4 \\
T4 & $95 \%$ L1 + 5\% L2 & & T10 & $95 \%$ L3 + 5\% L4 \\
T5 & $90 \%$ L1 + 10\% L2 & & T11 & $90 \%$ L3 + 10\% L4 \\
T6 & 0\%L1 + 100\% L2 & & T12 & $0 \% \mathrm{~L} 3+100 \%$ L4 \\
\hline
\end{tabular}

\subsection{Caracterização preliminar}

As sementes das quatro linhagens, utilizadas neste estudo, foram caracterizadas previamente quanto aos atributos físicos, fisiológicos e de sanidade. Essa caracterização teve a finalidade de detectar possíveis causas de desenvolvimento desigual de plântulas e plantas. As alterações poderiam ocorrer devido à diferenças entre genótipos, potencial fisiológico ou sanidade das sementes.

Para a determinação dos atributos físicos e fisiológicos foram realizados os testes a saber:

i) teor de água - realizado com duas subamostras de cinco gramas de sementes para cada lote, pelo método da estufa a $105^{\circ} \mathrm{C} \pm 3^{\circ} \mathrm{C}$, durante 24 horas (Brasil, 1992). Os resultados foram expressos em porcentagem (base úmida);

ii) germinação - realizada em oito repetições de 50 sementes distribuídas em rolo de papel, umedecido com volume de água na proporção de duas 
vezes e meia o seu peso seco. Após a semeadura, os rolos foram acondicionados em germinador sob temperatura constante de $25^{\circ} \mathrm{C}$ e umidade relativa próxima a $100 \%$. A avaliação da porcentagem de sementes que originaram plântulas normais foi realizada aos sete dias após a semeadura (Brasil, 1992);

iii) primeira contagem de germinação - foi determinada mediante a avaliação da porcentagem de sementes que originaram plântulas normais no quarto dia após a semeadura do teste de germinação (Nakagawa, 1999);

iv) teste de frio - conduzido de acordo com Caseiro \& Marcos Filho (2002), utilizando quatro repetições de 50 sementes distribuídas em substrato constituído por $2 \mathrm{~kg}$ da mistura areia e terra (3:1), umedecido até $60 \%$ de sua capacidade de retenção, com água previamente resfriada a $10^{\circ} \mathrm{C}$, sendo mantido em bandejas plásticas (34 × $23 \times 7 \mathrm{~cm})$. Para reduzir a evaporação, essas bandejas foram mantidas no interior de sacos plásticos e, posteriormente, transferidas para câmara fria a $10^{\circ} \mathrm{C}$ por sete dias. Vencido este período, as bandejas foram colocadas em câmara de germinação a $25^{\circ} \mathrm{C}$ por mais sete dias, quando determinaram-se as percentagens de plântulas normais;

v) teste de envelhecimento acelerado - conduzido segundo Hampton \& Tekrony (1995) a $45^{\circ} \mathrm{C}$, durante 72 horas, seguido por teste de germinação com avaliação de plântulas normais no quarto dia, sendo os resultados expressos em porcentagem.

A análise da sanidade das sementes foi realizada com uma amostra de 200 sementes de cada linhagem, através do método do papel de filtro, com congelamento (Neergaard, 1979). Três folhas de papel de filtro, embebidas em água destilada, foram colocadas em placas de Petri, onde distribuíram-se 10 sementes eqüidistantes. A incubação foi efetuada em câmara a $20 \pm 2^{\circ} \mathrm{C}$, com fotoperíodo de $12 \mathrm{~h}$. Em seguida, as amostras foram transferidas para congelador a $5^{\circ} \mathrm{C}$ por $24 \mathrm{~h}$, para evitar a germinação das sementes. Após este período, as sementes foram incubadas por cinco dias sob as mesmas 
condições da incubação anterior, sendo posteriormente identificados os microrganismos presentes. A avaliação foi realizada com auxilio de microscópio estereoscópico e, quando necessário, a identificação das estruturas deu-se em microscópio composto. Os resultados foram expressos em porcentagem de cada patógeno presente nas sementes.

\subsection{Marcadores morfológicos}

Para a avaliação da pureza varietal dos lotes de sementes de linhagem de milho utilizando marcadores morfológicos, foram realizadas avaliações utilizando características morfológicas observadas em sementes, plântulas e plantas em diferentes estádios de desenvolvimento. A escolha dos marcadores foi baseada nos descritores mínimos do milho, exigidos pelo Ministério da Agricultura Pecuária e Abastecimento para o registro nacional e proteção de cultivares (Brasil, 1997) e disponível no endereço: www.agricultura.gov.br.

\subsubsection{Avaliação de sementes}

Quatro repetições de 100 sementes de cada tratamento foram distribuídas sobre uma superfície clara (papel cartolina de cor branca) sob luz natural, onde procedeu-se a avaliação das características morfológicas descritas no Quadro 1. Três avaliadores analisaram, individualmente, cada tratamento e os resultados médios foram expressos em porcentagem de sementes com características que diferiram das linhagens convencionadas como puras (L1 e L3). 


\begin{tabular}{|l|c|c|c|c|}
\hline Características da semente & L1 & L2 & L3 & L4 \\
\hline Coloração do pericarpo & incolor & incolor & incolor & bronze \\
\hline Coloração do endosperma & branco & Amarelo & alaranjado & avermelhado \\
\hline Coloração da coroa & $\begin{array}{c}\text { amarela/ } \\
\text { alaranjada }\end{array}$ & Amarela & amarela & $\begin{array}{c}\text { vermelha/ } \\
\text { alaranjada }\end{array}$ \\
\hline $\begin{array}{l}\text { Textura e aspecto do } \\
\text { endosperma }\end{array}$ & semi-duro & Ceroso & $\begin{array}{c}\text { semi- } \\
\text { dentado }\end{array}$ & semi-duro \\
\hline
\end{tabular}

Quadro 1 - Descritores morfológicos utilizados na diferenciação de sementes das linhagens L1, L2, L3 e L4, de milho, baseados nos descritores mínimos exigidos para registro de cultivares (Brasil, 1997)

\subsubsection{Avaliação de plântulas}

As amostras representativas de cada tratamento tiveram suas sementes distribuídas, individualmente, em caixas plásticas contendo uma mistura de areia e solo na proporção 3:1, com irrigação até $60 \%$ da capacidade de retenção de água. Sete dias após a semeadura, as plântulas foram coletadas e lavadas em água corrente, sendo posteriormente colocadas em superfície clara, onde foi realizada a avaliação das características morfológicas descritas no Quadro 2. As avaliações das quatro repetições de cada tratamento foram feitas por três avaliadores e os resultados médios expressos em porcentagem de plântulas com características que diferiram das linhagens convencionadas como puras (L1 e L3).

Além da avaliação realizada mediante a observação de marcadores morfológicos de plântulas, procedeu-se a determinação do comprimento total e comprimento da parte aérea das plântulas. Neste procedimento, todas as plântulas de cada tratamento foram medidas individualmente, com auxílio de régua graduada, sendo os valores médios expressos em centímetros. Essa avaliação teve como objetivo determinar se, numericamente, seria possível identificar a presença de contaminantes nas amostras em análise. 


\begin{tabular}{|l|c|c|c|c|}
\hline Características da plântula & L1 & L2 & L3 & L4 \\
\hline $\begin{array}{l}\text { Pigmentação pela antocianina } \\
\text { no coleoptilo }\end{array}$ & ausente & $\begin{array}{c}\text { presente } \\
\text { (intensa) }\end{array}$ & ausente & $\begin{array}{c}\text { presente } \\
\text { (fraca) }\end{array}$ \\
\hline $\begin{array}{l}\text { Pigmentação pela antocianina } \\
\text { na bainha foliar }\end{array}$ & $\begin{array}{c}\text { presente } \\
\text { (fraca) }\end{array}$ & $\begin{array}{c}\text { presente } \\
\text { (intensa) }\end{array}$ & $\begin{array}{c}\text { presente } \\
\text { (fraca) }\end{array}$ & $\begin{array}{c}\text { presente } \\
\text { (intensa) }\end{array}$ \\
\hline $\begin{array}{l}\text { Pigmentação pela antocianina } \\
\text { na nervura central da folha }\end{array}$ & ausente & $\begin{array}{c}\text { presente } \\
\text { (fraca) }\end{array}$ & ausente & $\begin{array}{c}\text { presente } \\
\text { (fraca) }\end{array}$ \\
\hline $\begin{array}{l}\text { Pigmentação pela antocianina } \\
\text { na borda foliar }\end{array}$ & ausente & $\begin{array}{l}\text { presente } \\
\text { (intensa) }\end{array}$ & ausente & $\begin{array}{c}\text { presente } \\
\text { (fraca) }\end{array}$ \\
\hline $\begin{array}{l}\text { Intensidade de verde na 1a } \\
\text { folha verdadeira }\end{array}$ & escuro & médio & escuro & claro \\
\hline $\begin{array}{l}\text { Forma da extremidade da 1a } \\
\text { folha verdadeira }\end{array}$ & pontiaguda & arredondada & arredondada & $\begin{array}{l}\text { pontiaguda/ } \\
\text { arredondada }\end{array}$ \\
\hline
\end{tabular}

Quadro 2 - Descritores morfológicos utilizados na diferenciação de plântulas das linhagens L1, L2, L3 e L4, de milho, baseados nos descritores mínimos exigidos para registro de cultivares (Brasil, 1997)

\subsubsection{Avaliação de plantas em campo}

Foram conduzidos dois experimentos em campo, sendo o primeiro em área da estação experimental da empresa Dow AgroSciences Ltda., na cidade de Cravinhos - SP, no período de novembro a dezembro de 2002. A estação está localizada a 820 metros de altitude, com latitude $23^{\circ} \mathrm{S}$, no nordeste do Estado de São Paulo. A temperatura observada no período apresentou média de $25^{\circ} \mathrm{C}$, com máxima de $31^{\circ} \mathrm{C}$ e mínima de $19^{\circ} \mathrm{C}$. A precipitação média mensal foi de $265 \mathrm{~mm}$, com total de $521 \mathrm{~mm}$ no período. O segundo experimento foi conduzido em campo experimental do Departamento de Produção Vegetal da Escola Superior de Agricultura "Luiz de Queiroz", na cidade de Piracicaba - SP, no período de março a julho de 2003. A ESALQ está localizada a uma altitude de 546 metros, com latitude $22^{\circ} \mathrm{S}$, no oeste do Estado de São Paulo. A temperatura observada no período apresentou média de $20^{\circ} \mathrm{C}$, com máxima de $28^{\circ} \mathrm{C}$ e mínima de $14^{\circ} \mathrm{C}$. A 
precipitação média mensal foi de $79 \mathrm{~mm}$, com total de $394 \mathrm{~mm}$ no período (Apêndice 1).

No decorrer dos experimentos foram realizados as adubações e os tratos culturais recomendados para a cultura do milho, incluindo-se irrigação. Os tratamentos foram dispostos em delineamento blocos casualizados, com quatro repetições, num total de 24 parcelas, tanto para as misturas entre as linhagens L1 e L2 (ensaio A) como para L3 e L4 (ensaio B). Cada parcela foi constituída por quatro linhas de 20 metros lineares, espaçadas 80 centímetros entre si, com estande de cinco plantas por metro linear. As duas linhas externas constituíram as bordaduras.

As avaliações foram efetuadas em diferentes estádios de desenvolvimento da planta, observando-se as caraterísticas descritas no Quadro 3, que constituem descritores mínimos do milho, exigidos para registro e proteção de cultivares (Brasil, 1997). A escala fenológica empregada foi a sugerida por Fancelli (1986), adaptada de Nel \& Smith (1978). No experimento conduzido em Cravinhos - SP os dados foram coletados nos estádios 0 (semeadura até duas folhas completamente desenvolvidas) e 1 (planta com quatro folhas desenvolvidas). Para o experimento conduzido em Piracicaba - SP, além do estádio 1, também foram obtidos dados nos estádios 2 (planta com oito folhas desenvolvidas), 3 (planta com doze folhas desenvolvidas), 4 (emissão do pendão), 5 (florescimento e polinização) e 8 (grãos farináceos). Todas as observações foram realizadas por um avaliador, sendo as plantas identificadas como contaminantes marcadas com uma fita plástica de cor diferente, em cada avaliação. Esses resultados foram comparados com características das espigas colhidas, para verificação da precisão das avaliações realizadas durante os estádios de desenvolvimento.

Logo após o florescimento, procedeu-se as determinações do ângulo de inserção entre a lâmina da folha e o caule, considerando o nó correspondente à inserção da espiga superior, com o auxílio de um transferidor, e da altura de 
plantas, avaliada desde a superfície do solo até a inserção da última folha completamente desenvolvida, utilizando-se uma régua graduada. Os resultados foram expressos em graus, para o ângulo de inserção da folha e em centímetros para a variável altura de planta. Essas avaliações tiveram por objetivo determinar se, numericamente, seria possível identificar a presença de contaminantes nas amostras em análise.

\begin{tabular}{|c|c|c|c|c|}
\hline Características da planta & L1 & $\mathrm{L} 2$ & L3 & L4 \\
\hline $\begin{array}{l}\text { Pigmentação pela } \\
\text { antocianina no coleoptilo }\end{array}$ & ausente & $\begin{array}{l}\text { presente } \\
\text { (fraca) }\end{array}$ & ausente & $\begin{array}{l}\text { presente } \\
\text { (fraca) }\end{array}$ \\
\hline $\begin{array}{l}\text { Pigmentação pela } \\
\text { antocianina na nervura } \\
\text { central da folha (estádio } \\
\text { zero) }\end{array}$ & $\begin{array}{l}\text { presente } \\
\text { (fraca) }\end{array}$ & $\begin{array}{l}\text { presente } \\
\text { (fraca) }\end{array}$ & $\begin{array}{l}\text { presente } \\
\text { (fraca) }\end{array}$ & $\begin{array}{l}\text { presente } \\
\text { (intensa) }\end{array}$ \\
\hline $\begin{array}{l}\text { Pigmentação pela } \\
\text { antocianina na nervura } \\
\text { central da folha (estádio 1) }\end{array}$ & ausente & ausente & ausente & ausente \\
\hline $\begin{array}{l}\text { Pigmentação pela } \\
\text { antocianina na bainha foliar } \\
\text { (estádio zero) }\end{array}$ & ausente & $\begin{array}{l}\text { presente } \\
\text { (fraca) }\end{array}$ & ausente & $\begin{array}{l}\text { presente } \\
\text { (intensa) }\end{array}$ \\
\hline $\begin{array}{l}\text { Pigmentação pela } \\
\text { antocianina na bainha foliar } \\
\text { (estádio 1) }\end{array}$ & ausente & ausente & ausente & $\begin{array}{l}\text { presente } \\
\text { (intensa) }\end{array}$ \\
\hline $\begin{array}{l}\text { Pigmentação pela } \\
\text { antocianina na borda da } \\
\text { lâmina foliar (estádio zero) }\end{array}$ & ausente & $\begin{array}{l}\text { presente } \\
\text { (fraca) }\end{array}$ & ausente & $\begin{array}{l}\text { presente } \\
\text { (fraca) }\end{array}$ \\
\hline $\begin{array}{l}\text { Pigmentação pela } \\
\text { antocianina na borda da } \\
\text { lâmina foliar (estádio 1) }\end{array}$ & ausente & ausente & ausente & ausente \\
\hline $\begin{array}{l}\text { Número de internódios no } \\
\text { colmo }\end{array}$ & 14 a16 & 11 a 13 & $14-16$ & $11-13$ \\
\hline
\end{tabular}

Quadro 3 - Características morfológicas utilizadas na diferenciação de linhagens (L1, L2, L3 e L4) de milho, baseadas nos descritores mínimos exigidos para registro de cultivares (Brasil, 1997), com avaliações em vários estádios de desenvolvimento, em experimentos conduzidos em Cravinhos - SP e Piracicaba - SP 


\begin{tabular}{|c|c|c|c|c|}
\hline Características da planta & L1 & $\mathrm{L} 2$ & L3 & L4 \\
\hline $\begin{array}{l}\text { Pigmentação pela } \\
\text { antocianina nas raízes } \\
\text { aéreas }\end{array}$ & ausente & $\begin{array}{l}\text { presente } \\
\text { (intensa) }\end{array}$ & $\begin{array}{l}\text { presente } \\
\text { (fraca) }\end{array}$ & $\begin{array}{l}\text { presente } \\
\text { (fraca) }\end{array}$ \\
\hline $\begin{array}{l}\text { Intensidade da cor verde na } \\
\text { última folha desenvolvida }\end{array}$ & escuro & médio & escuro & claro \\
\hline $\begin{array}{l}\text { Forma da extremidade da } \\
\text { última folha desenvolvida }\end{array}$ & pontiaguda & arredondada & arredondada & $\begin{array}{l}\text { pontiaguda/ } \\
\text { arredondada }\end{array}$ \\
\hline $\begin{array}{l}\text { Posição em relação ao colmo } \\
\text { da última folha desenvolvida }\end{array}$ & ereta & recurvada & recurvada & semi-ereta \\
\hline $\begin{array}{l}\text { Pubescência na bainha da } \\
\text { última folha desenvolvida }\end{array}$ & $\begin{array}{l}\text { presente } \\
\text { (média) }\end{array}$ & $\begin{array}{c}\text { presente } \\
\text { (abundante) }\end{array}$ & $\begin{array}{l}\text { presente } \\
\text { (média) }\end{array}$ & $\begin{array}{l}\text { presente } \\
\text { (fraca) }\end{array}$ \\
\hline $\begin{array}{l}\text { Intensidade da cor verde no } \\
\text { colmo }\end{array}$ & escuro & amarelado & escuro & claro \\
\hline Antocianina nas anteras & $\begin{array}{l}\text { presente } \\
\text { (fraca) }\end{array}$ & $\begin{array}{l}\text { presente } \\
\text { (fraca) }\end{array}$ & $\begin{array}{l}\text { presente } \\
\text { (média) }\end{array}$ & $\begin{array}{l}\text { presente } \\
\text { (intensa) }\end{array}$ \\
\hline $\begin{array}{l}\text { Comprimento da haste } \\
\text { principal do colmo }\end{array}$ & $\begin{array}{l}\text { médio } \\
(29 \mathrm{~cm})\end{array}$ & $\begin{array}{l}\text { longo } \\
(48 \mathrm{~cm})\end{array}$ & $\begin{array}{l}\text { longo } \\
(39 \mathrm{~cm})\end{array}$ & $\begin{array}{l}\text { longo } \\
(35 \mathrm{~cm})\end{array}$ \\
\hline $\begin{array}{l}\text { Posição das ramificações } \\
\text { laterais em relação à haste } \\
\text { do colmo }\end{array}$ & recurvada & $\begin{array}{l}\text { ligeiramente } \\
\text { recurvada }\end{array}$ & $\begin{array}{l}\text { fortemente } \\
\text { recurvada }\end{array}$ & reta \\
\hline $\begin{array}{l}\text { Antocianina nos estilo- } \\
\text { estigmas }\end{array}$ & $\begin{array}{l}\text { presente } \\
\text { (intensa) }\end{array}$ & $\begin{array}{l}\text { presente } \\
\text { (média) }\end{array}$ & $\begin{array}{l}\text { presente } \\
\text { (fraca) }\end{array}$ & $\begin{array}{l}\text { presente } \\
\text { (média) }\end{array}$ \\
\hline $\begin{array}{l}\text { Posição das espigas na } \\
\text { planta }\end{array}$ & ereta & oblíqua & oblíqua & ereta \\
\hline Forma das espigas & $\begin{array}{l}\text { cônica/ } \\
\text { cilíndrica }\end{array}$ & cilíndrica & $\begin{array}{l}\text { cônica/ } \\
\text { cilíndrica }\end{array}$ & cônica \\
\hline $\begin{array}{l}\text { Cor de palha das espigas } \\
\text { (verde) }\end{array}$ & escuro & claro & escuro & claro \\
\hline $\begin{array}{l}\text { Compactação de palha nas } \\
\text { espigas }\end{array}$ & frouxa & compacta & compacta & compacta \\
\hline Ciclo (graus dia) & $(851-900)$ & $(>950)$ & $(901-950)$ & $(>950)$ \\
\hline
\end{tabular}

Quadro 3 - Características morfológicas utilizadas na diferenciação de linhagens (L1, L2, L3 e L4) de milho, baseadas nos descritores mínimos exigidos para registro de cultivares (Brasil, 1997), com avaliações em vários estádios de desenvolvimento, em experimentos conduzidos em Cravinhos - SP e Piracicaba - SP 


\subsubsection{Análise estatística}

Os dados referentes às avaliações preliminares, ao comprimento de plântula, altura de planta e ângulo de inserção da folha foram analisados por meio de análise de variância seguida de teste de Tukey, para a comparação de médias, em nível de $5 \%$ de probabilidade, com o auxílio do programa estatístico SAS ${ }^{\circledR}$, versão 6.12 para Windows (SAS, 1996)

Com relação aos dados de observações referentes a caraterísticas morfológicas de sementes, plântulas e plantas, foram calculadas as percentagens de acerto, erro e o desvio padrão da média dos resultados obtidos nas quatro repetições de cada ensaio, conforme Pimentel Gomes (1987). Nas avaliações realizadas por três avaliadores, calcularam-se as porcentagens a partir do valor médio obtido.

A porcentagem de acerto foi calculada mediante o quociente da freqüência observada pela freqüência esperada, multiplicado por cem. Para a análise do erro foram computadas as observações das linhagens contaminantes não identificadas e das puras classificadas como contaminantes.

Para verificar a significância dos desvios ocorridos entre os resultados

obtidos pelos avaliadores, foi utilizado o teste do qui-quadrado $\left(\gamma^{2}\right)$. Neste teste, os desvios foram transformados em um único valor de $\gamma^{2}$, representando a medida padronizada da magnitude dos desvios (Ramalho et al., 1990).

O valor $\gamma^{2}$ foi estimado pela seguinte expressão:

$\gamma^{2}=\Sigma[(\mathrm{Fo}-\mathrm{Fe})-0,5]^{2} / \mathrm{Fe}$

Sendo:

Fo: freqüência observada de linhagens contaminantes nas amostras.

Fe: freqüência esperada de linhagens contaminantes nas amostras

0,5: fator de correção de Yates 
Os dados de freqüência observada foram representados pela média das quatro repetições para cada avaliador.

Nos dados referentes à porcentagem média de acertos na identificação das linhagens contaminantes, obtidas para cada estádio de desenvolvimento da cultura do milho, em experimento conduzido em Piracicaba - SP, também foi realizada a análise de variância seguida de teste de Tukey. Os dados em porcentagem foram transformados para arc sen $\sqrt{ }(x+0,5 / 100)$.

\subsection{Marcadores microssatélites}

\subsubsection{Tecido vegetal}

Para a avaliação da pureza varietal dos lotes de sementes de linhagem de milho utilizando marcadores microssatélites extraiu-se DNA de sementes e de folhas de plântulas. Na análise de sementes foram utilizadas 100 unidades trituradas em moinho comum (peneira Granutest 270) por dois minutos, resfriadas em nitrogênio líquido $\left(-196^{\circ} \mathrm{C}\right)$ e armazenadas em "ultrafreezer" ($80^{\circ} \mathrm{C}$ ) para isolamento de DNA. Para a análise das folhas foram utilizados 100 pares de folhas coletadas aos quatro dias após a emergência das plântulas, extraídas com auxílio de bisturi cirúrgico, maceradas em cadinho, na presença de nitrogênio líquido, e armazenadas em tubos de propileno de $50 \mathrm{~mL}$ em "ultrafreezer" $\left(-80^{\circ} \mathrm{C}\right)$ até a extração de DNA. As plântulas foram cultivadas sob condições de temperatura ambiente, em caixas plásticas contendo areia, umedecida a $60 \%$ de sua capacidade de retenção de água. 


\subsubsection{Extração de DNA vegetal}

A extração de DNA das amostras foi realizada de acordo com protocolo modificado de Hoisington et al. (1994). Foram utilizadas, aproximadamente, cinco gramas de amostra de folhas e três gramas de amostra de sementes colocadas em tubos plásticos de fundo cônico de $50 \mathrm{~mL}$ e ressuspendidas em $10 \mathrm{~mL}$ de tampão de extração CTAB 1\% (70 $\mu \mathrm{M}$ de NaCl; $50 \mu \mathrm{M}$ de EDTA pH 8,0; $100 \mu \mathrm{M}$ Tris- $\mathrm{HCl} \mathrm{pH}$ 7,5; $1 \%$ de $\mathrm{p} / \mathrm{v}$ de CTAB; $1 \%$ de $\mathrm{p} / \mathrm{v}$ de polivinil pyrrolidone, $140 \mu \mathrm{M}$ de $\beta$-mercaptoetanol e água destilada deionizada). A seguir, as amostras foram incubadas em banho-maria a $65^{\circ} \mathrm{C}$ por aproximadamente 60 minutos, sendo agitadas levemente a cada cinco minutos. Em seguida, foram adicionadas de $4,5 \mathrm{~mL}$ de clorofórmio/álcool isoamílico (CIA) na proporção de 24:1 (v:v), efetuando-se inversão dos tubos seguida de centrifugação à $3400 \mathrm{rpm}$ por 10 minutos. O sobrenadante foi transferido para novos tubos e o procedimento foi repetido mais uma vez. Ao sobrenadante foi adicionado igual volume de isopropanol absoluto resfriado a $-20^{\circ} \mathrm{C}$, promovendo a precipitação do DNA, o qual foi centrifugado e seco ao ar. Os precipitados foram lavados com etanol $75 \%$ por dois minutos e etanol absoluto por mais dois minutos. Após secagem em temperatura ambiente, o DNA foi ressuspendido em $100 \mu \mathrm{L}$ de TE pH 8,0 (10 mM de Tris- $\mathrm{HCl}$ e $1 \mathrm{mM}$ de EDTA).

Em todas as extrações, um tratamento com a enzima RNAse se fez necessário. Aos $100 \mu \mathrm{L}$ de DNA em suspensão foi adicionado $1 \mu \mathrm{L}$ de RNAse $\left(1 \mathrm{mg} \cdot \mathrm{mL}^{-1}\right)$, incubando a $37^{\circ} \mathrm{C}$ por duas horas. Em seguida, a suspensão de DNA foi armazenada a $4^{\circ} \mathrm{C}$ até o momento do uso.

A concentração do DNA foi estimada através de fluorímetro (Hoefer Dyna Quant 200). A integridade do DNA foi avaliada por eletroforese em gel de agarose 0,8 \% em tampão TBE 1x (5,4 g de Tris-base; 2,75 g de ácido bórico; 2,0 mL de EDTA pH 8,0 e água destilada e deionizada até completar o volume de $100 \mathrm{~mL}$ ). Para a visualização do DNA, o gel recebeu, após a fusão 
da agarose, brometo de etídio na proporção de $0,5 \mu \mathrm{g} \cdot \mathrm{mL}^{-1}$ de gel. Após a eletroforese, o gel foi fotografado com aparelho ImageMaster®VDS (Pharmacia Biotech) sob luz ultra-violeta.

\subsubsection{Amplificação de locos microssatélites}

A otimização das reações de amplificação foi realizada com amostras contendo L1 e L2. Fez-se necessário aumentar a concentração de DNA molde, assim como o volume final da reação proposta por Senior et al. (1996). De 30ng passou a se utilizar 80ng, enquanto o volume de reação foi duplicado, ou seja, de $20 \mu \mathrm{L}$ iniciais, foram utilizados $40 \mu \mathrm{L}$. Portanto, em cada reação foram adicionados em um tubo $80 \mathrm{ng}$ de DNA molde, 1,0 unidade de Taq DNA polimerase, 1x tampão da Taq, 2,25 mM MgCl $2,60 \mu \mathrm{M}$ de cada $\operatorname{dNTP}(A, C, G, T), 0,5 \mu \mathrm{M}$ de iniciadores anverso e reverso e 19,7 $\mu \mathrm{L}$ de água ultrapura autoclavada, sendo o volume final de $40 \mu \mathrm{L}$. Para evitar a evaporação da reação durante a amplificação, cada amostra recebeu uma gota de óleo mineral. Para determinar quais iniciadores seriam mais apropriados, foram avaliados 27 (Tabela 2), previamente selecionados do banco de "primers" disponíveis para milho (Research Genetics - EUA), em função do padrão polimórfico de bandas apresentado em outros estudos desenvolvidos no Laboratório de Genética Molecular do Departamento de Entomologia, Fitopatologia e Zoologia Agrícola da ESALQ. Dentre esses, foram escolhidos os que apresentaram padrões polimórficos de amplificação de fragmentos entre as linhagens estudadas. Para as amostras contendo misturas entre as linhagens L1 e L2 utilizou-se o iniciador BNLG 125 e para L3 e L4 selecionou-se o iniciador BNLG 240.

Utilizou-se o programa de amplificação otimizado por Ogliari et al. (2000), com um ciclo inicial de três minutos a $94^{\circ} \mathrm{C}$, seguido de 10 ciclos a $94^{\circ} \mathrm{C}$ por um minuto, $65^{\circ} \mathrm{C}$ por um minuto e $72^{\circ} \mathrm{C}$ por dois minutos, sendo que 
a cada dois ciclos a temperatura de anelamento foi reduzida em $1^{\circ} \mathrm{C}$ até atingir $55^{\circ} \mathrm{C}$. Outros 19 ciclos a $94^{\circ} \mathrm{C}$ por um minuto, $55^{\circ} \mathrm{C}$ por um minuto e $72^{\circ} \mathrm{C}$ por dois minutos, também fazem parte do programa que se encerra com uma etapa de cinco minutos a $72^{\circ} \mathrm{C}$. O equipamento utilizado nas amplificações foi um termociclador PTC-100 (M.J. Research, INC).

Tabela 2. Iniciadores anverso (A) e reverso (R) de locos microssatélites (Research Genetics - EUA) testados, sua localização no mapa genômico e respectivas sequências

\begin{tabular}{|c|c|c|}
\hline LOCO SSR & $\mathrm{BIN}^{1}$ & SEQUÊNCIA \\
\hline Bnlg 149 & 1.00 & $\begin{array}{l}\text { A: CATCCTCCAAAAGCACTACGT // } \\
\text { R: CAGCTGTCCGACACTTATTCTGTA }\end{array}$ \\
\hline Bnlg 1007 & 1.02 & $\begin{array}{l}\text { A: GATGCAATAAAGGTTGCCGT // } \\
\text { R: ATGTGCTGTGCCTGCCTC }\end{array}$ \\
\hline Bnlg 125 & 2.03 & $\begin{array}{l}\text { A: GGGACAAAAGAAGAAGCAGAG // } \\
\text { R: GAAATGGGACAGAGACAGACAAT }\end{array}$ \\
\hline Bnlg 1017 & 2.02 & $\begin{array}{l}\text { A: ATTGGAAGGATCTGCGTGAC // } \\
\text { R: CAGCTGGTGGACTGCATCTA }\end{array}$ \\
\hline Bnlg 381 & 2.04 & $\begin{array}{l}\text { A: TCCCTCTTGAGTGTTTATCACAAA // } \\
\text { R: GTTTCCATGGGCAGGTGTAT }\end{array}$ \\
\hline Dupssr 21 & 2.05 & $\begin{array}{l}\text { A: GTGCAAACTAATCCAAAGCAA // } \\
\text { R: ATGTAGGGACAAAGGAATAAATCA }\end{array}$ \\
\hline Bnlg 1045 & 2.07 & $\begin{array}{l}\text { A: TCCCCGATAGCATATCGATC // } \\
\text { R: GTGACTTTGGGGAGTTTGGA }\end{array}$ \\
\hline Phi 073 & 3.05 & $\begin{array}{l}\text { A: GTGCGAGAGGCTTGACCAA // } \\
\text { R: AAGGGTTGAGGGCGAGGAA }\end{array}$ \\
\hline Bnlg 197 & 3.06 & $\begin{array}{l}\text { A: GCGAGAAGAAAGCGAGCAGA // } \\
\text { R: CGCCAAGAAGAAACACATCACA }\end{array}$ \\
\hline Bnlg 490 & 4.04 & $\begin{array}{l}\text { A: GCCCTAGCTTGCTAATTAACTAACA // } \\
\text { R: ACTGTAAGGGCAGTGGACCTATA }\end{array}$ \\
\hline Bnlg 2291 & 4.06 & $\begin{array}{l}\text { A: CCTCTCGATGTTCTGAAGCC // } \\
\text { R: GTCATAACCTTGCCTCCCAA }\end{array}$ \\
\hline Bnlg 292a & 4.08 & $\begin{array}{l}\text { A: TGGTAGGACCTTACAATGGGA // } \\
\text { R: CGGGAGTACTGCTACACACGA }\end{array}$ \\
\hline Bnlg 589 & 4.10 & $\begin{array}{l}\text { A: GGGTCGTTTAGGGAGGCACCTTTGGT // } \\
\text { R: CGACAGACAGACAGACAAGCGCATTGT }\end{array}$ \\
\hline Bnlg 339 & 7.03 & $\begin{array}{l}\text { A: CCAACCGTATCAGCATCAGC // } \\
\text { R: GCAGAGCTCTCATCGTCTTCTT }\end{array}$ \\
\hline Phi 115 & 8.03 & $\begin{array}{l}\text { A: GCTCCGTGTTTCGCCTGAA // } \\
\text { R: ACCATCACCTGAATCCATCACA }\end{array}$ \\
\hline
\end{tabular}


Tabela 2. Iniciadores anverso $(A)$ e reverso $(R)$ de locos microssatélites (Research Genetics - EUA) testados, sua localização no mapa genômico e respectivas sequências

\begin{tabular}{|c|c|c|}
\hline LOCO SSR & $\mathrm{BIN}^{1}$ & SEQUÊNCIA \\
\hline Bnlg 240 & 8.03 & $\begin{array}{l}\text { A: AAGAACAGAAGGCATTGATACATAA // } \\
\text { R: TGCAGGTGTATGGGCAGCTA }\end{array}$ \\
\hline Bnlg 557 & 5.03 & $\begin{array}{l}\text { A: TCACGGGCGTAGAGAGAGA // } \\
\text { R: CGAAGAAACAGCAGGAGATGAC }\end{array}$ \\
\hline Bnlg 238 & 6.00 & $\begin{array}{l}\text { A: TCCTGCTTATTGCTTTCGTCAT // } \\
\text { R: GAGCTTGCATATTTCTTGTGGACA }\end{array}$ \\
\hline Bnlg 1292 & 7.01 & $\begin{array}{l}\text { A: GGCGCGCACATAGCTC // } \\
\text { R. GCCTGGGCTGGCTTCA }\end{array}$ \\
\hline Phi 034 & 7.02 & $\begin{array}{l}\text { A: TAGCGACAGGATGGCCTCTTCT // } \\
\text { R: GGGGAGCACGCCTTCGTTCT }\end{array}$ \\
\hline Phi 033 & 9.01 & $\begin{array}{l}\text { A: ATCGAAATGCAGGCGATGGTTCTC // } \\
\text { R: ATCGAGATGTTCTACGCCCTGAAGT }\end{array}$ \\
\hline Umc 1033 & 9.03 & $\begin{array}{l}\text { A: CTTCTTCGTAAAGGCATTTTGTGGC // } \\
\text { R: GTGCGGGATTCCTTAGTTTGC }\end{array}$ \\
\hline Phi 022 & 9.03 & $\begin{array}{l}\text { A: TGCGCACCAGCGACTGACC // } \\
\text { R: GCGGGCGACGCTTCCAAAC }\end{array}$ \\
\hline Phi 061 & 9.03 & $\begin{array}{l}\text { A: GACGTAAGCCTAGCTCTGCCAT // } \\
\text { R: AAACAAGAACGGCGGTGCTGATTC }\end{array}$ \\
\hline Phi 065 & 9.03 & $\begin{array}{l}\text { A: AGGGACAAATACGTGGAGACACAG // } \\
\text { R: CGATCTGCACAAAGTGGAGTAGTC }\end{array}$ \\
\hline Bnlg 127 & 9.03 & $\begin{array}{l}\text { A: CATGTATACGAGAAGCACCCTAT // } \\
\text { R: ATCGTAACTCAGCGGTTTGTG }\end{array}$ \\
\hline Bnlg 236 & 10.06 & $\begin{array}{l}\text { A: CGCTTTGCAGTACCAGTACACAC /" } \\
\text { R: GACGACAACTGCAGAGTACCAGA }\end{array}$ \\
\hline
\end{tabular}

\subsubsection{Resolução dos fragmentos amplificados}

Após a amplificação, os fragmentos foram resolvidos por eletroforese em gel de agarose $3,5 \%$ e em gel de poliacrilamida [acrilamida/bisacrilamida (19:1) 6\%, uréia 7,5M, tampão TBE 1x]. Para a resolução por eletroforese em gel de agarose, amostras de $10 \mu \mathrm{L}$ do produto amplificado receberam $4 \mu \mathrm{L}$ de

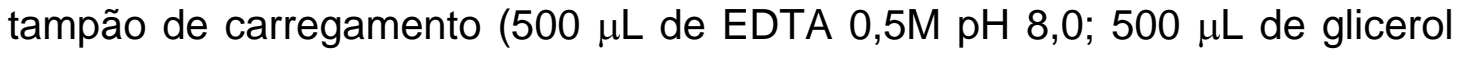
$99 \%$ e $2,16 \mathrm{mg}$ de bromofenol), sendo submetida a eletroforese em tampão 
TBE 1x, por aproximadamente duas horas e trinta minutos a 60 volts. Cada gel recebeu em uma das extremidades um padrão molecular do tipo "ladder" $50 \mathrm{pb}$ (Promega) para a informação do peso molecular dos fragmentos resolvidos. O gel foi tratado com brometo de etídio na proporção de 0,5 $\mu \mathrm{g} \cdot \mathrm{mL}^{-1}$ de gel. Após a eletroforese, o gel foi fotografado com aparelho ImageMaster $®$ VDS (Pharmacia Biotech) sob luz ultra-violeta.

Para a resolução dos fragmentos amplificados em gel de poliacrilamida de 0,5 mm de espessura, foi utilizado o sistema eletroforético "Sequi-Gen GT" (Biorad) de $38 \times 50 \mathrm{~cm}$ e pente para 50 amostras. No preparo de um litro da solução matriz dos géis, foram utilizados 420,2 g de uréia, $200 \mathrm{~mL}$ de TBE 5x, $150 \mathrm{~mL}$ de acrilamida/bisacrilamida 40\% (19:1), sendo o volume final ajustado para um litro com água ultrapura. A solução matriz foi filtrada em filtro $0,2 \mu \mathrm{m}$ e armazenada em frascos âmbar envoltos em papel alumínio e mantida em refrigerador.

As placas utilizadas para abrigar o gel foram cuidadosamente limpas, utilizando-se etanol 95\%, em duas lavagens. Em uma das placas foram aplicados $1500 \mu \mathrm{L}$ de REPEL (Amersham) utilizando-se lenços de papel através de movimentos circulares. Cinco minutos após a secagem do produto, procedeu-se a retirada do excesso, utilizando novamente lenços de papel e etanol 95\%. Para o tratamento da outra placa, onde o gel se adere, utilizou-se a mistura de $1000 \mu \mathrm{L}$ de etanol 95\%, $5 \mu \mathrm{L}$ de ácido acético glacial e $5 \mu \mathrm{L}$ de BIND (Amersham). Após o preparo, o produto foi aplicado sobre a placa utilizando lenços de papel com movimentos circulares. A retirada do excesso foi realizada de forma idêntica a da placa anterior.

Para o preparo do gel utilizaram-se $120 \mathrm{~mL}$ da solução matriz, $120 \mu \mathrm{L}$ de TEMED ( $N, N, N$ ', N'- Tetramethylethilethilenediamine) e $800 \mu \mathrm{L}$ de persulfato de amônio 10\%. O tempo médio de polimerização foi de 50 minutos. Após a polimerização, o gel foi submetido a uma eletroforese inicial ("pré-corrida") sob potência constante de 80W por uma hora, sendo a parte 
superior da cuba preenchida com TBE 1x e a parte inferior com TBE 1x acrescido de acetato de sódio 0,375 M. Antes de aplicar os produtos amplificados, adicionou-se $9 \mu \mathrm{L}$ de tampão formamida (formamida $98 \%$, EDTA 10mM pH 8,0, azul de bromofenol 0,002 \% p/v e xileno cianol 0,002 \% $\mathrm{p} / \mathrm{v})$, procedendo-se a desnaturação a $95^{\circ} \mathrm{C}$ por cinco minutos. Em seguida, $16 \mu \mathrm{L}$ de cada amostra foram aplicados no gel e a eletroforese foi conduzida sob potência constante de $80 \mathrm{~W}$ durante duas horas e trinta minutos.

Para a revelação dos fragmentos utilizou-se o método de coloração com nitrato de prata, seguindo o protocolo proposto por Creste et al. (2001) com modificações. A placa menor contendo o gel aderido foi imersa em dois litros de solução de fixação (etanol $10 \%$ e ácido acético $1 \%$ ) e mantida sob agitação lenta por 10 minutos. Após a fixação, o gel foi lavado em dois litros de água deionizada, durante um minuto, sendo em seguida submetido a um pré-tratamento pela imersão em solução de oxidação (ácido nítrico 1,5\%) durante dois minutos e quarenta segundos, sempre sob agitação lenta. Para retirada do excesso de solução procedeu-se nova lavagem em água. Posteriormente, o gel foi imerso em dois litros de solução de $\mathrm{AgNO}_{3}$ durante 20 minutos, sob agitação. Para a retirada dessa solução foram realizadas duas lavagens em água, por 30 segundos cada. A seguir, o gel foi transferido para um litro de solução de revelação $\left(\mathrm{Na}_{2} \mathrm{CO}_{3} 3 \%\right.$ e formaldeído $\left.0,02 \%\right)$ sob agitação lenta e constante. Quando visualizaram-se as primeiras bandas, o gel foi transferido para nova solução de revelação de igual volume e agitado constantemente. Após obter o padrão de revelação desejado, o gel foi imerso em dois litros de solução bloqueadora (ácido acético glacial 5\%) e mantido por cinco minutos sob lenta agitação para, finalmente, passar pela última lavagem em dois litros de água deionizada por um minuto sob agitação lenta.

Os géis foram mantidos a temperatura ambiente para secagem, sendo posteriormente analisados em transiluminador de luz branca e documentado via fotodocumentação. 
A detecção da mistura varietal, em cada tratamento, foi possível pela observação da presença de banda da linhagem contaminante associada à presença de banda característica da linhagem pura, ou seja, quando a amostra se encontrava contaminada, duas bandas eram observadas. Estes resultados foram observados tanto em gel de matriz de agarose como de poliacrilamida.

\subsubsection{Sensibilidade dos marcadores microssatélites para avaliar pureza varietal através da simulação de contaminação em amostras de DNA}

Neste estudo foram simuladas contaminações de 0\%, 0,01\%, 0,013\%, $0,02 \%, 0,04 \%, 0,1 \%, 0,2 \%, 1 \%, 2 \%, 5 \%, 10 \%$ e $100 \%$ da linhagem denominada contaminante em amostras da linhagem pura, correspondendo as proporções entre sementes puras e contaminantes de 100:0, 9.999:1, 7.499:1, 4.999:1, 2499:1, 999:1, 499:1, 99:1, 98:2, 95:5, 90:10, 0:100. Para tanto, alíquotas de DNA obtido da linhagem L2 foram adicionadas às alíquotas de DNA da linhagem L1 (ensaio A) e alíquotas de DNA da linhagem L4 foram adicionadas às soluções com DNA da linhagem L3 (ensaio B), simulando contaminações de concentrações variadas e conhecidas para cada mistura (Tabela 3). O intuito deste teste foi verificar a sensibilidade do método baseado em marcadores microssatélites em detectar os menores níveis possíveis de contaminação.

As reações de amplificação foram feitas de forma idêntica ao item 3.3.3 e os procedimentos de amplificação realizados de acordo com Ogliari et al. (2000). A resolução dos fragmentos amplificados ocorreu em gel de poliacrilamida seguindo o item 3.3.4., com revelação do gel realizada pelo método de coloração com nitrato de prata, seguindo o protocolo proposto por Creste et al. (2001). A detecção dos níveis de contaminação estabelecidos 
compreendeu a observação da presença de uma banda característica da linhagem contaminante juntamente com uma banda característica da linhsgem pura.

Tabela 3. Descrição de tratamentos contendo diferentes níveis de misturas de DNA de sementes e folhas de plântulas de linhagens de milho, onde L2 foi misturada à amostras de L1, em um ensaio A e L4 foi misturada à amostras de L3, em um ensaio $B$

\begin{tabular}{|c|c|c|c|}
\hline \multicolumn{2}{|r|}{ Ensaio A } & \multicolumn{2}{|r|}{ Ensaio B } \\
\hline Tratamento & Descrição & Tratamento & Descrição \\
\hline T1 & $100 \%$ L1 + 0\% L2 & T13 & $100 \%$ L3 + 0\% L4 \\
\hline T2 & $99,99 \%$ L1 + 0,01\% L2 & T14 & $99,99 \%$ L3 + 0,01\% L4 \\
\hline T3 & $99,987 \%$ L1 + 0,013\% L2 & T15 & $99,987 \% \mathrm{~L} 3+0,013 \%$ L4 \\
\hline T4 & $99,98 \%$ L1 + 0,02\% L2 & T16 & $99,98 \%$ L3 + 0,02\% L4 \\
\hline T5 & $99,96 \%$ L1 + 0,04\% L2 & T17 & $99,96 \%$ L3 + 0,04\% L4 \\
\hline T6 & $99,9 \%$ L1 + 0,1\% L2 & T18 & $99,9 \%$ L3 + 0,1\% L4 \\
\hline $\mathrm{T} 7$ & $99,8 \%$ L1 + 0,2\% L2 & T19 & $99,8 \%$ L3 + 0,2\% L4 \\
\hline T8 & 99\% L1 + 1\% L2 & T20 & $99 \%$ L3 + 1\% L4 \\
\hline T9 & $98 \%$ L1 + 2\% L2 & T21 & $98 \%$ L3 + 2\% L4 \\
\hline T10 & $95 \%$ L1 + 5\% L2 & T22 & $95 \%$ L3 + 5\% L4 \\
\hline T11 & $90 \%$ L1 + 10\% L2 & T23 & $90 \%$ L3 + 10\% L4 \\
\hline T12 & $0 \%$ L1 + 100\% L2 & T24 & $0 \%$ L3 + 100\% L4 \\
\hline
\end{tabular}




\section{RESULTADOS E DISCUSSÃO}

\subsection{Caracterização preliminar}

Os dados referentes ao potencial fisiológico das sementes de milho das quatro linhagens utilizadas na pesquisa, encontram-se na Tabela 4. Observou-se diferença significativa para a germinação e vigor dos lotes. Houve desempenho inferior da linhagem L2 em relação às demais no que se refere ao vigor e superioridade da germinação das linhagens $L 3$ e $L 4$, em relação a L1 e L2. Quando comparadas duas a duas, ou seja, L1 com L2 e L3 com L4, verificou-se que L2 apresentou desempenho inferior quanto ao vigor, mas não diferiu de L1 no teste de germinação. Enquanto L3 e L4 diferenciaram-se, significativamente, apenas no teste de envelhecimento acelerado. Os resultados de germinação preencheram os padrões para comercialização de sementes básicas de milho sugeridos pela Coordenadoria de Assistência Técnica Integrada (CATI, 1999).

Com relação aos resultados dos testes de vigor, esses fornecem informações úteis a respeito do desempenho potencial das sementes em campo e durante o armazenamento (Hampton \& Tekrony, 1995), permitindo detectar causas de um possível desenvolvimento desigual de plântulas, em decorrência de diferenças entre genótipos ou potencial fisiológico. Parâmetros como a velocidade de emergência e a sensibilidade à condições de estresse são afetados pelo vigor; portanto, sementes com menor vigor 
poderiam apresentar menor velocidade de emergência de plântulas, sujeitando-as a maior período de estresse no solo, e desenvolvimento mais lento das plantas na fase vegetativa, que resultam em atraso no florescimento. Porém, esse menor vigor não limita a habilidade de uma planta em expressar seu potencial genético (Dornbos Jr, 1994). Assim, a interferência do vigor pode ocorrer nos estádios iniciais de desenvolvimento da planta, prejudicando as análises nessa fase, sem alterar avaliações em estádios mais avançados, como o reprodutivo.

$\mathrm{Na}$ pesquisa, não foi verificada a interferência do vigor sobre a identificação de contaminantes nas amostras constituídas pelas misturas de L1 e L2 (ensaio A) e de L3 e L4 (ensaio B). A germinação afetou as avaliações realizadas em condições de campo pois, muitas vezes, a não identificação do contaminante ocorreu devido à não germinação da semente desse cultivar, impedindo a sua observação. Isso prejudica a análise, uma vez que em outras condições essa semente pode vir a germinar, servindo como fonte de contaminação para o campo de sementes. Dessa forma, a possibilidade de identificação de contaminação através de testes que utilizem características físicas das sementes ou de outros métodos como os moleculares, que não necessitam da germinação da semente e emergência da plântula, deve ser considerada como mais eficaz.

A sanidade é outro atributo que pode interferir no desempenho das sementes em campo e durante o armazenamento. A presença de patógenos associados às sementes, principalmente em elevada incidência, pode acarretar alterações tanto fisiológicas como morfológicas (Machado, 2000). A descoloração e o apodrecimento da semente são conseqüências da infecção e posterior deterioração causada por patógenos, que impedem a observação nítida das características morfológicas utilizadas na distinção de cultivares.

$\mathrm{Na}$ Tabela 5 podem ser observados os resultados do teste de sanidade, realizado nas sementes de L1, L2, L3 e L4. Foi detectada baixa incidência de Fusarium moniliforme e Aspergillus spp. em todas as amostras avaliadas. A 
ocorrência de Penicillium spp. não foi observada em nenhum dos lotes, enquanto o Cephalosporium sp. foi verificado nas sementes de L3, com incidência inferior a 11\%. Portanto, a sanidade dos lotes foi considerada satisfatória, sugerindo que neste caso, os patógenos não constituíram possível fonte de erros nas análises da pureza varietal.

Tabela 4. Determinações em porcentagem do teor de água inicial (TA), da germinação (TG), primeira contagem da germinação, teste de frio (TF), teste de envelhecimento acelerado (EA), teor de água após o EA [TA(EA)], realizadas para a avaliação do potencial fisiológico de sementes de quatro linhagens de milho

\begin{tabular}{lcccccc}
\hline Linhagens & TA & TG & $1^{\mathrm{a}}$ cont. & TF & EA & TA (EA) \\
L1 & 13,1 & $95 \mathrm{~b}^{1}$ & $82 \mathrm{~b}$ & $98 \mathrm{a}$ & $88 \mathrm{~b}$ & 25,0 \\
L2 & 12,1 & $93 \mathrm{~b}$ & $80 \mathrm{~b}$ & $58 \mathrm{~b}$ & $42 \mathrm{c}$ & 32,1 \\
L3 & 13,1 & $98 \mathrm{a}$ & $90 \mathrm{a}$ & $95 \mathrm{a}$ & $87 \mathrm{~b}$ & 25,4 \\
L4 & 13,0 & $99 \mathrm{a}$ & $88 \mathrm{a}$ & $98 \mathrm{a}$ & $95 \mathrm{a}$ & 27,3 \\
CV (\%) & - & 1,8 & 4,9 & 5,4 & 4,5 & - \\
\hline
\end{tabular}

${ }^{1}$ Médias seguidas de mesma dentro de cada coluna não diferem entre si pelo teste de Tukey; $p \leq 0,05$.

Tabela 5. Avaliação da porcentagem de incidência de Fusarium moniliforme, Cephalosporium sp., Aspergillus sp., Penicillium sp. em sementes de quatro linhagens de milho

\begin{tabular}{|c|c|c|c|c|}
\hline Linhagens & F. moniliforme & Cephalosporium sp. & Penicillium spp. & Aspergillus spp. \\
\hline L1 & $2,0 \mathrm{a}^{1}$ & $0,0 b$ & 0,0 & $1,0 a b$ \\
\hline L2 & $3,0 a$ & $0,0 \mathrm{~b}$ & 0,0 & $2,0 a$ \\
\hline L3 & $3,0 a$ & $11,5 a$ & 0,0 & $0,0 \mathrm{~b}$ \\
\hline L4 & $0,5 a$ & $0,0 b$ & 0,0 & $1,0 a b$ \\
\hline CV (\%) & 57,1 & 26,4 & - & 31,3 \\
\hline
\end{tabular}

\footnotetext{
${ }^{1}$ Médias seguidas de mesma dentro de cada coluna não diferem entre si pelo teste de Tukey; $p \leq 0,05$.
} 


\subsection{Marcadores morfológicos}

\subsubsection{Avaliação de sementes}

A distinção das linhagens L1 e L2 e de L3 e L4, através da observação de características morfológicas das sementes (Quadro 1) permitiu determinar a pureza varietal de lotes de sementes, com variação na eficiência de identificação dos contaminantes (Tabela 6). Verificou-se que a coloração e textura do endosperma foram as características que melhor permitiram a distinção entre L1 e L2, enquanto para L3 e L4, todos os descritores selecionados foram satisfatórios. O endosperma com textura cerosa é um descritor marcante das sementes de L2, assim como o pericarpo bronze e endosperma avermelhado de L4. A coroa amarela das sementes de L3 também facilitou sua distinção das sementes de L4. A presença de algum descritor marcante e específico de um genótipo reduz as dúvidas do analista e aumenta a possibilidade de acertos na identificação de contaminantes nas amostras.

Nas Figuras 1 e 2, podem ser observadas as espigas e sementes de cada uma das linhagens, permitindo visualizar as diferenças na coloração característica de cada genótipo. Nas espigas, foi possível diferenciar os materiais em função da coloração da coroa da semente. Porém, deve ser ressaltado que, nessa pesquisa, optou-se por utilizar genótipos morfologicamente distintos, com a finalidade de garantir a correta simulação de contaminação das amostras a serem utilizadas nos testes moleculares, além de verificar se, mesmo com materiais distintos, a identificação através de marcadores morfológicos seria totalmente segura. 


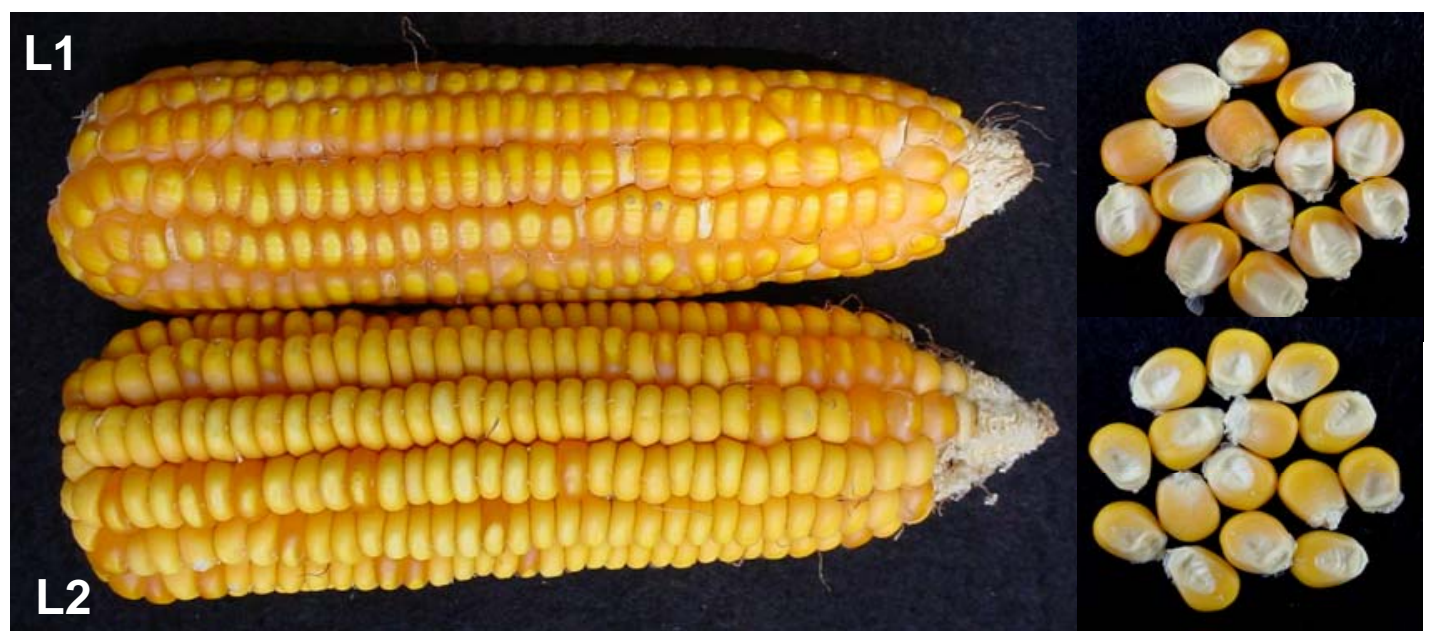

Figura 1- Espigas das linhagens L1, na parte superior da foto, e de L2, na parte inferior, consideradas respectivamente, como puras e contaminantes. No detalhe, sementes debulhadas

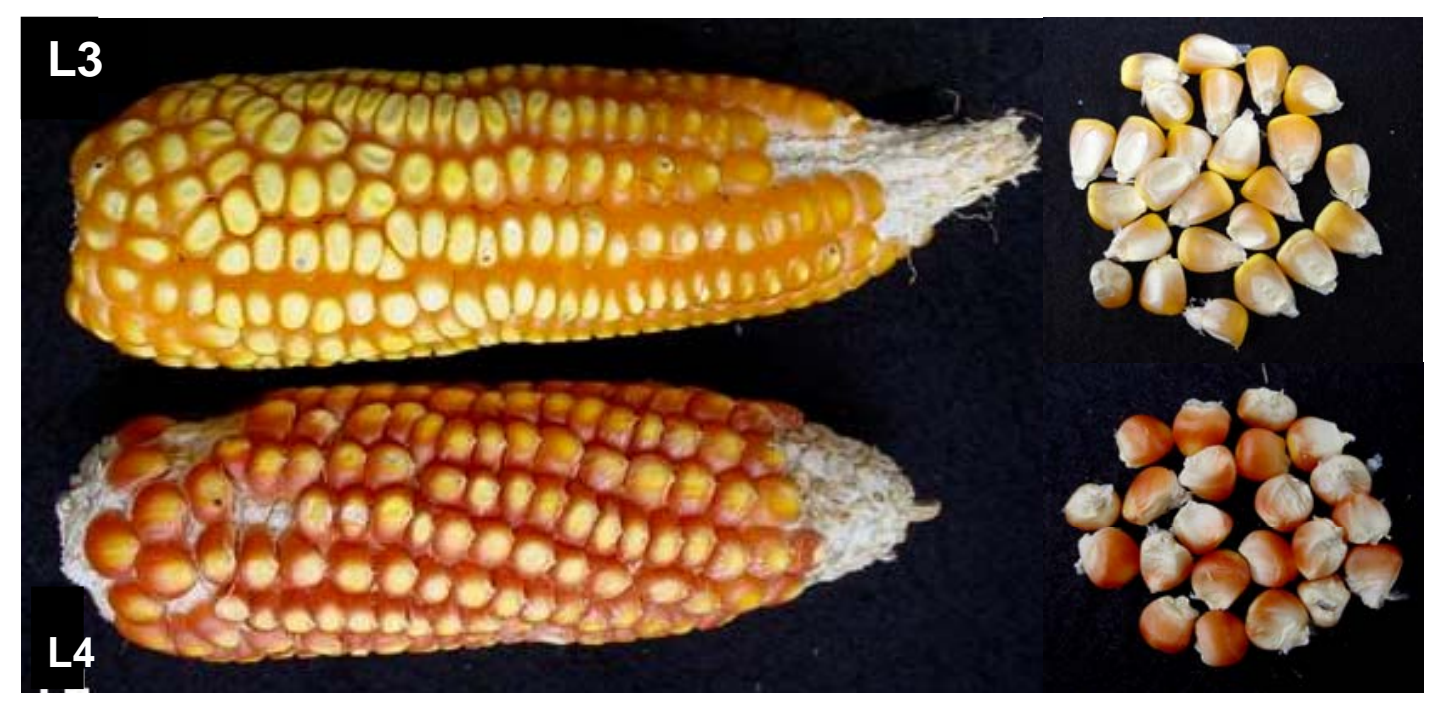

Figura 2. - Espigas das linhagens $L 3$, na parte superior da foto, e de $L 4$, na parte inferior, consideradas respectivamente, como puras e contaminantes. No detalhe, sementes debulhadas 
A visualização de características físicas das sementes em testes de pureza genética e varietal possui vantagens, como a utilização de poucos equipamentos, rapidez e baixo custo (Payne, 1986). Entretanto, apresenta os inconvenientes de exigir treinamento constante de técnicos para assegurar a identificação de novos cultivares, além da menor eficiência e consistência nos resultados, em casos de genótipos com alta semelhança morfológica. Também, a subjetividade na avaliação é um fator prejudicial, pois depende da precisão do observador.

Os resultados apresentados na Tabela 6 permitem observar variação na porcentagem de acertos para a identificação de sementes contaminantes nos diferentes níveis de misturas estudados. As amostras com 100\% de sementes da linhagem L1 (T1) e com 1\% de sementes de L2 misturadas à L1 (T2) foram identificadas com $100 \%$ de acerto por todos os avaliadores, enquanto nos demais tratamentos com a mistura de L1 e L2, inclusive na amostra com $100 \%$ de sementes contaminantes (T6), houve erros de identificação. Neste último tratamento, sementes de L1 foram identificadas como sendo de L2, demostrando que a análise visual de características morfológicas de sementes pode apresentar subjetividade e conduzir a erros; dificultando, inclusive, a quantificação precisa dos níveis de contaminação.

Para o ensaio com L3 e L4, os tratamentos contendo 100\% tanto de sementes consideradas puras (T7) como de contaminantes (T12) foram identificadas com total acerto. A mistura com $2 \%$ de contaminação (T9) também conduziu a esse resultado. Por outro lado, esse mesmo tratamento (T5) foi o identificado com menor precisão (83,3\%) no ensaio $A$, demonstrando não haver um padrão de avaliação para genótipos diversos com o uso de características morfológicas de sementes, ou seja, a identificação de misturas varietais pode variar em função do cultivar. 
Tabela 6. Resultados percentuais de acerto e erro na avaliação da pureza varietal de linhagens de milho (com diferentes proporções de contaminação) através de características morfológicas de sementes

\begin{tabular}{|c|c|c|c|c|c|}
\hline $\begin{array}{l}\text { Ensaio A } \\
\text { Tratamentos } \\
\text { L1 - L2 }\end{array}$ & Acerto & Erro & $\begin{array}{l}\text { Ensaio B } \\
\text { Tratamentos } \\
\text { L3 - L4 }\end{array}$ & Acerto & Erro \\
\hline $\mathrm{T} 1$ & $100,0 \pm 0,0$ & $0,0 \pm 0,0$ & T7 & $100,0 \pm 0,0$ & $0,0 \pm 0,0$ \\
\hline T2 & $100,0 \pm 0,0$ & $0,0 \pm 0,0$ & T8 & $91,7 \pm 14,4$ & $8,3 \pm 14,4$ \\
\hline T3 & $83,3 \pm 19,1$ & $16,8 \pm 19,2$ & T9 & $100,0 \pm 0,0$ & $0,0 \pm 0,0$ \\
\hline T4 & $93,3 \pm 2,9$ & $7,0 \pm 3,0$ & T10 & $91,7 \pm 10,4$ & $8,8 \pm 11,0$ \\
\hline T5 & $95,8 \pm 3,8$ & $4,6 \pm 4,2$ & T11 & $99,2 \pm 1,4$ & $0,9 \pm 1,6$ \\
\hline T6 & $99,5 \pm 0,4$ & $0,5 \pm 0,4$ & T12 & $100,0 \pm 0,0$ & $0,0 \pm 0,0$ \\
\hline
\end{tabular}

As características morfológicas são ferramentas importantes na diferenciação de cultivares; porém, mesmo diante de genótipos visivelmente distintos como L3 e L4, ocorreram erros de identificação que reduziram a eficiência na determinação da pureza varietal. A média de erros para o ensaio B foi de 3,0\%, mas foram observados valores de até 8,8\%, no tratamento com $5 \%$ de misturas (T10). Para o ensaio A ( $L 1$ e L2), a média de erros foi de $4,8 \%$, mas foram observados valores de $16,8 \%$ em um dos tratamentos, demonstrando que as diferenças entre as sementes dessas linhagens foram menos marcantes que as observadas para L3 e L4.

A consistência nos resultados diminuiu com a redução no número de sementes contaminantes de cada amostra. Assim, as maiores variações nas porcentagens de acerto foram obtidas para amostras com 1 e $2 \%$ de contaminação, enquanto nas misturas com 5 e 10\% houve tendência de 
aumento na porcentagem de acertos, em ambos os ensaios. Esses dados demonstram que a avaliação de pureza varietal mediante o uso apenas de características morfológicas de sementes pode levar a resultados menos seguros quando, no lote, a contaminação com outros genótipos for inferior a $2 \%$.

Tendo em vista que o padrão para comercialização de sementes básicas de milho não admite contaminação com sementes de outras espécies e cultivares (CATI,1999), a não identificação de níveis menos intensos de contaminação, como $1 \%$, pode conduzir a ineficiência na avaliação da qualidade do lote e prejudicar a decisão quanto ao seu destino final. Portanto, os testes para detecção de mistura varietal devem identificar níveis mínimos de contaminação para serem recomendados com segurança.

\subsubsection{Avaliação de plântulas}

A pureza varietal dos lotes de linhagens de milho também foi avaliada através da observação de descritores morfológicos de plântulas. As características observadas para cada linhagem encontram-se no Quadro 2. e podem ser visualizadas na Figura 3. Verificou-se que a pigmentação com antocianina em várias partes das plântulas foi uma característica decisiva para diferenciar L1 de L2 e L3 de L4; assim, L2 apresentou coloração intensa tanto no coleoptilo como na borda da margem da folha, não sendo observado o mesmo em L1. Por outro lado, L4 apresentou pigmentação com antocianina na nervura central da primeira folha desenvolvida, enquanto em L3 esse pigmento esteve presente somente na bainha foliar. A intensidade da coloração verde e a forma da extremidade da primeira folha verdadeira, também, foram utilizadas na distinção das linhagens, sendo a intensidade de coloração consideravelmente diferente entre L3 e L4 e, a forma pontiaguda da extremidade da folha de L1, de grande utilidade para diferenciá-la de L2. 
Os resultados obtidos com o uso de características morfológicas de plântulas, para detecção de contaminantes, encontram-se na Tabela 7. Em ambos os ensaios as amostras foram identificadas com 100\% de acerto apenas para os tratamentos sem misturas (T1, T6, T7 e T12). Esses resultados demonstram a dificuldade de identificação dos genótipos, pela análise de características morfológicas de plântulas, pois, freqüentemente, o desenvolvimento dessas pode não corresponder ao padrão esperado, conduzindo ao reconhecimento equivocado do cultivar e à classificação incorreta das plântulas. Também, Ditmer (1979) e Schimidt (1979) observaram que análises baseadas em descritores morfológicos de plântulas podem ser imprecisas, devido à interação das plântulas com o ambiente. Variações na intensidade da pigmentação com antocianina e da sua distribuição nas partes da planta são observadas, assim como alterações na intensidade da coloração verde e estiolamento, devido a ausência de luminosidade durante a condução do teste. Isso pode conduzir à descaracterização das plântulas e dificultar a sua comparação com padrões de referência. 

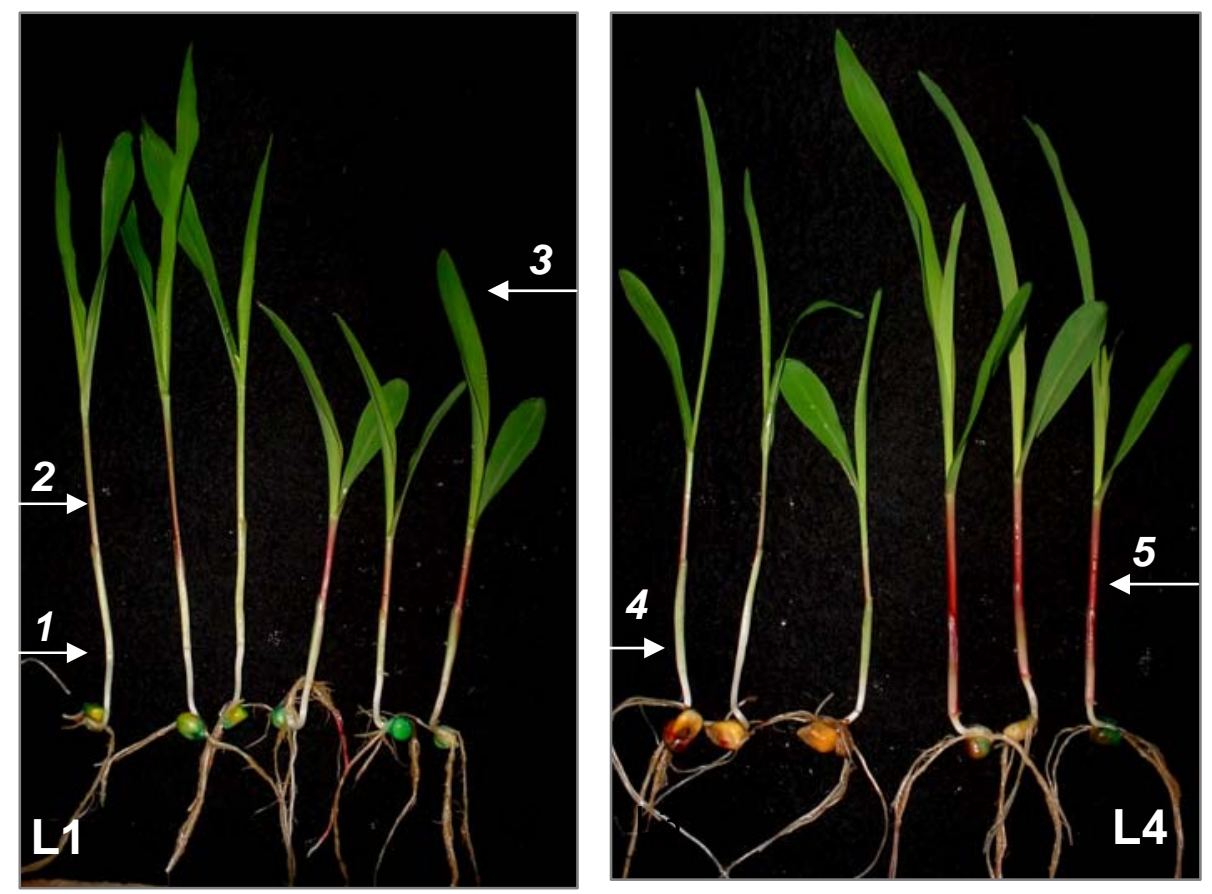

Figura 3 - À esquerda, plântulas das linhagens de milho L1 e L2 (ensaio A) e a direita plântulas de L3 e L4 (ensaio B). Em 1 e 2- observa-se ausência de pigmentação com antocianina no coleoptilo e pigmentação fraca na bainha foliar das plântulas de L1; 3- forma arredondada da extremidade da folha de L2; 4- coleoptilo incolor e folha verde escuro em L3 e 5- a presença intensa de antocianina na bainha foliar de L4
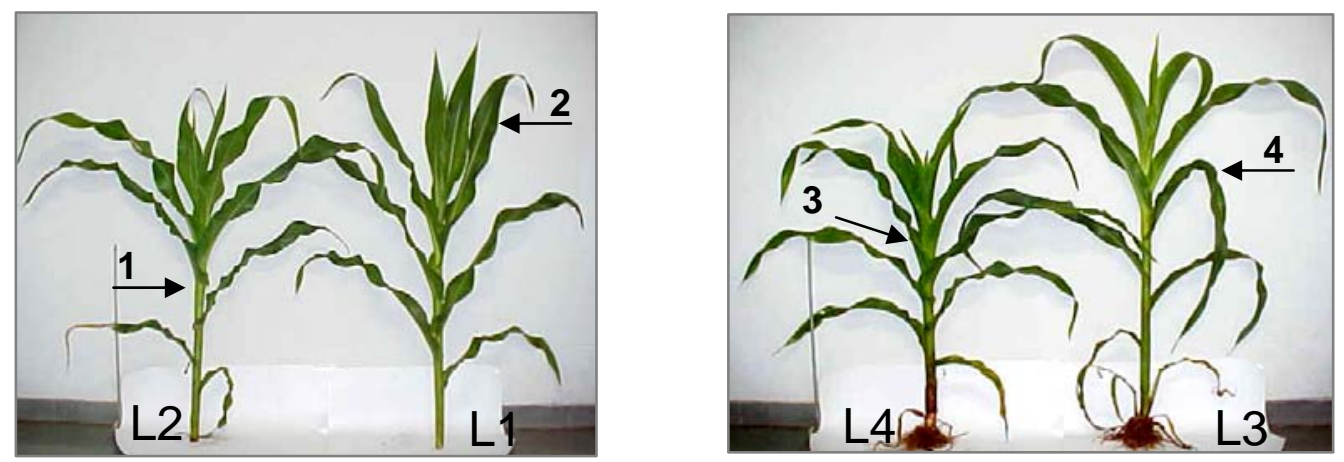

Figura 4 - À esquerda plantas das linhagens de milho L1 e L2 (ensaio A) e a direita plantas de L3 e L4 (ensaio B). Em 1- observa-se entrenós longos em L2; 2- folhas eretas e pontiagudas em L1; 3- entrenós curtos e antocianina na base do colmo em L4; 4- folhas recurvadas, arredondadas e estreitas em L3 
Tabela 7. Resultados percentuais de acerto e erro na avaliação da pureza varietal de linhagens de milho (com diferentes proporções de contaminação) através da avaliação de características morfológicas de plântulas

\begin{tabular}{|c|c|c|c|c|c|}
\hline $\begin{array}{l}\text { Ensaio A } \\
\text { Tratamentos } \\
(\text { L1 - L2) }\end{array}$ & Acerto & Erro & $\begin{array}{c}\text { Ensaio B } \\
\text { Tratamentos } \\
\text { (L3 - L4) }\end{array}$ & Acerto & Erro \\
\hline $\mathrm{T} 1$ & $100,0 \pm 0,0$ & $0,0 \pm 0,0$ & $\mathrm{~T} 7$ & $100,0 \pm 0,0$ & $0,0 \pm 0,0$ \\
\hline T2 & $75,0 \pm 17,7$ & $25,0 \pm 25,0$ & T8 & $100,0 \pm 0,0$ & $1,7 \pm 1,5$ \\
\hline T3 & $83,0 \pm 7,2$ & $17,0 \pm 7,4$ & T9 & $87,5 \pm 12,5$ & $12,8 \pm 12,8$ \\
\hline T4 & $73,3 \pm 17,6$ & $28,1 \pm 18,5$ & T10 & $95,0 \pm 5,0$ & $5,3 \pm 5,3$ \\
\hline T5 & $57,5 \pm 0,0$ & $47,2 \pm 0,0$ & T11 & $85,8 \pm 1,4$ & $15,7 \pm 1,6$ \\
\hline T6 & $100,0 \pm 0,0$ & $0,0 \pm 0,0$ & T12 & $100,0 \pm 0,0$ & $0,0 \pm 0,0$ \\
\hline
\end{tabular}

As porcentagens de acerto variaram de 57,5 a $83,3 \%$, com média de $81,4 \%$, para os tratamentos contendo as misturas no ensaio A (L1 - L2), enquanto a identificação dos tratamentos com misturas no ensaio B (L3 e L4) variou de 85,8 a 100\%, com média de 94,7\%. Von Pinho (1995) também observou variação na porcentagem de acertos (37,5 a 90\%) na identificação de genótipos contaminantes em lotes de híbridos, através da análise de plântulas, comprovando que materiais morfologicamente semelhantes são mais difíceis de serem separados por esse método. Nos casos em que as plântulas diferiam quanto à intensidade da pigmentação de antocianina na bainha e na nervura central da primeira folha, a eficiência na identificação atingiu 90\%; porém em nenhum dos tratamentos houve $100 \%$ de acerto.

Também trabalhando com sementes híbridas, Salgado (2001) conseguiu identificar $100 \%$ das plântulas provenientes da linhagem feminina autofecundada, em amostras do híbrido UFLA7/4, através da observação de características morfológicas. Porém, para o híbrido UFLA8/3, houve erro de $13 \%$, resultante da dificuldade na identificação das plântulas contaminantes, 
demonstrando que a eficiência do uso de testes baseados em descritores de plântulas varia com os genótipos.

As menores porcentagens de acerto foram observadas nos tratamentos contendo taxas elevadas de misturas em ambos os ensaios, ou seja, com $10 \%$ de sementes contaminantes (T5 e T11); os erros também foram elevados nesses tratamentos, alcançando $47,2 \%$ na mistura entre L1 e L2. Portanto, a eficiência na identificação de contaminantes é reduzida com aumento no número de sementes contaminantes na amostra. Maiores índices de erros eram esperados em amostras contendo menor número de sementes, onde existem possibilidades elevadas de não se identificar sementes contaminantes, uma vez que podem surgir dúvidas com relação a variabilidade morfológica dentro do genótipo. Por outro lado, o aumento no número de sementes contaminantes pode elevar a tendência do analista em classificar sementes puras, que se encontrem um pouco fora dos padrões de referência, como contaminantes.

Comparando os resultados obtidos para a avaliação morfológica de sementes e plântulas, observou-se que a média de acertos entre os tratamentos foi de 95,3 e 97,1\%, para amostras de L1 e L2 e de L3 e L4, respectivamente, na análise de amostras de sementes, enquanto para plântulas os valores observados foram de $81,5 \%$ e 94,7\%. A avaliação de sementes foi $14 \%$ superior em acertos à de pântulas, na detecção de contaminantes em misturas de L1 e L2 (ensaio A) e, 2,5\% maior para L3 e L4 (ensaio B). Portanto, para os genótipos L1 e L2, a análise de plântulas foi menos eficiente que a de sementes, com média de erros de 19,6\%, e confirma que o uso de marcadores morfológicos deve ser feito com critério pois, dependendo do cultivar em análise, deve-se optar pela avaliação em um ou mais estádios de desenvolvimento. Quando a discriminação segura entre cultivares distintos pode ser realizada em sementes, há vantagem de economia de tempo, espaço e custo, acelerando a obtenção de resultados e decisão a respeito do destino do lote. 
Testou-se, também, um método com mensuração direta de parâmetros, procurando identificar misturas de genótipos por meio do desempenho ou vigor de plântulas. Na Tabela 8 são apresentados os resultados médios do comprimento total e da parte aérea de plântulas. Por este método não foi possível identificar misturas de sementes dentro das amostras testadas, tanto no ensaio $A$ como no $B$, pois mesmo com o aumento nas proporção de plântulas contaminantes a média dos tratamentos contendo misturas não se alterou.

No ensaio A (L1 - L2) foi observada diferença estatística apenas no parâmetro comprimento da parte aérea de plântula, sem resultado significativo para comprimento total de plântula. A menor média foi verificada no tratamento contendo $100 \%$ de plântulas de L2 (T6); porém, este não diferiu significativamente de T1, com 100\% de plântulas de L1 (consideradas puras). Dessa forma, não foi possível separar as plântulas contaminantes (L2) das puras (L1), nos tratamentos com diferentes níveis de mistura.

Tabela 8. Resultados médios do comprimento da parte aérea de plântulas (CPA) e do comprimento total de plântulas (CTP) de amostras com diferentes proporções entre as linhagens de milho

\begin{tabular}{ccccccc}
\hline $\begin{array}{c}\text { Ensaio A } \\
\begin{array}{c}\text { Tratamentos } \\
(\text { L1 - L2 })\end{array}\end{array}$ & $\begin{array}{c}\text { CPA } \\
(\mathrm{cm})\end{array}$ & $\begin{array}{c}\text { CTP } \\
(\mathrm{cm})\end{array}$ & & $\begin{array}{c}\text { Ensaio B } \\
\text { Tratamentos } \\
\text { (L3 }- \text { L4 })\end{array}$ & $\begin{array}{c}\text { CPA } \\
(\mathrm{cm})\end{array}$ & $\begin{array}{c}\text { CTP } \\
(\mathrm{cm})\end{array}$ \\
\hline T1 & $19,5 \mathrm{ab} \mathrm{b}^{1}$ & $47,7 \mathrm{a}$ & & T7 & $22,0 \mathrm{a}$ & $49,6 \mathrm{a}$ \\
T2 & $18,6 \mathrm{ab}$ & $45,9 \mathrm{a}$ & & T8 & $22,2 \mathrm{a}$ & $49,3 \mathrm{a}$ \\
T3 & $20,9 \mathrm{ab}$ & $47,7 \mathrm{a}$ & & T9 & $22,8 \mathrm{a}$ & $49,2 \mathrm{a}$ \\
T4 & $21,0 \mathrm{a}$ & $47,0 \mathrm{a}$ & & T10 & $22,3 \mathrm{a}$ & $49,8 \mathrm{a}$ \\
T5 & $19,6 \mathrm{a}$ & $45,0 \mathrm{a}$ & & T11 & $22,9 \mathrm{a}$ & $50,7 \mathrm{a}$ \\
T6 & $18,3 \mathrm{~b}$ & $46,0 \mathrm{a}$ & & T12 & $18,5 \mathrm{~b}$ & $46,6 \mathrm{~b}$ \\
CV. $(\%)$ & 5,8 & 4,5 & & CV. $(\%)$ & 2,4 & 1,6 \\
\hline
\end{tabular}

${ }^{1}$ Médias seguidas de mesma dentro de cada coluna não diferem entre si pelo teste de Tukey; $p \leq 0,05$. 
No ensaio B (L3 - L4), observou-se diferença estatística para as variáveis comprimento total e da parte aérea de plântulas, entre o tratamento com 100\% de plântulas contaminantes L4 (T12) e os demais. Esse foi significativamente inferior ao tratamento contendo $100 \%$ de plântulas L3 (T7) e, também, a todos os demais níveis de mistura avaliados. Nem mesmo com 10\% de plântulas contaminando a amostra (T11), foi verificada alteração na média. Isso indica, provavelmente, que índices superiores de contaminação são necessários para que a média se altere ou que esse parâmetro não seja eficiente em diferenciar genótipos, quando se utiliza a média entre tratamentos. Neste caso, valores discrepantes podem ser computados como erro experimental, resultante do acaso, e não interferem na média final, aumentando apenas o desvio padrão.

Uma vez que o desenvolvimento de uma plântula resulta da interação genótipo com ambiente, mesmo controlando-se cuidadosamente a temperatura, a luminosidade e a disponibilidade de água, podem ocorrer variações em algum desses componentes que ocasionam alterações no fenótipo das plântulas (Ditmer, 1979; Schimidt, 1979), como comprimento da parte aérea, das raízes e espessura de colmo. Embora, em princípio, o uso de uma característica mensurável dê a impressão de menor interferência do analista no resultado final, dependendo do descritor e do estádio de desenvolvimento da planta em que se processa essa mensuração, a precisão pode ser afetada. Portanto, a escolha de outros marcadores morfológicos, menos instáveis, talvez ofereça maior confiabilidade na análise.

Da mesma forma que a análise de parâmetros mensuráveis sofre interferência do ambiente, a avaliação visual de características morfológicas pode ser influenciada tanto por fatores externos como pelo analista. Para verificar se houve interferência dos observadores na avaliação, foi realizado o teste do qui-quadrado, cujos resultados encontram-se na Tabela 9. Não houve significância dos desvios entre os dados obtidos pelos três avaliadores, para a análise de sementes e plântulas, indicando que os erros ocorreram ao 
acaso. Apenas o tratamento T5 (10\% de contaminação) apresentou valor significativo no desvio, indicando que houve erro por parte dos avaliadores na identificação das misturas. Assim, o uso de características morfológicas de plântulas pode não ser eficiente para alguns cultivares devido a dificuldade na identificação de diferenças marcantes entre genótipos.

Os baixos valores de qui-quadrado, com resultados não significativos, juntamente com as baixas porcentagens de erro (Tabela 9), indicam ser possível a identificação de misturas varietais através da avaliação de características morfológicas de sementes e, com certo cuidado, também de plântulas. Porém, o nível de detecção tanto para sementes como para plântulas é pouco confiável, o que exige a condução do ciclo da cultura até estádios mais avançados para a confirmação dos resultados e decisão quanto ao destino do lote em análise. 
Tabela 9. Resultados do teste do qui-quadrado $\left(\gamma^{2}\right)$ aplicado aos dados obtidos por três observadores (Obs) para a identificação de contaminações entre as linhagens de milho, através da observação de características morfológicas de sementes e plântulas

\begin{tabular}{|c|c|c|c|c|c|c|c|c|}
\hline \multirow{2}{*}{$\begin{array}{c}\text { Ensaio A } \\
\text { Tratamentos } \\
\text { L1 - L2 }\end{array}$} & \multicolumn{4}{|c|}{ Avaliação de sementes } & \multicolumn{4}{|c|}{ Avaliação de plântulas } \\
\hline & Obs.01 & Obs.02 & Obs.03 & $\gamma^{2}$ & Obs.01 & Obs.02 & Obs.03 & $\gamma^{2}$ \\
\hline $\mathrm{T} 1$ & 0,000 & 0,000 & 0,000 & $0,000^{\text {n.s. }}$ & 0,000 & 0,000 & 0,000 & $0,000^{\text {n.s. }}$ \\
\hline $\mathrm{T} 2$ & 0,063 & 0,063 & 0,063 & $0,189^{\text {n.s. }}$ & 1,563 & 0,563 & 0,063 & $2,189^{\text {n.s. }}$ \\
\hline T3 & 0,031 & 1,531 & 0,281 & $1,843^{\text {n.s. }}$ & 0,281 & 0,781 & 0,281 & $1,343^{\text {n.s. }}$ \\
\hline $\mathrm{T} 4$ & 0,113 & 0,313 & 0,113 & $0,539^{\text {n.s. }}$ & 0,313 & 1,513 & 4,513 & $6,339^{\text {n.s. }}$ \\
\hline T5 & 0,156 & 0,306 & 0,006 & $0,468^{\text {n.s. }}$ & 7,656 & 7,656 & 7,656 & $22,968^{\star \star}$ \\
\hline T6 & 0,031 & 0,031 & 0,001 & $0,063^{\text {n.s. }}$ & 0,031 & 0,181 & 0,001 & $0,213^{\text {n.s. }}$ \\
\hline $\begin{array}{c}\text { Ensaio B } \\
\text { Tratamentos } \\
\text { L3 - L4 }\end{array}$ & Obs.01 & Obs.02 & Obs.03 & $\gamma^{2}$ & Obs.01 & Obs.02 & Obs.03 & $\gamma^{2}$ \\
\hline $\mathrm{T} 7$ & 0,000 & 0,000 & 0,000 & $0,000^{\text {n.s. }}$ & 0,000 & 0,000 & 0,000 & $0,000^{\text {n.s. }}$ \\
\hline T8 & 0,563 & 0,063 & 0,063 & $0,689^{\text {n.s. }}$ & 0,063 & 0,063 & 0,063 & $0,189^{\text {n.s. }}$ \\
\hline T9 & 0,031 & 0,031 & 0,031 & $0,093^{\text {n.s. }}$ & 0,031 & 0,781 & 0,281 & $1,093^{\text {n.s. }}$ \\
\hline $\mathrm{T} 10$ & 0,013 & 0,113 & 1,013 & $1,139^{\text {n.s. }}$ & 0,113 & 0,013 & 0,313 & $0,439^{\text {n.s. }}$ \\
\hline $\mathrm{T} 11$ & 0,006 & 0,056 & 0,006 & $0,068^{\text {n.s. }}$ & 0,756 & 1,056 & 1,056 & $2,868^{\text {n.s. }}$ \\
\hline $\mathrm{T} 12$ & 0,001 & 0,001 & 0,001 & $0,003^{\text {n.s. }}$ & 0,001 & 0,001 & 0,001 & $0,003^{\text {n.s. }}$ \\
\hline
\end{tabular}

n.s. -não significativo

** - significativo ao nível de $1 \%$ de probabilidade. 


\subsubsection{Avaliação de plantas em campo}

Os resultados da avaliação morfológica de plantas em diferentes estádios de desenvolvimento, com base nos descritores selecionados (Quadro 3), permitiram a identificação de mistura varietal em lotes de sementes de linhagens de milho, com porcentagens variadas de acerto para as misturas com as linhagens L1 e L2 (ensaio A) e com L3 e L4 (ensaio B), tanto no experimento conduzido em Cravinhos-SP, como em Piracicaba-SP.

Para o experimento conduzido em Cravinhos - SP verificou-se que a pigmentação com antocianina do coleóptilo, nervura central e borda da lâmina foliar não foi suficiente para distinguir as linhagens, com segurança, em ambos os ensaios. Por outro lado, a presença desse pigmento na bainha foliar, permitiu diferenciar L3 de L4 no ensaio $B$, com eficiência, pois em L4 sua presença foi intensa e ausente em L3. Entre as demais características selecionadas, a forma da extremidade e a posição da última folha completamente desenvolvida em relação ao colmo foram decisivas para distinguir L1 de L2 (ensaio A). Em L1 a extremidade era pontiaguda e a posição era ereta em relação ao colmo, contrastando com a forma arredondada e posição recurvada de L2. A intensidade de coloração verde da folha foi outra característica que diferenciou as plantas no ensaio B, uma vez que L3 apresentou cor verde escuro que contrastou com o verde claro de L4.

Em condições de campo foi mais difícil avaliar características morfológicas em plântulas (estádio zero), comparativamente às análise feitas em laboratório. Entre os fatores que contribuíram para a menor eficiência e maior dificuldade em separar genótipos das plântulas em campo destacam-se: a impossibilidade de retirar a plântula do solo para uma avaliação minuciosa, a posição desconfortável do analista durante a análise e a não utilização de equipamentos como lupa e bisturi e do uso de superfície branca para auxiliar a observação de contrastes e intensidade de cores. As médias de acerto observadas para L1 e 
L2 e para L3 e L4, nesse estádio, foram de $66,7 \%$ e $74,9 \%$, respectivamente. No estádio 1, por outro lado, as plantas encontravam-se mais desenvolvidas e possibilitaram a avaliação mais segura, em relação à realizada no estádio zero; nessa situação, foram observadas média de acertos de $88,3 \%$, para os tratamentos do ensaio A e $87,1 \%$, para o ensaio $\mathrm{B}$.

Não foram realizadas avaliações posteriores ao estádio 1, nesse experimento, devido a problemas enfrentados com o manejo da cultura, como alta incidência da lagarta do cartucho (Spodoptera frugiperda) e dificuldades para seu controle, que inviabilizaram a identificação segura de caraterísticas morfológicas das plantas, nos demais estádios subsequentes.

Para o experimento conduzido em Cravinhos - SP, a média de acertos foi de $77,5 \%$ nos tratamentos com as linhagens L1 e L2 (ensaio A) e de $81 \%$ para L3 e L4 (ensaio B). A maior porcentagem de acertos observada no ensaio B ocorreu devido a diferenças morfológicas marcantes entre as linhagens, o que não se verificou para L1 e L2.

Quando se considerou o estádio de desenvolvimento, houve aumento na porcentagem de acertos do estádio zero para o estádio 1, tanto para L1 e L2, como para L3 e L4. Isso resulta da maior dificuldade de avaliação de plântulas em campo (estádio zero). Von Pinho et al. (1997) afirmaram que a escolha do estádio de desenvolvimento da cultura para a análise da pureza genética e varietal depende da possibilidade de identificação segura das características morfológicas e, também, da rapidez necessária para obtenção dos resultados ou para a aferição do trabalho de despendoamento nos campos de produção, no caso de híbridos.

Com relação aos diferentes níveis de mistura testados (Tabela 10) nota-se que não houve tendência de aumento ou redução na porcentagem de acertos, com o aumento na taxa de contaminantes nas amostras. Verificou-se $100 \%$ de acerto na identificação de plantas contaminantes, no estádio 1 , nos tratamentos contendo $2 \%$ de contaminação (T3), para o ensaio A (L1 - L2) e nos tratamentos com 1 e 2\% de contaminação, para o ensaio B (L3 - L4. Porém, ao 
mesmo tempo em que esses valores foram alcançados, no tratamento com $1 \%$ de contaminação com L2 (T2), para o ensaio A, a porcentagem de erro foi de $50 \%$, sendo a maior observada nessa avaliação. Para o ensaio $B, a$ contaminação com 5\% de L4 (T10) foi a que proporcionou a maior taxa de erros $(66,1 \%)$. Portanto, a eficiência na identificação depende diretamente dos cultivares que constituem a mistura de sementes. Cultivares morfologicamente distintos podem ser mais facilmente identificados e separados em análises feitas por observação direta, em relação às sementes com semelhança física. Nesse contexto, não foi possível identificar a partir de que nível de contaminação a eficiência na identificação de contaminantes começa a ser reduzida.

Assim, com base nos dados obtidos nesse experimento, verificou-se que a avaliação da pureza varietal de lotes de linhagens de milho, durante os estádios zero e 1, não foi suficiente para detectar com segurança todos os contaminantes presentes. As conclusões obtidas com base na análise podem sub ou superestimar a contaminação real do lote, alterando as decisões tomadas durante o programa de controle de qualidade. 
Tabela 10. Porcentagens de acerto e erro na avaliação da pureza varietal de linhagens de milho por meio de marcadores morfológicos observados nos estádios zero e 1, com simulação de contaminações de lotes de sementes das linhagens puras L1 e L3, com porcentagens variadas das linhagens L2 e L4 (1, 2, 5 e 10\%). Experimento realizado em Cravinhos - SP

\begin{tabular}{|c|c|c|c|c|c|c|c|c|c|}
\hline \multirow{2}{*}{$\begin{array}{c}\text { Ensaio A } \\
\text { Tratamentos } \\
(\mathrm{L} 1-\mathrm{L} 2)\end{array}$} & \multicolumn{2}{|c|}{ Estádio zero } & \multicolumn{2}{|c|}{ Estádio 1} & \multirow{2}{*}{$\begin{array}{l}\text { Ensaio B } \\
\text { Tratamentos } \\
\text { (L3 - L4) }\end{array}$} & \multicolumn{2}{|c|}{ Estádio zero } & \multicolumn{2}{|c|}{ Estádio 1} \\
\hline & Acerto & Erro & Acerto & Erro & & Acerto & Erro & Acerto & Erro \\
\hline $\mathrm{T} 1$ & $100,0 \pm 0,0$ & $0,0 \pm 0,0$ & $100,0 \pm 0,0^{*}$ & $0,0 \pm 0,0$ & T7 & $100,0 \pm 0,0$ & $0,0 \pm 0,0$ & $100,0 \pm 0,0^{*}$ & $0,0 \pm 0,0$ \\
\hline $\mathrm{T} 2$ & $58,3 \pm 31,9$ & $42,0 \pm 32,2$ & $50,0 \pm 57,7$ & $50,0 \pm 57,7$ & T8 & $66,7 \pm 22,7$ & $33,7 \pm 27,4$ & $100,0 \pm 0,0$ & $0,0 \pm 0,0$ \\
\hline T3 & $50,0 \pm 19,3$ & $51,1 \pm 19,7$ & $100,0 \pm 0,0$ & $0,0 \pm 0,0$ & T9 & $66,7 \pm 30,4$ & $34,0 \pm 31,1$ & $100,0 \pm 0,0$ & $0,0 \pm 0,0$ \\
\hline T4 & $55,0 \pm 17,3$ & $47,4 \pm 18,5$ & $90,0 \pm 11,6$ & $10,5 \pm 12,2$ & $\mathrm{~T} 10$ & $55,0 \pm 19,2$ & $43,5 \pm 16,2$ & $40,0 \pm 20,0$ & $66,1 \pm 44,1$ \\
\hline T5 & $36,7 \pm 11,9$ & $70,6 \pm 12,9$ & $90,0 \pm 8,2$ & $11,1 \pm 9,1$ & $\mathrm{~T} 11$ & $60,8 \pm 14,5$ & $43,5 \pm 16,2$ & $82,5 \pm 23,6$ & $19,5 \pm 26,3$ \\
\hline T6 & $100,0 \pm 0,0$ & $0,0 \pm 0,0$ & $100,0 \pm 0,0$ & $0,0 \pm 0,0$ & T12 & $100,0 \pm 0,0$ & $0,0 \pm 0,0$ & $100,0 \pm 0,0$ & $0,0 \pm 0,0$ \\
\hline
\end{tabular}

* - Desvio padrão da média.

Estádio zero - corresponde ao período da semeadura até duas folhas completamente desdobradas e

Estádio 1 - corresponde a plantas com quatro folhas totalmente desdobradas. 
Devido a problemas relacionados a tratos culturais enfrentados no experimento realizado em Cravinhos-SP, optou-se pela instalação de outro experimento em área da ESALQ, em Piracicaba-SP. Com base nas características morfológicas observadas em cada linhagem (Quadro 3), foi possível avaliar a pureza varietal dos lotes em vários estádios de desenvolvimento, sendo que dentro de cada estádio, a porcentagem de acertos e erros na identificação de contaminantes (Tabelas 11 e 12) variou conforme a taxa de contaminação (0 a 100\%). Verificou-se que a porcentagem de acertos foi aumentando a medida que as plantas foram se desenvolvendo, alcançando porcentagens máximas nos estádios onde estas foram diferenciadas por características de estruturas reprodutivas. O estádio zero deixou de ser avaliado, a partir do experimento conduzido em Cravinhos - SP, quando constatou-se que a análise de plântulas em laboratório oferecia maior confiabilidade.

As características que permitiram a identificação mais segura e rápida das linhagens L1 e L2 (ensaio A), nos estádios 1 a 3, foram a forma da extremidade e posição de inserção da última folha completamente desenvolvida. L1 caracterizou-se pela folha com extremidade pontiaguda e posição ereta em relação ao colmo (Figura 4), enquanto em L2 as folhas mostraram-se arredondadas e recurvadas, além da pubescência abundante e pigmentação intensa com antocianina das raízes adventícias aéreas. Para L3 e L4 (ensaio B), a intensidade da coloração verde da folha e a pigmentação com antocianina em elevada intensidade na bainha foliar, foram as características principais que distinguiram as plantas dessas linhagens em populações misturadas.

Nas avaliações realizadas nos estádios 1 a 3 , para o ensaio $A$, a porcentagem de acertos só alcançou o nível de 100\% nos tratamentos contendo exclusivamente plantas de L1 (T1) ou as contaminantes L2 (T2). Em todas as demais misturas não foi possível identificar todas as plantas contaminantes de cada tratamento, sendo que os erros de avaliação variaram de 34,7 a $84,7 \%$. Assim, não se recomenda a determinação da pureza varietal 
dessas linhagens nesses estádios de desenvolvimento. Também para o ensaio B a taxa de $100 \%$ de acerto na identificação de plantas foi alcançada nos tratamentos com 100\% de plantas de L3 (T7) e L4 (T12), com mesmo resultado verificado no tratamento com $1 \%$ de mistura de L4 (T8), avaliado no estádio 3. Os demais tratamentos não foram identificados com 100\% de acertos; porém, os índices de erros foram inferiores aos observados no ensaio $A$, com valor máximo de 50,6\% e mínima taxa de acerto de 50\%. Portanto, para essas linhagens (L3 e L4) as avaliações foram mais eficientes, mas não satisfatórias.

No estádio 4 (plantas com todas as folhas desenvolvidas e emissão do pendão) houve aumento na porcentagem de acertos na identificação de plantas, tanto no ensaio A, com L1 e L2 (Tabela 11), como no ensaio B contendo L3 e L4 (Tabela 12). Os valores de acerto variaram de 67,5 a 100\% para o ensaio $A$ e não foram inferiores a $88,8 \%$ para o ensaio $B$. A diferenciação mais segura no ensaio A ocorreu devido à observação de características como menor distância entrenós, coloração verde escura, ausência de curvatura do colmo e menor comprimento do pendão de L1,em relação a L2. Houve menor índice de erros nesse estádio de avaliação, em relação aos demais, com máximo de 37,2\% para L1 e L2 e 12,2\% para L3 e L4. Índice de $100 \%$ de acerto foi obtido em vários tratamentos para a avaliação realizada no estádio 4 e as plantas de L3 e L4 foram mais eficientemente identificada do que às de L1 e L2. A facilidade de distinção entre L3 e L4, através da observação do número de internódios do colmo e comportamento das ramificações laterais do pendão, pode ter contribuído para maior porcentagem de acertos na identificação dessas plantas, sendo que em L3 o número e a distância dos internódios foi maior que em $L 4$, com as ramificações laterais do pendão fortemente recurvadas em relação à haste principal, contrastando com a posição reta dessas estruturas em relação à haste principal, nas plantas de L4.

As maiores porcentagens de acerto foram verificadas no estádio 5 de desenvolvimento para ambos os ensaios (Tabelas 11 e 12). Esse estádio 
corresponde ao período de florescimento e polinização das plantas, com a exposição dos estilo-estigmas nas espigas e paralisação do alongamento do colmo e dos entrenós (Fancelli \& Dourado Neto, 2000). O aumento na porcentagem de acertos na identificação de plantas, nesse estádio, demonstra que os descritores mais eficientes na distinção desses cultivares foram observados no período reprodutivo da cultura, estando relacionados ao pendão e a espiga (Quadro 3). A média de acertos foi de 94,4\%, para o ensaio A, e de $97,9 \%$, para o ensaio B. As plantas da linhagem L1 apresentaram como características marcantes a presença de antocianina em alta intensidade nos estilo-estigmas e a posição ereta da espiga em relação ao colmo. L2 apresentou o comprimento da haste principal mais longo e a espiga em posição oblíqua. Estas características foram decisivas para a distinção das plantas durante a análise. Para L3 e L4, as diferenças quanto à presença de antocianina nas anteras, o comportamento das ramificações laterais do pendão e a posição da espiga na planta (Quadro 3) foram suficientemente marcantes para que, valores de 92,5 a $100 \%$ de acertos fossem observados. Entretanto, mesmo para o índice de $100 \%$ de acertos houve falhas na identificação de plantas. As plantas de L3 foram avaliadas como sendo contaminantes (L4) da amostra, contribuindo para a ocorrência de erro do tipo identificação equivocada. Esse tipo de erro demonstra que, ao mesmo tempo em que a presença de um contaminante pode não ser detectada pelo controle de qualidade, a classificação de uma planta típica do lote como contaminante também pode acontecer.

A coloração das anteras e do estigma é baseada na presença da antocianina, que é apontado como um pigmento com estabilidade pouco confiável para a identificação de cultivares (Srivastava \& Agrawa, 1985), devido à grande variação entre as partes da planta do milho, em função de alterações ambientais, como a luminosidade (Singh \& Sarkar, 1982) ou mesmo estresse causado por temperatura baixa. Essa característica não foi apontada como eficiente por Revilla \& Tarcy (1995) para distinguir plantas híbridas de seus 
parentais autofecundados. Por outro lado, Smith \& Smith (1989) observaram que a pigmentação com antocianina nas anteras e estigma é uma excelente característica para diferenciar genótipos, em função de sua repetibilidade em vários anos e locais. Da mesma forma, Von Pinho (1995) e Salgado (2001), obtiveram valores de $93,8 \%$ e $100 \%$ de acertos na identificação de plantas contaminantes em populações dos híbridos C 701 e UFLA7/4, respectivamente, quando foi utilizada a pigmentação com antocianina em anteras e no estigma das flores. Dessa maneira, é válida a utilização dessa caraterística como descritor fenotípico de milho, dependendo dos genótipos avaliados.

No estádio 8, verificou-se queda na porcentagem de acertos na identificação de plantas contaminantes, em relação ao estádio 5. Durante essa fase ocorre a senescência natural das plantas (Fancelli \& Dourado Neto, 2000), o que reduz a eficiência na identificação de características morfológicas que distinguem os materiais. Assim, as porcentagens de acertos observadas foram de $78,3 \%$ o ensaio A, e de $90,6 \%$ para o ensaio B. As características marcantes nessa avaliação foram a forma e a compactação da palha da espiga (Quadro 3), sugeridas por Pauskens (1975) como descritores eficientes para identificação de cultivares. Para L1 e L2, mesmo com elevada porcentagem de acerto, a ocorrência de erros alcançou $56,8 \%$ para o tratamento com $1 \%$ de contaminação (T2), considerado um índice elevado que demonstra a ineficiência da análise. 
Tabela 11. Porcentagens de acerto e erro na avaliação da pureza varietal de linhagens de milho (ensaio A) através de marcadores morfológicos observados em diferentes estádios fenológicos, com simulação de contaminações da linhagem pura L1 com porcentagens variadas da linhagem L2 (1, 2, 5 e 10\%). Experimento realizado em Piracicaba - SP

\begin{tabular}{|c|c|c|c|c|c|c|c|c|c|c|c|c|}
\hline \multirow{2}{*}{ Trat. } & \multicolumn{2}{|c|}{ Estádio $1^{1}$} & \multicolumn{2}{|c|}{ Estádio 2} & \multicolumn{2}{|c|}{ Estádio 3} & \multicolumn{2}{|c|}{ Estádio 4} & \multicolumn{2}{|c|}{ Estádio 5} & \multicolumn{2}{|c|}{ Estádio 8} \\
\hline & Acerto & Erro & Acerto & Erro & Acerto & Erro & Acerto & Erro & Acerto & Erro & Acerto & Erro \\
\hline $\mathrm{T} 1$ & $100,0 \pm 0,0^{*}$ & $0,0 \pm 0,0$ & $100,0 \pm 0,0$ & $0,0 \pm 0,0$ & $100,0 \pm 0,0$ & $0,0 \pm 0,0$ & $100,0 \pm 0,0$ & $0,0 \pm 0,0$ & $100,0 \pm 0,0$ & $0,0 \pm 0,0$ & $100,0 \pm 0,0$ & $0,0 \pm 0,0$ \\
\hline $\mathrm{T} 2$ & $25,0 \pm 28,9$ & $75,4 \pm 28.4$ & $37,5 \pm 25,0$ & $62,9 \pm 24,8$ & $62,5 \pm 25,0$ & $37,9 \pm 25,3$ & $100,0 \pm 0,0$ & $0,1 \pm 0,3$ & $100,0 \pm 0,0$ & $37,9 \pm 12,3$ & $75,0 \pm 28,9$ & $56,8 \pm 12,5$ \\
\hline T3 & $56,6 \pm 37,5$ & $44,3 \pm 37,2$ & $56,3 \pm 37,5$ & $44,1 \pm 37,3$ & $68,8 \pm 34,5$ & $34,4 \pm 36,8$ & $68,8 \pm 31,5$ & $31,9 \pm 31,1$ & $87,5 \pm 14,4$ & $24,1 \pm 20,8$ & $75,0 \pm 20,4$ & $50,3 \pm 35,2$ \\
\hline $\mathrm{T} 4$ & $17,5 \pm 28,7$ & $84,2 \pm 28,2$ & $17,5 \pm 28,7$ & $84,2 \pm 28,2$ & $30,0 \pm 18,3$ & $73,1 \pm 19,9$ & $67,5 \pm 20,6$ & $34,1 \pm 21,5$ & $85,0 \pm 12,9$ & $15,7 \pm 15,5$ & $52,5 \pm 5,0$ & $48,2 \pm 5,14$ \\
\hline T5 & $23,8 \pm 4,8$ & $84,7 \pm 5,3$ & $23,8 \pm 4,8$ & $84,7 \pm 5,3$ & $41,3 \pm 9,5$ & $65,3 \pm 10,5$ & $68,8 \pm 12,5$ & $37,2 \pm 17,9$ & $93,8 \pm 6,3$ & $9,7 \pm 5,4$ & $67,5 \pm 9,6$ & $33,0 \pm 9,4$ \\
\hline T6 & $100,0 \pm 0,0$ & $0,0 \pm 0,0$ & $100,0 \pm 0,0$ & $0,0 \pm 0,0$ & $100,0 \pm 0,0$ & $0,0 \pm 0,0$ & $100,0 \pm 0,0$ & $0,0 \pm 0,0$ & $100,0 \pm 0,0$ & $0,0 \pm 0,0$ & $100,0 \pm 0,0$ & $0,0 \pm 0,0$ \\
\hline $\begin{array}{l}{ }^{*} \text { - Desvi } \\
{ }^{1} \text { Estádic } \\
\text { Estádic } \\
\text { Estádic } \\
\text { Estádic } \\
\text { Estádic } \\
\text { Estádic }\end{array}$ & $\begin{array}{l}\text { padrão da me } \\
01 \text { - correspo } \\
02 \text { - correspo } \\
03 \text { - correspo } \\
04 \text { - correspo } \\
05 \text { - correspo } \\
08 \text { - correspo }\end{array}$ & $\begin{array}{l}\text { édia. } \\
\text { onde a plant } \\
\text { nde a plante } \\
\text { unde a planta } \\
\text { onde a plant } \\
\text { inde a planta } \\
\text { nde a plant }\end{array}$ & $\begin{array}{l}\text { tas com quat } \\
\text { tas com oito } \\
\text { tas com doze } \\
\text { tas com emis } \\
\text { tas em floresc } \\
\text { tas com grãos }\end{array}$ & $\begin{array}{l}\text { tro folhas tot } \\
\text { folhas totalm } \\
\text { folhas totalı } \\
\text { ssão de pen } \\
\text { cimento e po } \\
\text { s farináceos. }\end{array}$ & $\begin{array}{l}\text { talmente des } \\
\text { nente desdob } \\
\text { Imente desdo } \\
\text { Idão; } \\
\text { olinização e }\end{array}$ & $\begin{array}{l}\text { dobradas; } \\
\text { oradas; } \\
\text { obradas; }\end{array}$ & & & & & & \\
\hline
\end{tabular}


Tabela 12. Porcentagens de acerto e erro na avaliação da pureza varietal de linhagens de milho (ensaio B) através de marcadores morfológicos observados em diferentes estádios fenológicos, com simulação de contaminações da linhagem pura L3 com porcentagens variadas da linhagem L4 (1, 2, 5 e 10\%). Experimento realizado em Piracicaba - SP

\begin{tabular}{|c|c|c|c|c|c|c|c|c|c|c|c|c|}
\hline \multirow{2}{*}{ Trat. } & \multicolumn{2}{|c|}{ Estádio $1^{1}$} & \multicolumn{2}{|c|}{ Estádio 2} & \multicolumn{2}{|c|}{ Estádio 3} & \multicolumn{2}{|c|}{ Estádio 4} & \multicolumn{2}{|c|}{ Estádio 5} & \multicolumn{2}{|c|}{ Estádio 8} \\
\hline & Acerto & Erro & Acerto & Erro & Acerto & Erro & Acerto & Erro & Acerto & Erro & Acerto & Erro \\
\hline T7 & $100,0 \pm 0,0^{*}$ & )$^{*} 0,0 \pm 0,0$ & $100,0 \pm 0,0$ & $0,0 \pm 0,0$ & $100,0 \pm 0,0$ & $0,0 \pm 0,0$ & $100,0 \pm 0,0$ & $0,0 \pm 0,0$ & $100,0 \pm 0,0$ & $0,0 \pm 0,0$ & $100,0 \pm 0,0$ & $0,0 \pm 0,0$ \\
\hline T8 & $50,0 \pm 0,0$ & $50,6 \pm 0,3$ & $387,5 \pm 25,0$ & $12,6 \pm 25,3$ & $3100,0 \pm 0,0$ & $0,0 \pm 0,0$ & $100,0 \pm 0,0$ & $0,0 \pm 0,0$ & $100,0 \pm 0,0$ & $12,6 \pm 2,5$ & $87,5 \pm 25,0$ & $12,5 \pm 25,0$ \\
\hline T9 & $75,0 \pm 0,0$ & $25,6 \pm 0,3$ & $381,3 \pm 12,5$ & $19,3 \pm 12,5$ & $593,8 \pm 12,5$ & $6,4 \pm 12,5$ & $100,0 \pm 0,0$ & $0,0 \pm 0,0$ & $100,0 \pm 0,0$ & $19,3 \pm 24,2$ & $87,5 \pm 14,4$ & $19,4 \pm 14,4$ \\
\hline $\mathrm{T} 10$ & $65,0 \pm 25,2$ & $236,9 \pm 26,5$ & $577,5 \pm 26,3$ & $23,7 \pm 27,7$ & $787,5 \pm 9,6$ & $13,2 \pm 10,1$ & $95,0 \pm 10,0$ & $5,0 \pm 10,0$ & $95,0 \pm 10,0$ & $5,0 \pm 10,0$ & $85,0 \pm 12,9$ & $15,1 \pm 12,9$ \\
\hline T11 & $65,0 \pm 4,1$ & $43,9 \pm 13,9$ & $978,8 \pm 9,5$ & $28,6 \pm 7,2$ & $85,0 \pm 12,3$ & $19,2 \pm 14,5$ & $88,8 \pm 9,1$ & $12,2 \pm 9,1$ & $92,5 \pm 6,5$ & $10,4 \pm 10,9$ & $83,8 \pm 7,5$ & $16,6 \pm 7,4$ \\
\hline T12 & $100,0 \pm 0,0$ & $0,0 \pm 0,0$ & $100,0 \pm 0,0$ & $0,0 \pm 0,0$ & $100,0 \pm 0,0$ & $0,0 \pm 0,0$ & $100,0 \pm 0,0$ & $0,0 \pm 0,0$ & $100,0 \pm 0,0$ & $0,0 \pm 0,0$ & $100,0 \pm 0,0$ & $0,0 \pm 0,0$ \\
\hline
\end{tabular}

* - Desvio padrão da média.

${ }^{1}$ Estádio 01 - corresponde a plantas com quatro folhas totalmente desdobradas;

Estádio 02 - corresponde a plantas com oito folhas totalmente desdobradas;

Estádio 03 - corresponde a plantas com doze folhas totalmente desdobradas;

Estádio 04 - corresponde a plantas com emissão de pendão;

Estádio 05 - corresponde a plantas em florescimento e polinização e

Estádio 08 - corresponde a plantas com grãos farináceos. 
$\mathrm{Na}$ Figura 5, pode ser observado o comportamento das porcentagens de acerto na identificação de plantas contaminantes comparando-se os estádios de desenvolvimento do milho, em avaliações realizadas no experimento conduzido em Piracicaba - SP. Verificou-se que, estatisticamente, a avaliação realizada no estádio 5 não diferiu da observada no estádio 4, para a mistura com L1 e L2 e só diferiu dos estádios 1 e 2 para as misturas com L3 e L4. Porém, observase a tendência de aumento nos valores de acerto conforme as plantas se desenvolveram, com melhor desempenho no estádio 5, acompanhado de queda na eficiência com as plantas se aproximando do final do ciclo, devido à descaracterização da parte aérea com a senescência.

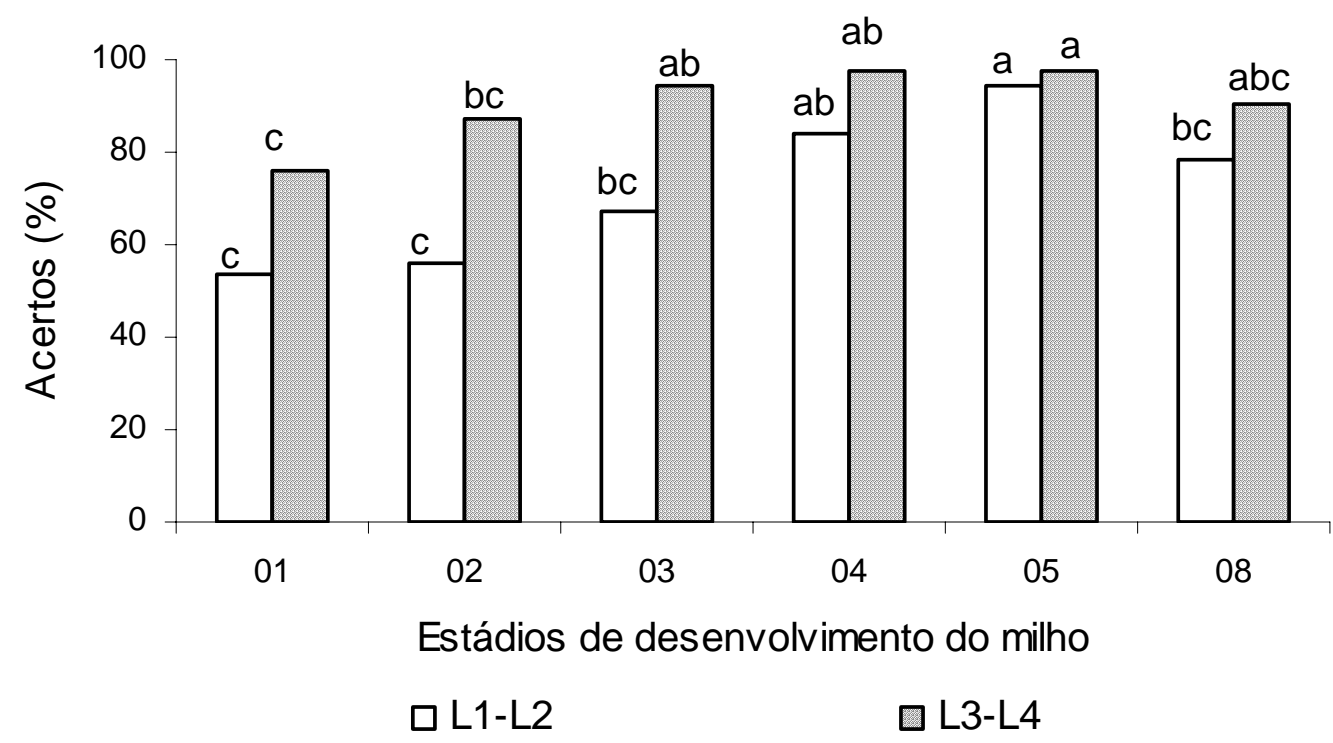

Figura 5 - Porcentagens médias de acertos na identificação de linhagens de milho, baseada em descritores morfológicos de plantas, observados em diferentes estádios de desenvolvimento da cultura. Experimento conduzido em Piracicaba -SP. Médias seguidas de mesma letra não diferem entre si em nível de $5 \%$ de significância pelo teste de Tukey 
A maior distinção morfológica entre L3 e L4 permitiu que as plantas dessa linhagem fossem identificadas com maior porcentagem de acertos logo no estádio 3, enquanto para L1 e L2 só foi possível a melhor diferenciação entre plantas a partir do estádio 4. Assim, para L3 e L4, a avaliação no estádio 3 apresentou eficiência razoável e a observação de características relacionadas à fase reprodutiva serviram para esclarecer possíveis dúvidas que surgiram nessa fase. Porém, deve ser ressaltado que, para nenhuma das misturas houve $100 \%$ de acertos em qualquer dos estádio avaliados, o que indica falhas na metodologia de determinação de pureza varietal de lotes através da observação de características morfológicas de plantas conduzidas em campo.

A proposta de uso do parâmetro altura de plantas para determinar a pureza varietal de lotes de sementes não foi confirmada (Tabela 13). Uma vez que, não se observaram alterações nas médias das amostras em decorrência da presença de contaminantes. Em ambos os ensaios houve diferença estatística apenas entre os tratamentos contendo $100 \%$ de plantas contaminantes (T6 e T12) e os demais, onde T6 apresentou média superior a verificada em outros tratamentos do ensaio A. A média de T12 foi inferior à da população com $100 \%$ de plantas de L3 e às demais misturas presentes no ensaio B. Von Pinho (1995), utilizando o parâmetro de altura de plantas para detectar misturas entre plantas híbridas e linhagens autofecundadas não obteve sucesso em análises com níveis de contaminação (plantas autofecundadas) inferiores a $20 \%$, mesmo com diferença aparente entre a altura das plantas híbridas e a dos contaminantes.

A análise do ângulo formado entre a lâmina foliar e o colmo foi outro parâmetro (Tabela 13) que não permitiu diferenciar os tratamentos constituídos por misturas de linhagens, daquele constituído, exclusivamente, pela linhagem considerada pura. Assim como para a altura de plantas, não foi possível identificar a presença de plantas contaminantes, através da alteração no valor da média dos tratamentos constituídos por misturas. Mesmo no ensaio $\mathrm{B}$, onde as plantas de L4 apresentaram menor ângulo de inserção da folha $\left(31^{\circ}\right)$, não foi 
observado o decréscimo na média. Somente o tratamento contendo $100 \%$ de L4, diferiu dos demais.

Esse parâmetro, juntamente com outras características morfológicas como cor de grão e de sabugo e forma da espiga não sofrem influência ambiental, de acordo com Revilla \& Tracy (1995), sendo portanto úteis em avaliações de misturas varietais e identificação de cultivares. Porém, a análise das plantas em grupo, não permitiu esse tipo de determinação. Talvez o uso desta informação, associada a outras características morfológicas marcantes, possa auxiliar a identificação de cultivares, mas o uso exclusivo desse parâmetro como identificador da presença de misturas de cultivares não é recomendado.

Tabela 13. Resultados médios da altura de plantas (AP) e ângulo de inserção de folha (AIF), de amostras de linhagens puras (L1, L3) e com diferentes níveis de contaminação $(1,2,5$, e 10\%) com outras linhagens (L2 e L4) de milho, obtidos em experimento realizado em Piracicaba-SP

\begin{tabular}{|c|c|c|c|c|c|}
\hline Ensaio A & & & Ensaio B & & \\
\hline $\begin{array}{c}\text { Tratamentos } \\
\text { L1 - L2 }\end{array}$ & $A P(m)$ & $\operatorname{AIF}\left({ }^{\circ}\right)$ & $\begin{array}{c}\text { Tratamentos } \\
\text { L3 - L4 }\end{array}$ & AP $(m)$ & $\operatorname{AIF}\left({ }^{\circ}\right)$ \\
\hline $\mathrm{T} 1$ & $1,50 \mathrm{~b}$ & $34 a$ & $\mathrm{~T} 7$ & $1,60 a$ & $46 a$ \\
\hline T2 & $1,48 b$ & $32 a$ & T8 & $1,53 a$ & $44 a$ \\
\hline T3 & $1,44 b$ & $34 a$ & T9 & $1,55 a$ & $45 a$ \\
\hline T4 & $1,51 b$ & $33 a$ & T10 & $1,58 \mathrm{a}$ & $45 a$ \\
\hline T5 & $1,49 b$ & $34 a$ & T11 & $1,48 a$ & $45 a$ \\
\hline T6 & $1,72 a$ & $34 a$ & T12 & $1,27 b$ & $31 b$ \\
\hline CV. (\%) & 3,56 & $5,9 a$ & CV. (\%) & 3,67 & 6,2 \\
\hline
\end{tabular}

${ }^{1}$ Médias seguidas de mesma dentro de cada coluna não diferem entre si pelo teste de Tukey; $\mathrm{p} \leq 0,05$. 
Comparando-se as avaliações (Figura 6) realizadas em sementes, plântulas e nas plantas que se encontravam no estádio 5 de desenvolvimento verificou-se que, para a mistura com L1 e L2 (ensaio A), a avaliação de plântulas foi a menos eficiente em distinguir as linhagens, enquanto para L3 e L4 (ensaio B) não foi verificada diferença entre as avaliações. Uma vez que a avaliação de sementes e de plantas adultas, com estruturas reprodutivas desenvolvidas, não diferiu estatisticamente, pode se recomendar o uso da observação de sementes para a diferenciação dessas linhagens, considerando-se que avaliações em estádios precoces reduzem o custo da análise. Porém, dependendo do genótipo em análise, como por exemplo, com semelhança morfológica entre sementes, a determinação segura da presença de sementes de outros cultivares só é possível mediante a condução do ciclo completo da cultura e para alguns genótipos nem essa avaliação é eficiente.

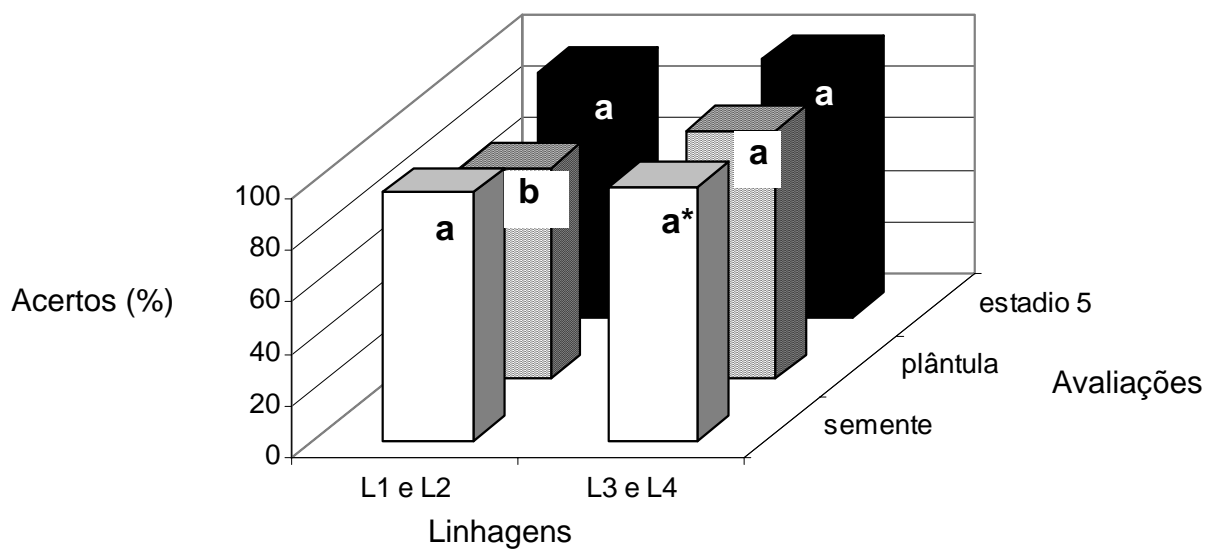

Figura 6 - Porcentagens médias de acertos na identificação de linhagens de milho, comparadas em função das avaliações realizadas nas sementes, plântulas e no estádio 5 de desenvolvimento da cultura (florescimento e polinização), em experimento conduzido em Piracicaba - SP. Médias seguidas de mesma letra não diferem entre si em nível de 5\% de significância pelo teste de Tukey 
De maneira geral, pode se afirmar que a determinação da pureza varietal de lotes de sementes através de marcadores morfológicos não oferece segurança suficiente para determinar a presença de contaminantes. Houve erros na identificação de contaminantes nas análises realizadas em sementes, plântulas e plantas, mesmo para linhagens que apresentavam distinção em várias características, indicando a baixa eficiência dessa metodologia, principalmente se forem consideradas cultivares semelhantes morfologicamente e a existência de variabilidade entre plantas de um mesmo genótipo. Dessa forma, o desenvolvimento de métodos alternativos, mais seguros, eficientes e rápidos, como os moleculares, são desejados e podem contribuir significativamente para o controle na qualidade mais eficiente dos lotes produzidos e multiplicados.

\subsection{Marcadores microssatélites}

\subsubsection{Tecido vegetal para extração de DNA}

A quantificação do DNA obtido tanto de amostras de misturas de sementes como de folhas de plântulas foi realizada em fluorímetro (Tabela 14) e em gel de agarose 0,8\% (Figuras 7 e 8 ). Verificou-se que as amostras de folhas de plântulas possibilitaram a extração de maior quantidade de DNA, em comparação às amostras de sementes, sendo que a média para sementes não ultrapassou 30ng. $\mu \mathrm{L}^{-1}$, enquanto os valores para folhas alcançaram 339ng. $\mu \mathrm{L}^{-1}$; valor onze vezes superior aos observados para sementes.

Essas amostras contendo concentrações variadas de DNA foram diluídas até valores mínimos exigidos para a amplificação de fragmentos microssatélites via PCR. Normalmente, se exige quantidade reduzida de DNA molde, que varia 
de 10 a 50ng, dependendo do volume final de reagentes necessários. Assim, a amostra da extração não necessita de valores elevados de DNA para satisfazer a análise. Porém, se as concentrações iniciais forem significativamente baixas, como à relativa ao tratamento $\mathrm{T} 1 \mathrm{em}$ sementes (Tabela 14), poucas reações poderão ser realizadas com essa amostra e, em casos de necessidade de maior número de amplificações, novas extrações de DNA são exigidas. Por outro lado, quantidades elevadas, como a observada em T11 (folhas) fornecem DNA para um grande número de reações, se for considerada uma necessidade média de 80ng por reação com microssatélites

Tabela 14. Quantificação (ng. $\mu \mathrm{L}^{-1}$ ) de DNA extraído a partir de sementes secas e folhas de plântulas de linhagens de milho

\begin{tabular}{|c|c|c|c|c|c|}
\hline \multirow{2}{*}{ Tratamento } & \multicolumn{2}{|c|}{ L1 - L2 (Ensaio A) } & \multirow{2}{*}{ Tratamento } & \multicolumn{2}{|c|}{ L3 - L4 (Ensaio B) } \\
\hline & Sementes & Folhas & & Sementes & Folhas \\
\hline T1 & 11 & 533 & T7 & 21 & 353 \\
\hline $\mathrm{T} 2$ & 17 & 356 & T8 & 22 & 342 \\
\hline T3 & 30 & 371 & T9 & 19 & 354 \\
\hline T4 & 22 & 484 & T10 & 27 & 367 \\
\hline T5 & 22 & 366 & T11 & 30 & 411 \\
\hline T6 & 23 & 418 & T12 & 16 & 339 \\
\hline
\end{tabular}

A quantidade de DNA por grama de semente de milho é comprovadamente reduzida, com predominância do DNA dos tecidos do embrião, seguido do endosperma e pericarpo (Zhang et al., 1996). Esse valor é atribuído à perda de DNA pelo tecido endospermático durante a fase de acúmulo de reservas nas sementes, ou seja, conforme o amido vai sendo formado ocorrem rupturas em organelas e o conteúdo celular é modificado, com redução expressiva da quantidade de ácidos nucléicos, culminando com a 
morte da célula e total preenchimento pelas reservas (McDonald et al., 1995). Uma vez que as sementes de milho são constituídas, em maior parte, pelo tecido endospermático, mesmo com elevado conteúdo de DNA no embrião a quantidade em relação à semente inteira é baixa, explicando os resultados apresentados no presente trabalho.

A presença de quantidade elevada de impurezas associadas ao DNA isolado a partir de sementes também contribui para a redução na concentração de DNA extraído. As sementes são estruturas de multiplicação vegetal, com tecido de reserva rico de carboidratos, lipídios e proteínas, responsável pelo suprimento do embrião durante o processo de germinação (Carvalho \& Nakagawa, 2000). Essas substâncias de reserva dificultam o isolamento do DNA, exigindo maior número de lavagens com solvente orgânico (clorofórmioálcool isolamílico), durante o protocolo de extração. Esse procedimento implica, também, em redução na quantidade total de DNA isolado, pois parte dessas moléculas não se separam de outros compostos orgânicos e são consequentemente descartadas.

Na Figura 7 é observada a menor intensidade de bandas provenientes de amostras de sementes em comparação às de folhas de plântulas verificadas na Figura 8. A elevada concentração de DNA obtido a partir das primeiras folhas verdadeiras de plântulas era esperada, pois tecidos tenros, característicos de partes em intenso crescimento e desenvolvimento, encontram-se em alta atividade metabólica, o que implica em elevada multiplicação celular e de ácidos nucléicos. Ferreira \& Grattapaglia (1998) recomendam que o tecido a ser utilizado na extração de DNA deve ser de preferência recém-colhido e se possível retirado na fase ativa de crescimento das plantas. Assim, o tecido de plântulas preenche inteiramente esses requisitos.

Com a finalidade de identificar os fatores que poderiam interferir na técnica RAPD, Boiteus et al. (1999) testaram diferentes tecidos de cenoura, como fonte de DNA molde, e observaram que a maior quantidade de DNA foi isolada a partir da inflorescência, seguida pela semente e folhas recém- 
colhidas. As diferenças na concentração de DNA entre os tecidos podem ser explicadas por variações específicas de cada tecido, como o número e tamanho das células, a taxa de divisão celular e quantidade de DNA extracelular ou mesmo por diferenças na composição química e estrutural desses tecidos.

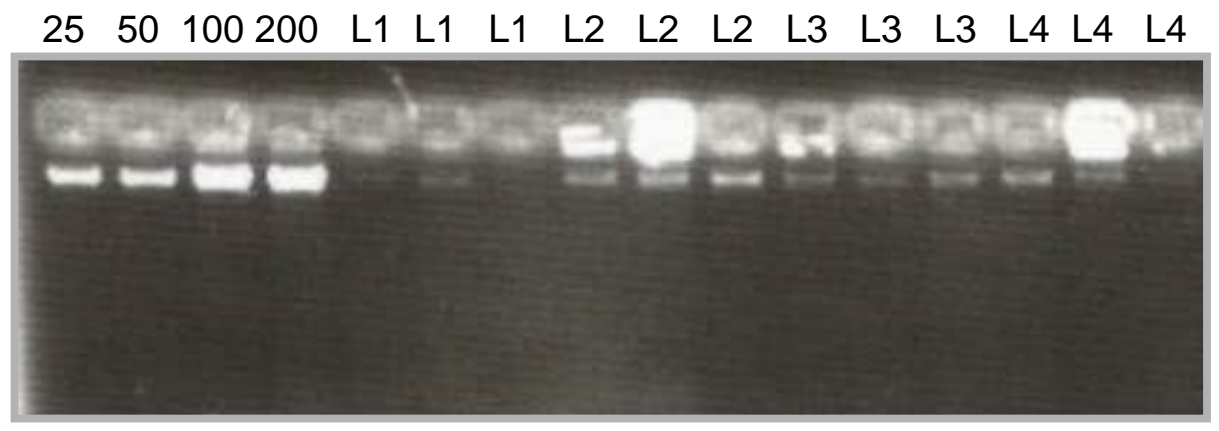

Figura 7 - Quantificação de DNA extraído de sementes de linhagens de milho, em gel de agarose (1\%). Nas quatro primeiras canaletas encontram-se os fragmentos do fago $\gamma$ com valores conhecidos, expressos em $n g . \mu \mathrm{L}^{-1}$. Nas demais canaletas são observadas as amostras das linhagens L1, L2, L3 e L4, em três repetições.

50100200400 L1 L1 L1 L2 L2 L2 L3 $\quad$ L3 $\quad$ L3 $\quad$ L4 $\quad$ L4 $\quad$ L4

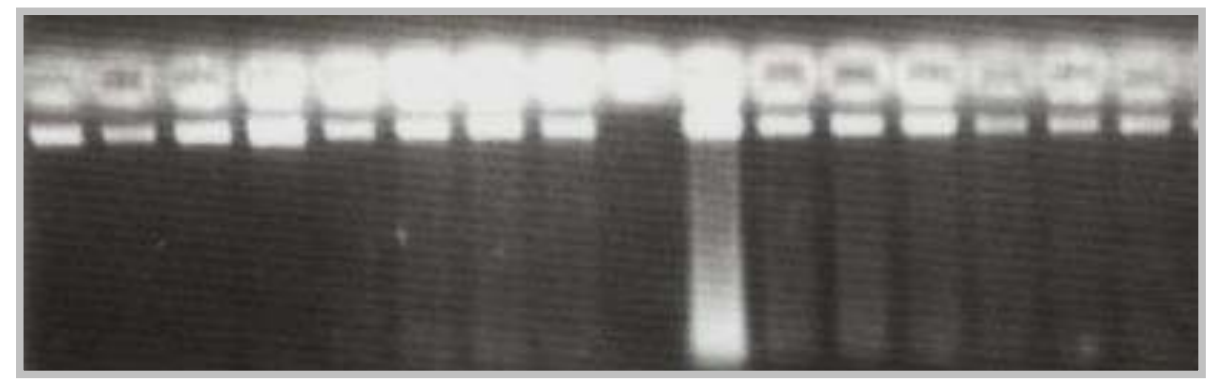

Figura 8 - Quantificação de DNA extraído de folhas de plântulas de milho, em gel de agarose (1\%). Nas quatro primeiras canaletas encontram-se os fragmentos do fago $\gamma$ com valores conhecidos, expressos em ng. $\mu \mathrm{L}^{-1}$. Nas demais canaletas são observadas as amostras das linhagens L1, L2, L3 e L4, em três repetições 
McDonald et al. (1994) demostraram que a qualidade e a quantidade do DNA extraído de sementes secas de milho, algodão, soja, trigo e trevo vermelho foram satisfatórias para o sucesso de análises moleculares do tipo RAPD. Para as sementes de amendoim, o protocolo de extração deixou a desejar no quesito qualidade, em função do alto teor de óleo encontrado nessas sementes, o que sugere a necessidade de maior número de lavagens para a purificação do DNA. Schuster et al. (2004) testaram um protocolo para a extração de DNA de sementes de soja sem a adição das enzimas proteinase $K$ e RNAse A, utilizadas por McDonald et al. (1994), e observaram que os resultados foram inferiores tanto para a qualidade como a quantidade de DNA extraído. No presente trabalho não foi utilizada a proteinase $K$, porque a quantidade de proteínas armazenadas em sementes de milho é significativamente inferior à encontrada em sementes de soja.

Em função da maior quantidade de DNA obtido a partir de tecidos de plântulas ou plantas, essas partes são usadas na maioria dos protocolos para extração de DNA vegetal. Porém, para laboratórios de análise de sementes, o período necessário para o desenvolvimento dessas estruturas é indesejável e pode comprometer o uso de técnicas moleculares em análises de rotina (McDonald et al., 1994). Neste contexto, técnicas moleculares como as baseadas em microssatélites, que exigem quantidades mínimas de DNA para a amplificação via PCR (Wu et al., 1994; Ferreira \& Grattapaglia, 1998), podem utilizar sementes como material fornecedor de DNA, mesmo que a quantidade extraída seja reduzida, desde que de qualidade satisfatória.

Os resultados observados na Figura 9 demonstram que as amostras obtidas a partir de sementes $(A)$ apresentaram padrões de bandas que sugerem que o DNA encontrava-se em melhor estado de conservação em comparação ao DNA total extraído de tecidos foliares (B). Essas amostras foram armazenadas por aproximadamente um ano em "freezer" a $-20^{\circ} \mathrm{C}$. Na literatura, não são encontrados trabalhos envolvendo armazenamento de amostras de DNA não liofilizadas. Talvez a semente, por ser uma estrutura de multiplicação 
vegetal, ofereça maior proteção ao material genético contido no interior de suas células, uma vez que uma de suas funções é garantir a perpetuação da espécie, mesmo em condições de estresse. Assim, o baixo conteúdo de água, a inativação enzimática e o metabolismo desacelerado, resultam na menor presença de enzimas oxidativas que aceleram a degradação do DNA.

Portanto, tanto o tecido foliar como a semente podem ser adequados para o isolamento de DNA; porém, para análise de rotina o uso de sementes é mais interessante pela economia de tempo e espaço na obtenção dos resultados, sendo portanto o mais recomendado.

$122 \quad 3 \quad 4 \quad 5 \quad 6 \quad 7 \quad 8 \quad 9101112131415161718192021222324$

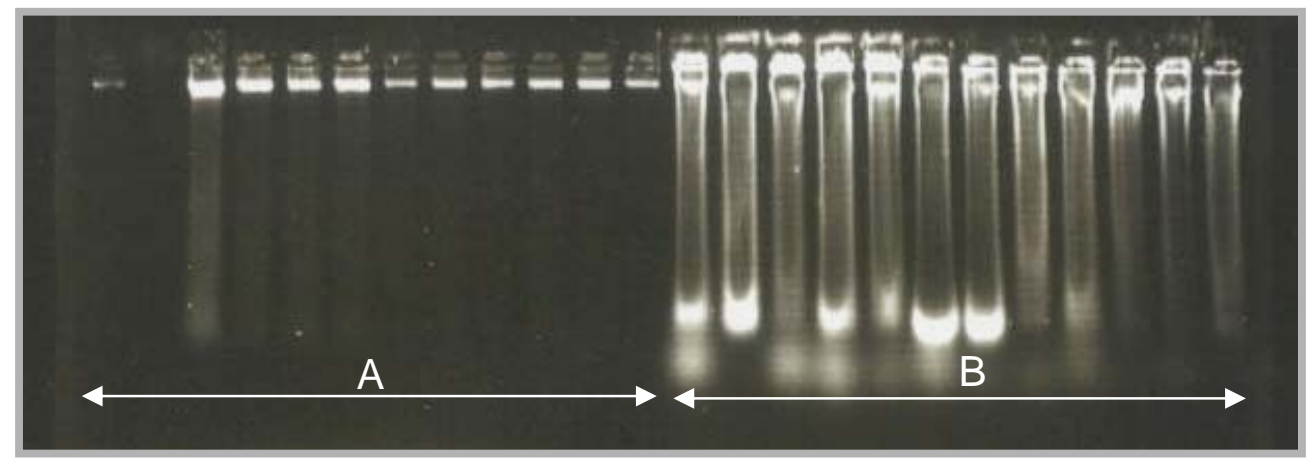

Figura 9 - Padrões de bandas de DNA total isolado a partir de amostras de sementes (A) e de folhas de plântulas (B), após um ano de armazenamento em freezer a $-20^{\circ} \mathrm{C}$

\subsubsection{Amplificação via PCR de locos miocrossatélites para avaliação de pureza varietal em lotes de sementes}

O exame da Figura 10 A permite observar que a banda característica da linhagem contaminante não foi convenientemente amplificada nos tratamentos contendo misturas. Isto ocorreu, provavelmente, pela concentração insuficiente (30ng) de DNA molde para ser amplificado através da PCR, ou seja, o DNA da linhagem considerada como pura predominou como molde para a ação da 
enzima Taq DNA polimerase. Após o aumento na concentração do DNA molde utilizado na reação, verificou-se que os fragmentos característicos das linhagens contaminantes foram, também, detectados (Figura $10 \mathrm{~B}$ ). Por outro lado, nas misturas com L3 e L4, não foi possível identificar, em gel de agarose (Figura $11 \mathrm{~A}$ ), a presença do fragmento característico de L4 (linhagem contaminante), mesmo com o uso de concentrações elevadas de DNA molde (80ng) na reação de amplificação, com exceção ao tratamento contendo 100\% dessa linhagem (T12). Assim optou-se pelo uso do gel de poliacrilamida (Figura 11 B) para a resolução das amostras contendo essas linhagens, que foi altamente satisfatório na separação dos fragmentos de interesse.

O uso de poliacrilamida ou mesmo de agarose de alta resolução é recomendado por Ferreira \& Grattapaglia (1998) para a resolução de fragmentos microssatélites. Esses autores afirmam que um gel com matriz mais concentrada é exigido para a separação de segmentos que diferem por poucos pares de bases, dependendo do número de nucleotídeos do elemento repetido no microssatélite. Portanto, resolução de um fragmento que comprovadamente estava presente na amostra (com as misturas das linhagens L3 e L4), no gel de agarose, pode ser resultado da não separação das bandas características de ambas as linhagens, que, provavelmente possuem número próximo de nucleotídeos nesses fragmentos amplificados. 


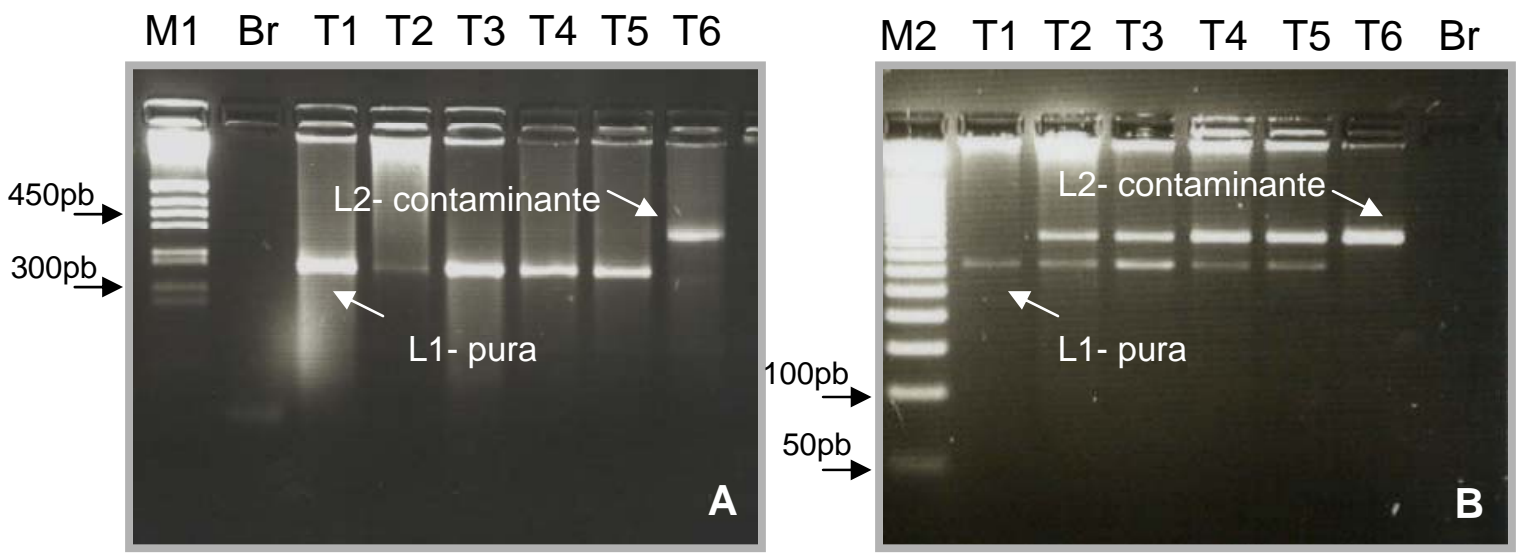

Figura 10 - Padrões de amplificação do microssatélite BNLG 125 obtido a partir de $A$ reação contendo 30ng de concentração de DNA molde e B- 80ng de concentração de DNA molde. Onde: Br corresponde a amostra testemunha ou branco, T1 corresponde a proporção 100\%L1+0\%L2, T2 $99 \% \mathrm{~L} 1+1 \% \mathrm{~L} 2, \quad \mathrm{~T} 3-98 \mathrm{~L} 1 \%+2 \%$ L2, T4 - 95\%L1+5\%L2, T5 90\%L1+10\%L2, T6 - 0\%L1+100\%L2 e M1 corresponde ao marcador com $1 \mathrm{~Kb}$ ladder de peso molecular(Promega $1 \mathrm{~Kb}$ Ladder) e M2 marcador com 50pb de peso molecular (Promega)

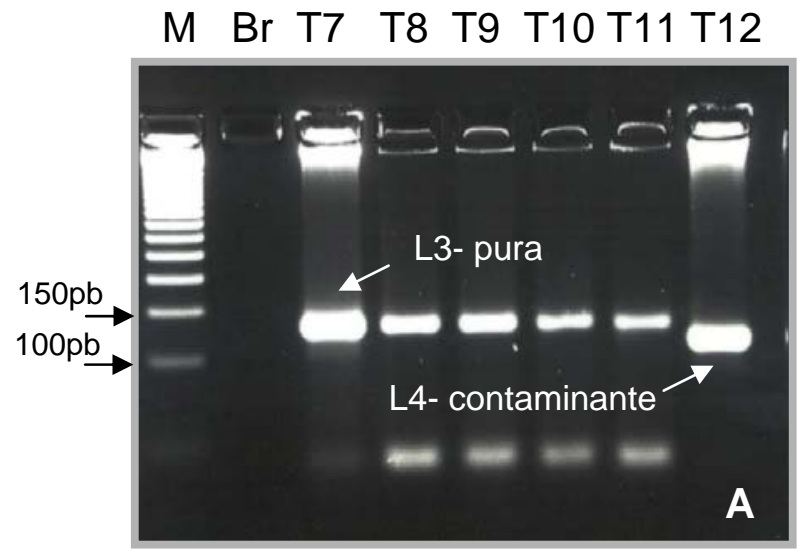

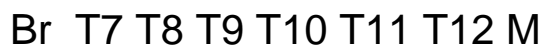

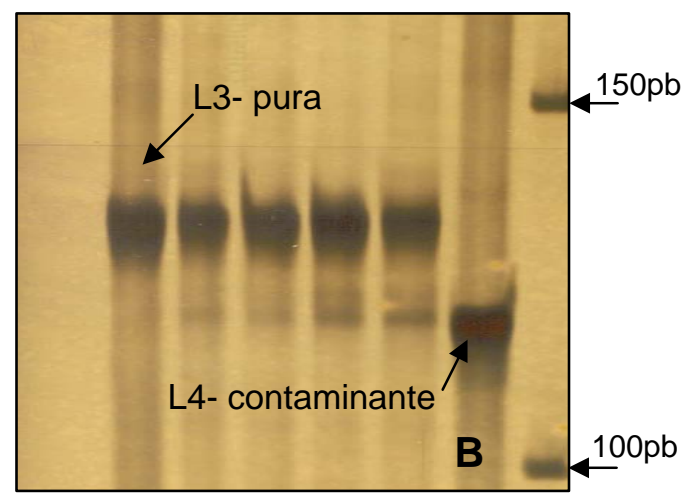

Figura 11 - Padrões de amplificação do microssatélite BNLG 240 obtido a partir de $A$ reação resolvida em gel de agarose $(3,5 \%)$ e B- reação resolvida em gel de poliacrilamida (6\%). Onde: $\mathrm{Br}$ corresponde a amostra testemunha ou branco, T7 corresponde a proporção 100\%L3+0\%L4, T8 - 99\%L3+1\%L4, T9 - 98\%L3+2\%L4, T10 - 95\%L3+5\%L4, T11 - 90\%L3+10\%L4, T12 0\%L3+100\%L4 e M corresponde ao marcador com 50pb de peso molecular (Promega) 
Os padrões de amplificação do microssatélite BNLG 125, obtidos a partir de amostras de misturas entre as linhagens L1 e L2 (ensaio A) podem ser observados nas figuras 12, 13, 14 e 15. Verificou-se que não houve diferença nos padrões entre as amostras amplificadas a partir de DNA extraído de sementes e de folhas de plântulas. Porém, o nível de resolução dos fragmentos foi diferente entre essas amostras, pois aqueles amplificados a partir de DNA de folhas de plântulas apresentaram melhor definição em relação aos amplificados a partir de sementes. Isso pode ser resultante da menor quantidade de impurezas presentes no DNA extraído dos tecidos foliares, que implicam em maior disponibilidade de DNA molde a ser amplificado.

A matriz utilizada na resolução das amostras interferiu na qualidade das bandas amplificadas, sendo que, os padrões observados em gel de agarose $(3,5 \%)$ foram menos nítidos que os resolvidos em gel de poliacrilamida $(6 \%)$. Esse resultado era esperado, pois a poliacrilamida permite a separação de fragmentos com pequena diferença no número de bases.

A respeito dos tratamentos contendo os diferentes níveis de misturas de sementes, verificou-se que a presença da linhagem contaminante foi detectada na amostra com até 1\% (T2) de mistura. Esta constatação é suficiente para impedir a utilização do lote em avaliação, uma vez que não é tolerada a presença de sementes de outros genótipos em sementes básicas de milho.

Nas amostras resolvidas em gel de poliacrilamida (Figuras 14 e 15) foi possível observar variação na intensidade de bandas, devido à elevação da concentração de DNA da linhagem contaminante. Assim, para o tratamento T5, com $10 \%$ de mistura, a banda característica da linhagem contaminante L2 foi mais intensa que a observada no tratamento $\mathrm{T} 2$, contendo $1 \%$ de mistura.

Em gel de agarose (Figuras 12 e 13) não foi possível observar variação na intensidade de bandas; dessa maneira, tanto a presença de $1 \%$ de contaminação como de $10 \%$ originaram padrão de bandas semelhantes. A resolução em gel de agarose também não permitiu a observação de bandas características da linhagem contaminante L4, nos tratamentos (T8, T9, T10 e 
T11) constituídos por misturas varietais (Figura 9 A). Isto inviabiliza o uso dessa matriz para análise com o microssatélite BNLG 240, em amostras com misturas de L3 e L4 (ensaio B). Portanto, os padrões de amplificação do microssatélite BNLG 240, obtidos a partir de amostras do ensaio B foram observados apenas em gel de poliacrilamida (6\%) com resultados apresentados na Figuras 16 e 17. Não houve diferença nos padrões entre amostras amplificadas a partir de DNA extraído de um "pool" de sementes ou de folhas de plântulas.

A detecção de níveis mínimos de contaminação é primordial para a implementação de métodos destinados à avaliação de pureza varietal de sementes. Se esses níveis de detecção puderem se associar ao uso de amostra com várias sementes ("pool"), que representem praticamente uma repetição dentro da análise a ser realizada, tanto a eficiência na obtenção de resultados pode ser elevada, como o custo por análise pode ser reduzido, melhorando a agilidade nos programas de controle de qualidade. Até o presente momento, a maioria das análises moleculares, na área de sementes, são realizadas em amostras com sementes individuais, que implicam em maior gasto de tempo e de reagentes.

No presente experimento foi confirmada a possibilidade de uso de amostras contendo até 100 sementes (Figuras 12 a 17). Assim, a técnica de microssatélites utilizando amostra com DNA extraído de até 100 sementes pode ser recomendada com segurança em análises de determinação de pureza varietal em lotes de sementes de linhagens de milho, através de microssatélites, desde que os genótipos analisados encontrem-se com alto nível de homozigose. Para sementes híbridas, essa metodologia pode não ser eficaz para detectar a presença de sementes de um dos parentais, remanescentes no lote. O microssatélite é um marcador com caráter codominante e não permite verificar se a banda presente é decorrente apenas do híbrido ou se pode ser resultante da contaminação com um dos parentais. Por outro lado, a detecção da presença de sementes de outros cultivares pode ser feita com eficiência. 


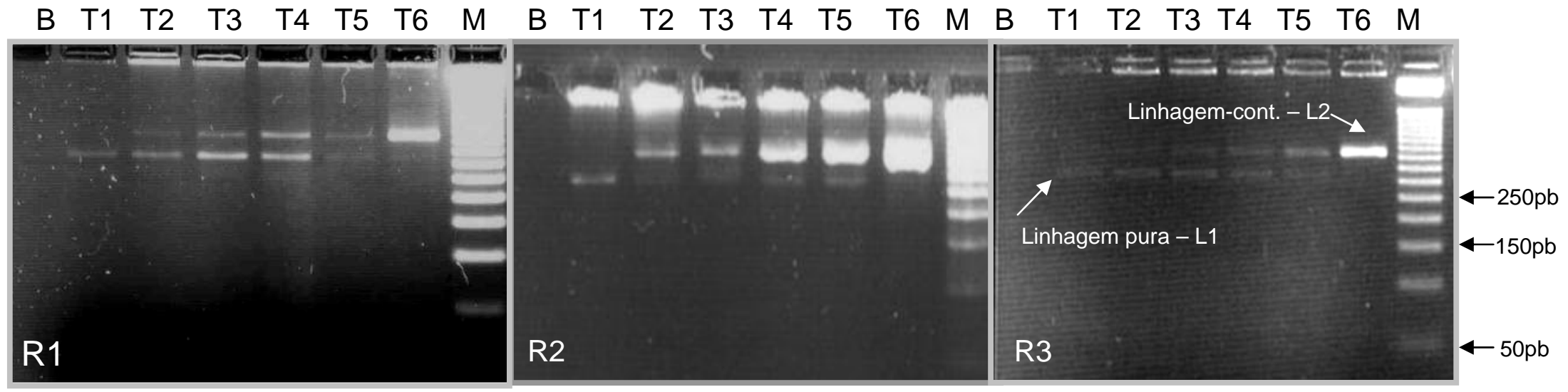

Figura 12 - Padrões de amplificação do microssatélite BNLG 125, resolvidos em gel de agarose, a partir de DNA extraído de amostras de sementes de linhagens de milho L1 e L2 (ensaio A), em três repetições (R1, R2 e R3), onde B corresponde à amostra testemunha ou branco, T1 corresponde à proporção 100\%L1+ 0\%L2, T2 - 99\%L1+1\%L2, T3 - 98\%L1+2\%L2, T4 - 95\%L1+5\%L2, T5 - 90\%L1+10\%L2, T6 0\%L1+100\%L2 e M corresponde ao marcador com peso 50pb de peso molecular (Promega) 


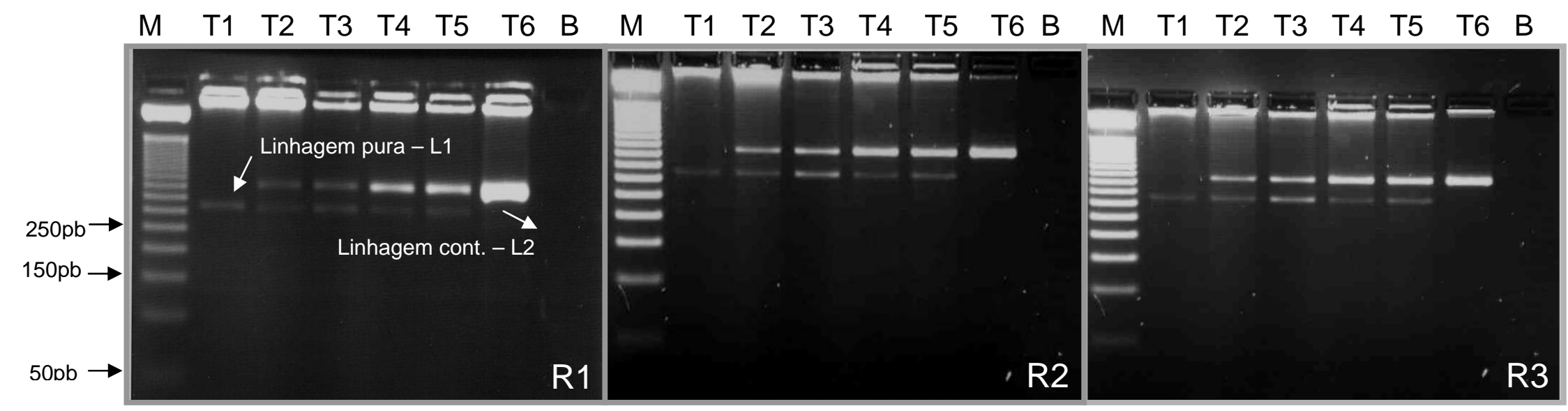

Figura 13 - Padrões de amplificação do microssatélite BNLG 125, resolvidos em gel de agarose, a partir de DNA extraído de amostras de folhas de plântulas de linhagens de milho L1 e L2 (ensaio A), em três repetições (R1, R2 e R3), onde B corresponde à amostra testemunha ou branco, T1 corresponde a proporção 100\%L1+ 0\%L2, T2 - 99\%L1+1\%L2, T3 - 98\%L1+2\%L2, T4 - 95\%L1+5\%L2, T5 90\%L1+10\%L2, T6 - 0\%L1+100\%L2 e M corresponde ao marcador com 50pb de peso molecular (Promega) 


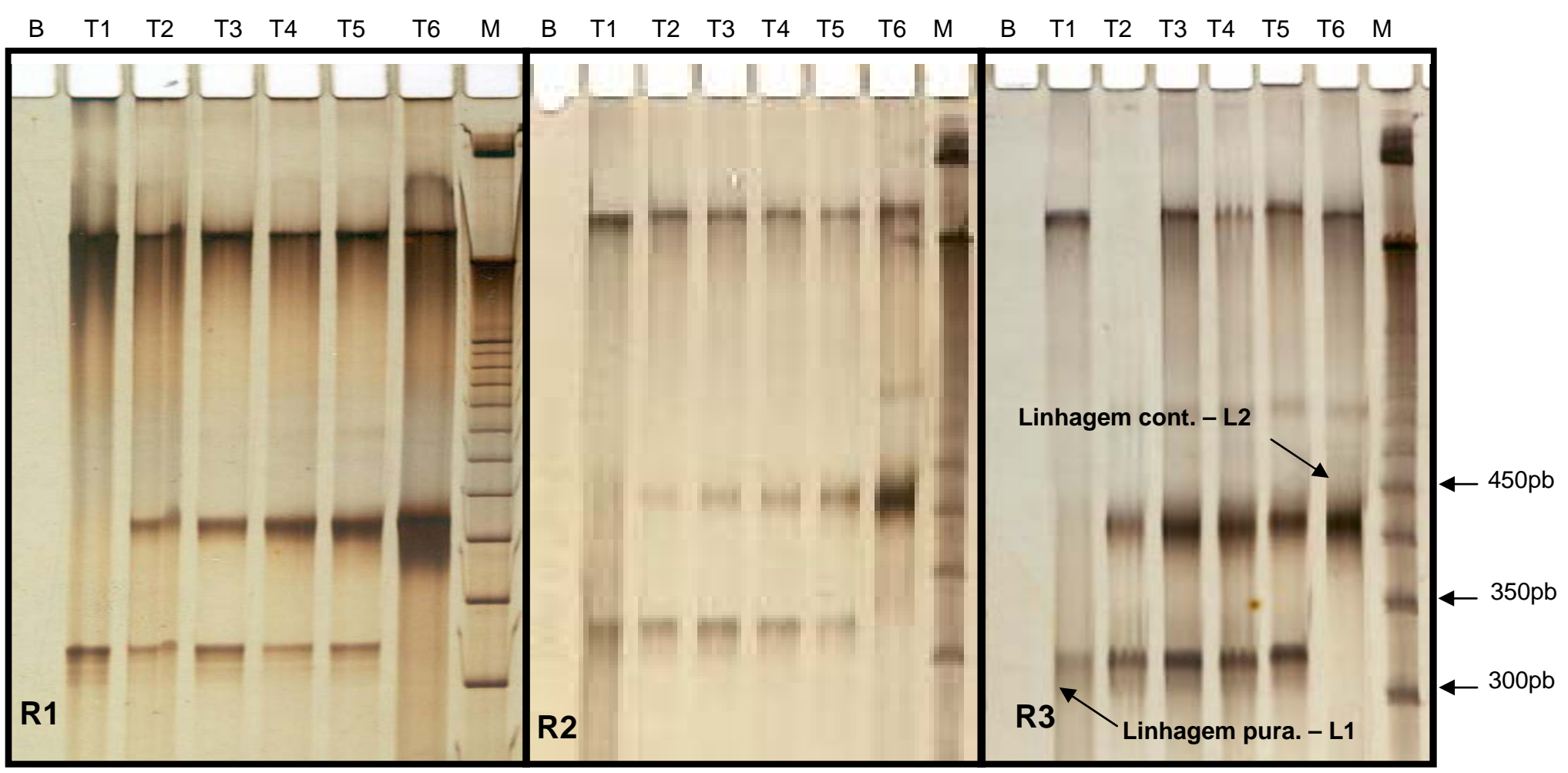

Figura 14 - Padrões de amplificação do microssatélite BNLG 125, resolvidos em gel de poliacrilamida, a partir de DNA extraído de amostras de sementes de linhagens de milho L1 e L2 (ensaio A), em três repetições (R1, R2 e R3), onde B corresponde à amostra testemunha ou branco, T1 corresponde à proporção 100\%L1+ 0\%L2, T2 - 99\%L1+1\%L2, T3 - 98\%L1+2\%L2, T4 - 95\%L1+5\%L2, T5 - 90\%L1+10\%L2, T6 $-0 \% \mathrm{~L} 1+100 \% \mathrm{~L} 2$ e $\mathrm{M}$ corresponde ao marcador de 50pb de peso molecular (Promega) 


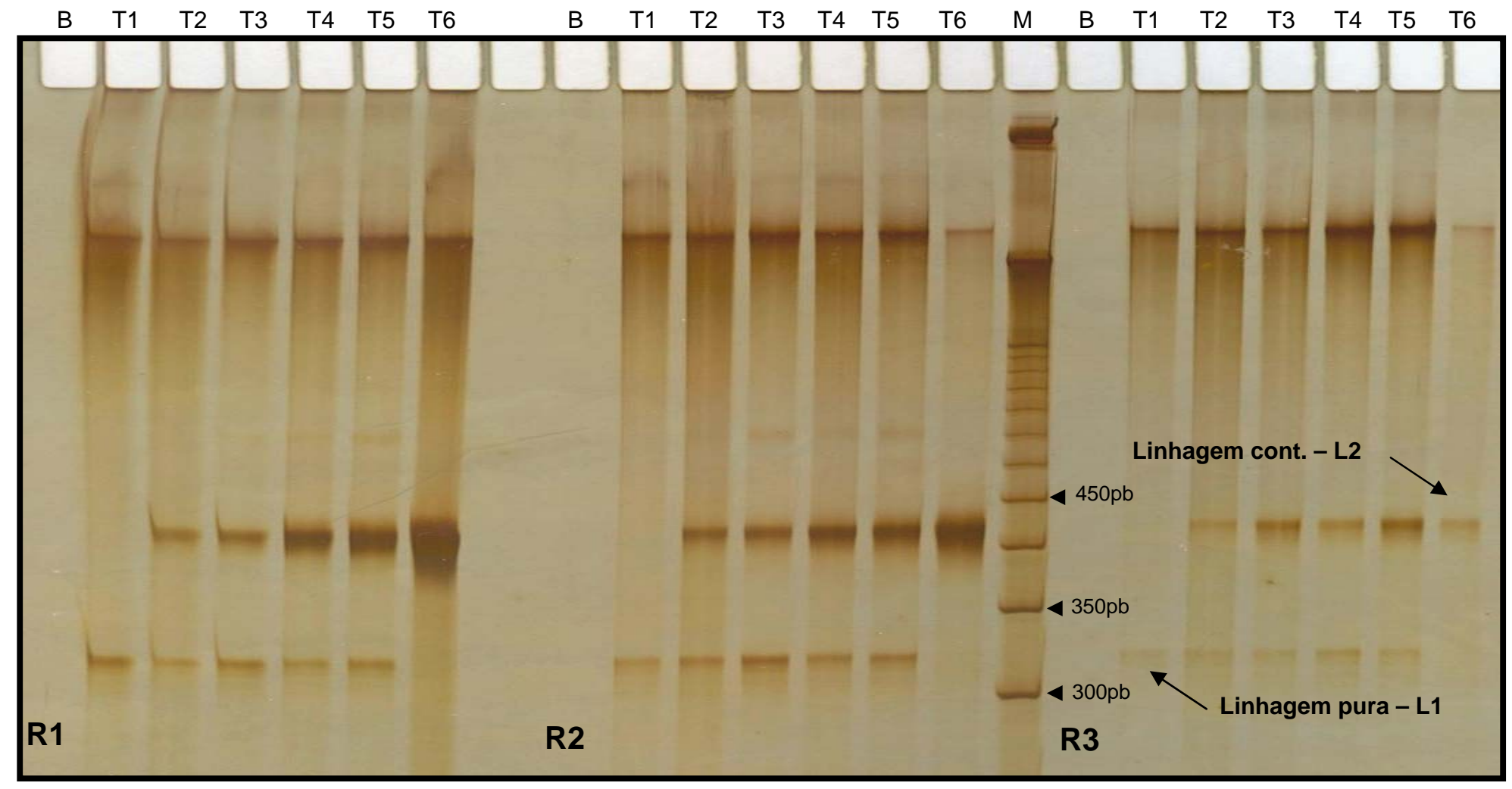

Figura 15 - Padrões de amplificação do microssatélite BNLG 125, resolvidos em gel de poliacrilamida, a partir de DNA extraído de amostras de folhas de plântulas de linhagens de milho L1 e L2 (ensaio A), em três repetições (R1, R2 e R3), onde $B$ corresponde à amostra testemunha ou branco, T1 corresponde à proporção 100\%L1+ 0\%L2, T2 - 99\%L1+1\%L2, T3 - 98\%L1+2\%L2, T4 - 95\%L1+5\%L2, T5 90\%L1+10\%L2, T6 - 0\%L1+100\%L2 e M corresponde ao marcador com 50pb de peso molecular (Promega) 


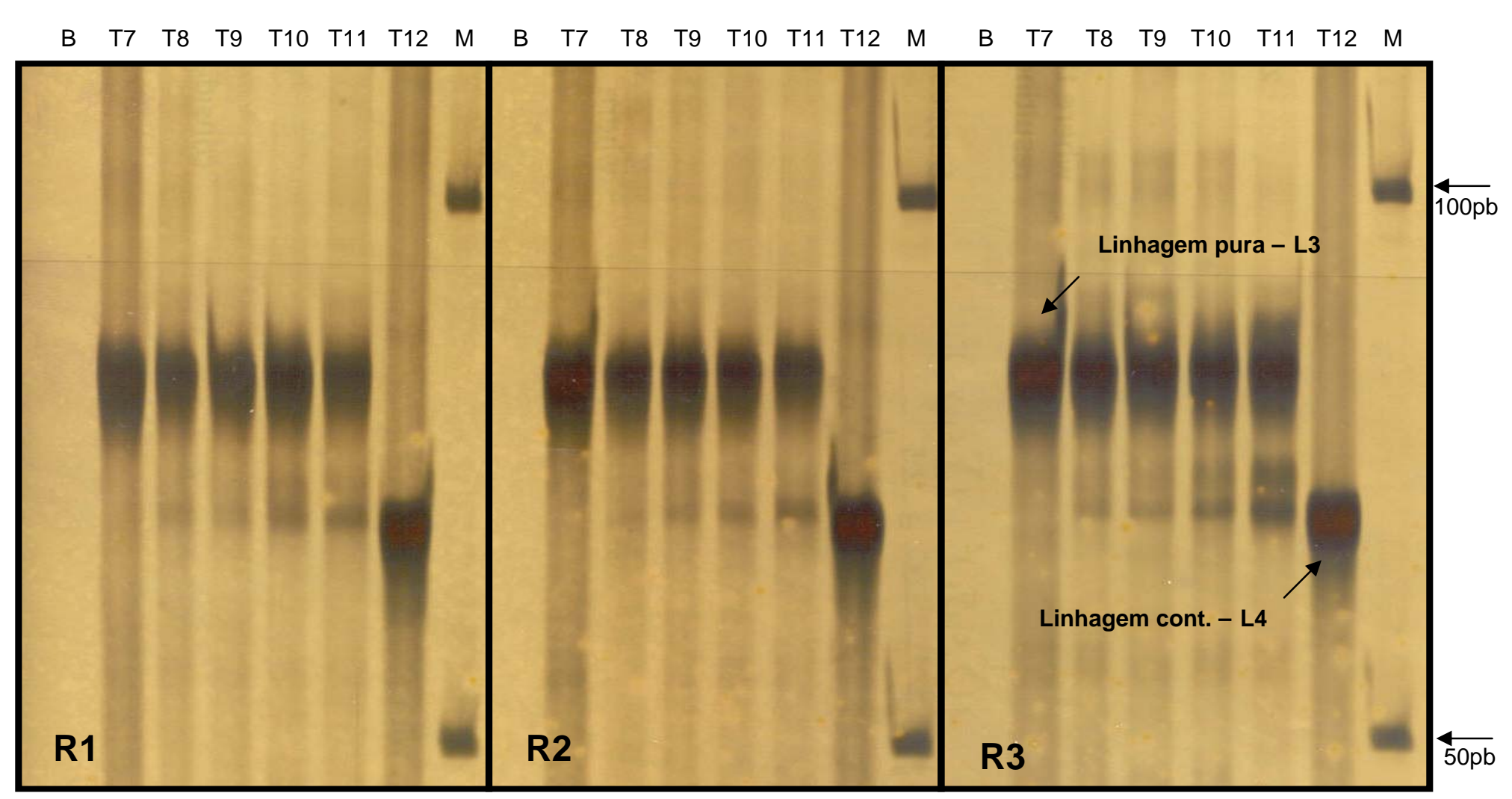

Figura 16 - Padrões de amplificação do microssatélite BNLG 240, resolvidos em gel de poliacrilamida, a partir de DNA extraído de amostras de sementes de linhagens de milho L3 e L4 (ensaio B), em três repetições (R1, R2 e R3), onde B corresponde à amostra testemunha ou branco, T7 corresponde a proporção 100\%L3+0\%L4, T8 - 99\%L3+1\%L4, T9 - 98\%L3+2\%L4, T10 - 95\%L3+5\%L4, T11 - 90\%L3+10\%L4, T12 - 0\%L3+100\%L4 e M corresponde ao marcador com 50pb de peso molecular (Promega) 


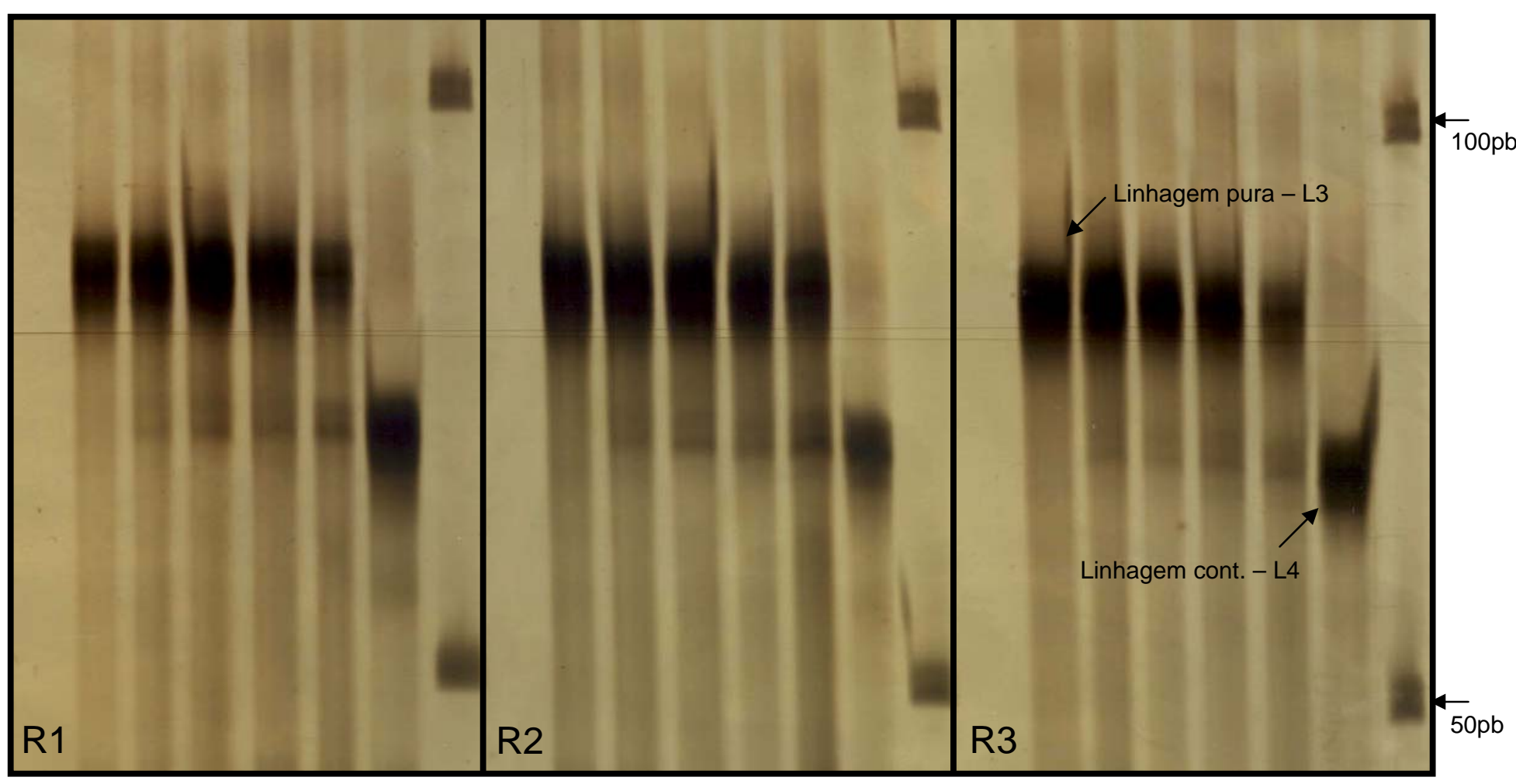

Figura 17 - Padrões de amplificação do microssatélite BNLG 240, resolvidos em gel de poliacrilamida, a partir de DNA extraído de amostras de folhas de plântulas de linhagens de milho L3 e L4 (ensaio B), em três repetições (R1, R2 e R3), onde $B$ corresponde à amostra testemunha ou branco, $T 7$ corresponde à proporção 100\%L3+0\%L4, T8 - 99\%L3+1\%L4, T9 - 98\%L3+2\%L4, T10 - 95\%L3+5\%L4, T11 90\% $3+10 \% \mathrm{~L} 4, \mathrm{~T} 12$ - 0\% $33+100 \% \mathrm{~L} 4$ e $\mathrm{M}$ corresponde ao marcador com 50pb de peso molecular (Promega) 
Salgado (2001) verificou que o método microssatéite foi eficiente para determinar a pureza genética em lotes de sementes híbridas de milho; porém as avaliações foram realizadas, individualmente, ou seja, cada semente foi considerada uma amostra. Entretanto, o trabalho realizado por Schuster et al. (2004), utilizando amostras com misturas de DNA proveniente de várias sementes de soja, permitiu afirmar que métodos de análise em "bulk" de amostras de DNA de sementes atípicas, através de microssatélites, fornecem resultados com mesma precisão de análise individual e com custo inferior. Essa diferença na opção por amostra com várias sementes ou apenas com uma semente resulta do caráter co-dominante do marcador microssatélite.

Outra vantagem significativa na utilização de amostra com várias sementes associada à técnica de microssatélites é a possibilidade de uso de vários iniciadores em uma mesma reação de amplificação (multiplex PCR), tornando viável a detecção de mais de um genótipo contaminante nessa amostra. Esse tipo de reação é interessante tanto pela economia de tempo como de reagentes. Em uma mesma reação podem ser obtidas várias informações a respeito dos possíveis contaminantes de uma amostra. Na prática, as empresas produtoras de sementes poderiam obter locos microssatélites polimórficos entre os vários genótipos que produzem e, seria possível trabalhar com combinações desses iniciadores para determinar a pureza varietal de lotes de interesse.

\subsubsection{Sensibilidade dos marcadores microssatélites para avaliar pureza varietal através da simulação de contaminação em amostras de DNA}

Através de simulações com misturas de DNA entre as linhagens foi possível detectar, com clareza e repetibilidade, concentrações de até 0,1\% (T5 e T17) de contaminantes, que correspondem à proporção de uma semente 
contaminante em amostras de 1000 sementes (Figuras 18, 19, 20 e 21). Esse resultado é significativamente satisfatório, pois confere maior rigor à análise, uma vez que quanto maior a sensibilidade em detectar níveis mínimos, menor a probabilidade de erro no diagnóstico. O risco de aceitar lotes impuros ou rejeitar indevidamente lotes puros é elevado, assim, o uso de técnicas que reduzam ao máximo a possibilidade de ocorrência de erros, em função da alta sensibilidade de detecção, tornam a análise mais confiável.

Nas Regras para Análise de Sementes o tamanho da amostra média de sementes de milho a ser enviada ao laboratório para verificação de espécies e cultivares é de, no mínimo, 1000 gramas (Brasil, 1992). Dessa amostra são avaliadas cerca de 400 sementes retiradas da porção "semente fisicamente pura" com a finalidade de estimar a presença de outros cultivares. O exame deve ser feito em repetições de no máximo 100 sementes. Porém, atualmente se questiona o tamanho dessa amostra e o número de sementes a serem avaliadas, principalmente para a detecção de organismos geneticamente modificados. O uso de subamostras com mais de 100 sementes pode reduzir o risco de erros na determinação de impurezas, mas implica em maior custo por análise, se as sementes forem avaliadas individualmente, como é recomendado para métodos izoenzimáticos pela ISTA (1996) e AOSA (1991). Atualmente, já existem testes para detecção de contaminação em grãos, que utilizam até mil unidades, com sensibilidade de 0,1\% (método da proteína CP4 EPSPS para soja Roundup ${ }^{\circledR}$ Ready).

A simulação de contaminação entre linhagens através de misturas de DNA permitiu verificar que os microssatélites além de altamente eficientes em detectar níveis elevados de contaminação, apresentam sensibilidade de detecção de contaminações de até 0,1\% (Figuras 18 a 21). Portanto, servem de suporte para a implementação da proposta de aumento no número de sementes para avaliação de pureza varietal.

$\mathrm{Na}$ literatura podem ser encontrados trabalhos utilizando diluições de DNA simulando misturas em diversas concentrações, mas geralmente a finalidade é 
determinar a interferência de DNA contaminante nas reações de amplificação, principalmente, para RAPD, que é altamente influenciado por alterações nos componentes da PCR. Zhang et al. (1996) simulou contaminações em amostra do cultivar de soja Thorne, com DNA extraído de uma outro cultivar (Vickery), com níveis crescentes de mistura $(10,20,30, \ldots, 90$ e 100\%). Esses autores constataram que a intensidade da banda característica do genótipo Thorne foi reduzida à medida que a contaminação com a variedade Vickery aumentava na amostra. Porém, foi possível detectar a presença de Thorne, mesmo quando as concentrações do contaminante (Vickery) atingiram 90\%.

Staub et al. (1996), trabalhando com simulação de contaminação entre duas linhagens de pepino (PI432860 e GY-14a), observaram amplificação de fragmentos através de RAPD, em contaminações superiores a 5\% ( $\geq 20: 1)$, enquanto a banda contaminante não foi observada em níveis inferiores a $2 \%$ (50:1). A técnica de RAPD é baseada na amplificação ao acaso; assim, o DNA molde presente em maior quantidade, muitas vezes prevalece na PCR. Por outro lado, os microssatélites utilizam iniciadores complementares a regiões genômicas específicas, ficando menos sujeitos à não amplificação, mesmo em baixas concentrações de DNA molde.

Nesse contexto, o uso de amostras contendo várias sementes além de reduzir os custos de análise, permite a avaliação de vários lotes simultaneamente, aproveitando com maior eficiência o tempo de trabalho disponível. Com relação ao tempo, a extração de DNA a partir de sementes também reduz o período para a obtenção de resultados e contribui para a economia de espaço nos laboratórios de análise de sementes. 


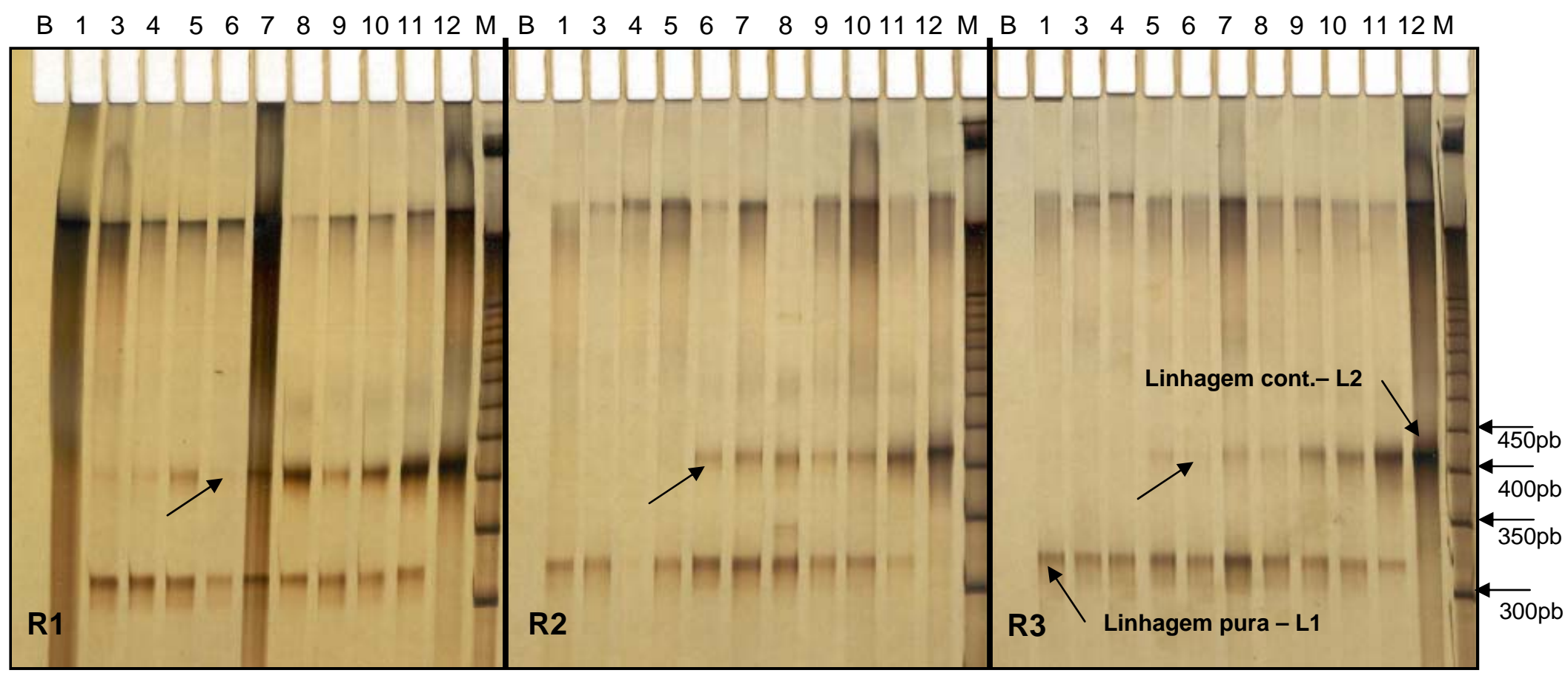

Figura 18 - Padrões de amplificação do microssatélite $B N L G$ 125, resolvidos em gel de poliacrilamida em três repetições (R1, R2 e R3), obtidos de amostras de DNA de sementes das linhagens de milho L1 e L2 (ensaio A), diluídas em diferentes proporções, onde B corresponde à amostra testemunha ou branco, 1(T1) - corresponde à proporção 100\%L1+0\%L2, 3(T3) - 99,987\%L1+0,013\%L2, 4(T4) - 99,98\%L1+0,02\%L2, 5(T5) 99,96\%L1+0,04\%L2, 6(T6) - 99,9\%L1+0,1\%L2, 7(T7) - 99,8\%L1+0,2\%L2, 8(T8)- 99\%L1+1\%L2, 9(T9) 98\%L1+2\%L2, 10(T10) - 95\%L1+5\%L2, 11(T11) - 90\%L1+10\%L2, 12(T12) - 0\%L1+100\%L2 e M corresponde ao marcador com 50pb de peso molecular (Promega) 
$\begin{array}{lllllllllllllllllllllllllllllllllllllllllllllllll}\mathrm{B} & 1 & 2 & 3 & 4 & 5 & 6 & 7 & 8 & 9 & 10 & 11 & 12 & \mathrm{M} & \mathrm{B} & 1 & 2 & 3 & 4 & 5 & 6 & 7 & 8 & 9 & 10 & 11 & 12 & \mathrm{M} & \mathrm{B} & 1 & 2 & 3 & 4 & 5 & 6 & 7 & 8 & 9 & 10 & 11 & 12 & \mathrm{M}\end{array}$

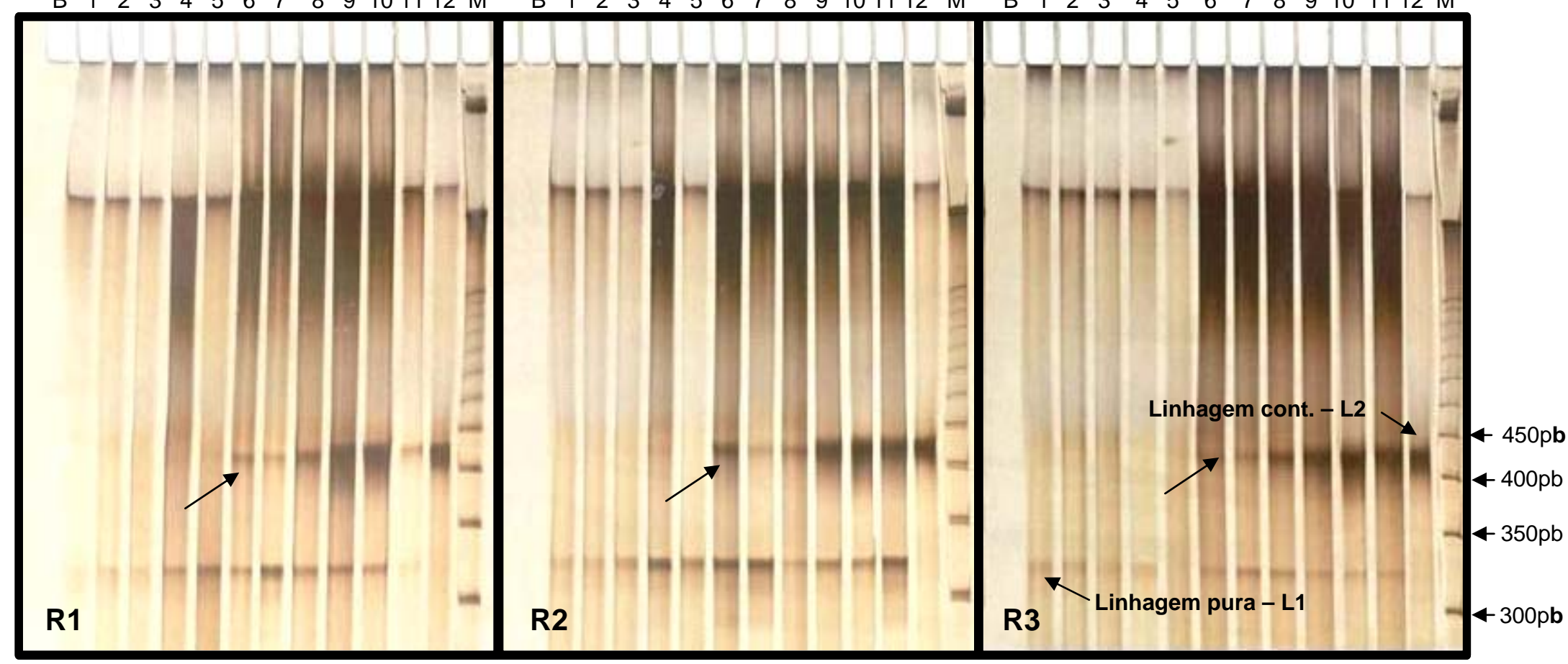

Figura 19 - Padrões de amplificação do microssatélite BNLG 125, resolvidos em gel de poliacrilamida em três repetições (R1, R2 e R3), obtidos de amostras de DNA de folhas de plântulas das linhagens de milho L1 e L2 (ensaio A), diluídas em diferentes proporções, onde B corresponde à amostra testemunha ou branco, 1(T1) - corresponde à proporção 100\%L1+0\%L2, 2(T2) - 99,99\%L1+0,01\%L2, 3(T3) - 99,987\%L1+0,013\%L2, 4(T4) 99,98\%L1+0,02\%L2, 5(T5) - 99,96\%L1+0,04\%L2, 6(T6) - 99,9\%L1+0,1\%L2, 7(T7) - 99,8\%L1+0,2\%L2, 8(T8)- 99\%L1+1\%L2, 9(T9) - 98\%L1+2\%L2, 10(T10) - 95\%L1+5\%L2, 11(T11) - 90\%L1+10\%L2, 12(T12) 0\%L1+100\%L2 e M corresponde ao marcador com 50pb peso molecular (Promega) 


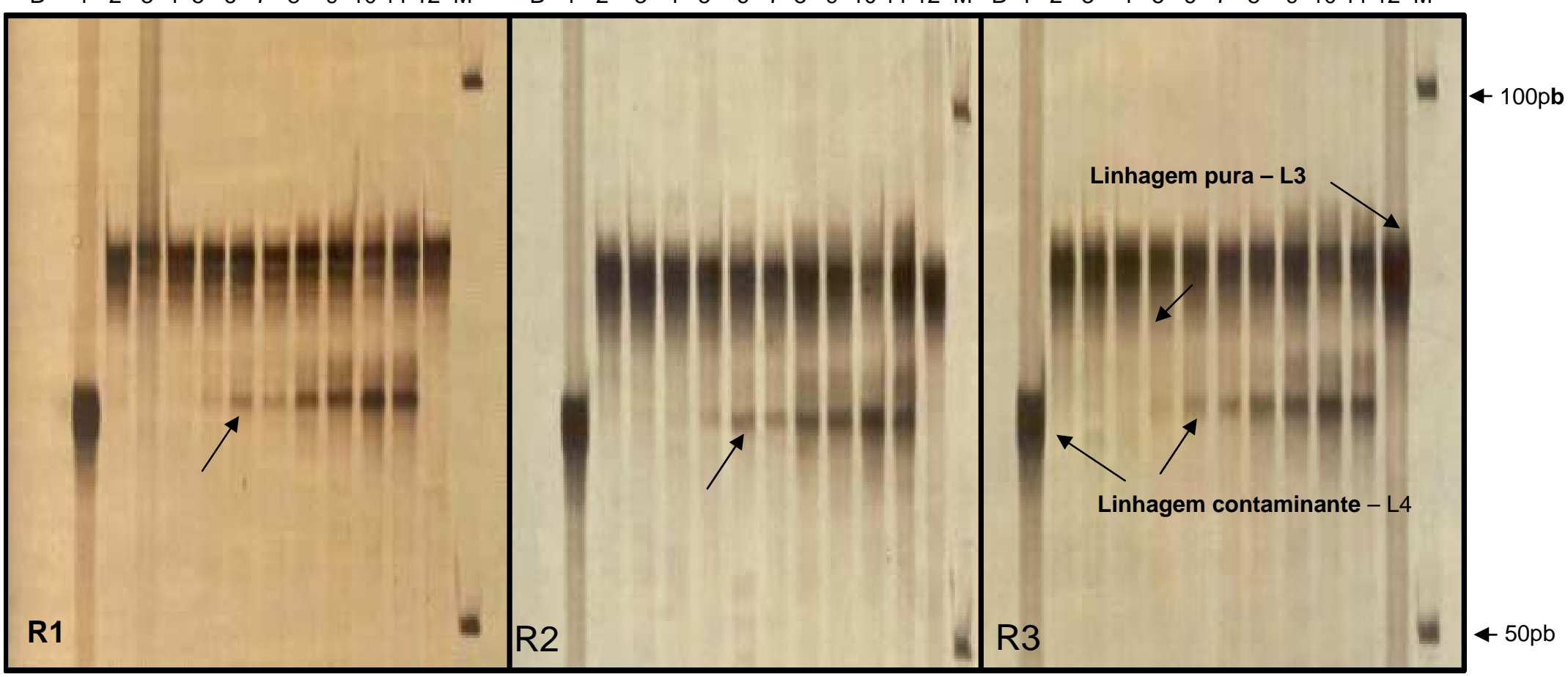

Figura 20 - Padrões de amplificação do microssatélite BNLG 240, resolvidos em gel de poliacrilamida em três repetições (R1, R2 e R3), obtidos de amostras de DNA de sementes das linhagens de milho L3 e L4 (ensaio B), diluídas em diferentes proporções, onde B corresponde à amostra testemunha ou branco, 1(T13) - corresponde à proporção 100\%L3+0\%L4, 2(T14) - 99,99\%L3+0,01\%L4, 3(T15) - 99,987\%L3+0,013\%L4, 4(T16) 99,98\%L3+0,02\%L4, 5(T17) - 99,96\%L3+0,04\%L4, 6(T18) - 99,9\%L1+0,1\%L2, 7(T19) - 99,8\%L3+0,2\%L4, 8(T20)- 99\%L3+1\%L4, 9(T21) - 98\%L3+2\%L4, 10(T22) - 95\%L3+5\%L4, 11(T23) - 90\%L3+10\%L4, 12(T24) 0\%L3+100\%L4 e M corresponde ao marcador com 50pb de peso molecular (Promega) 


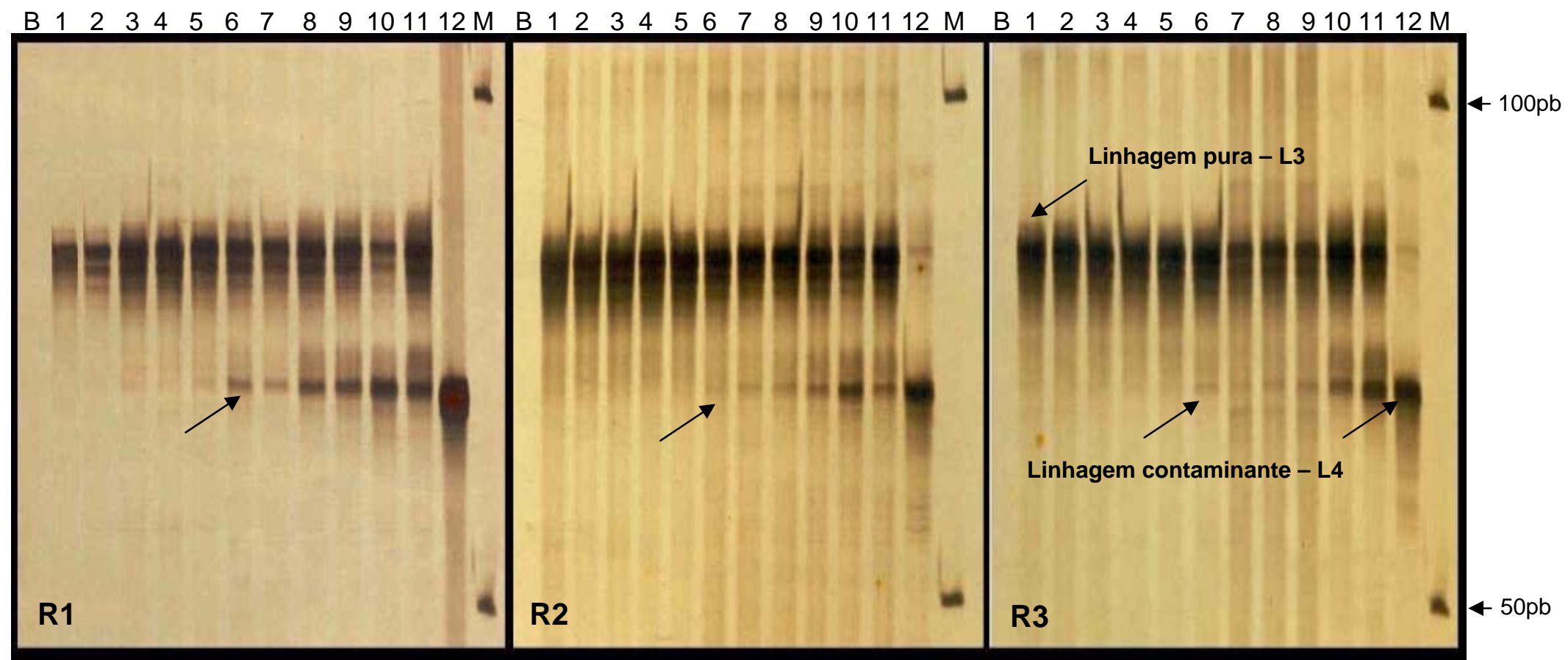

Figura 21 - Padrões de amplificação do microssatélite BNLG 240, resolvidos em gel de poliacrilamida em três repetições (R1, R2 e R3), obtidos de amostras de DNA de folhas de plântulas das linhagens de milho L3 e L4 (ensaio B), diluídas em diferentes proporções, onde B corresponde à amostra testemunha ou branco, 1(T13) corresponde à proporção 100\%L3+0\%L4, 2(T14) - 99,99\%L3+0,01\%L4, 3(T15) - 99,987\%L3+0,013\%L4, $4(\mathrm{~T} 16)-99,98 \% \mathrm{~L} 3+0,02 \% \mathrm{~L} 4,5(\mathrm{~T} 17)-99,96 \% \mathrm{~L} 3+0,04 \% \mathrm{~L} 4,6(\mathrm{~T} 18)-99,9 \% \mathrm{~L} 1+0,1 \% \mathrm{~L} 2, \quad 7(\mathrm{~T} 19)-$ 99,8\%L3+0,2\%L4, 8(T20)- 99\%L3+1\%L4, 9(T21) - 98\%L3+2\%L4, 10(T22) - 95\%L3+5\%L4, 11(T23) 90\%L3+10\%L4, 12(T24) - 0\%L3+100\%L4 e M corresponde ao marcador com 50pb de peso molecular (Promega) 


\subsection{Comparação entre marcadores morfológicos e moleculares para determinação de pureza varietal}

No método molecular, em todos os tratamentos analisados, foi possível detectar a presença da linhagem contaminante nas amostras com misturas em níveis de até $1 \%$ de contaminação. Assim, comparado com o método de análise baseado em marcadores morfológicos, tanto a segurança como a eficiência na detecção foram consideravelmente maiores, inclusive com possibilidade de observação da variação na intensidade de bandas características das linhagens contaminantes. Isto permitiu a estimativa de maior ou menor nível de contaminação, mesmo sem quantificá-la.

As amostras analisadas pela observação de descritores morfológicos de sementes, plântulas e plantas apresentaram erros de identificação na maioria dos tratamentos. Os resultados médios não alcançaram 100\% de acertos, demonstrando que a análise através de descritores morfológicos pode resultar em maior possibilidade de equívoco na decisão a respeito da rejeição ou aceite dos lotes. Principalmente em avaliações envolvendo genótipos semelhantes fenotipicamente ou com ampla variabilidade dentro de um mesmo genótipo.

Por outro lado, a técnica de microssatélites demonstrou alta sensibilidade na detecção de DNA contaminante nas amostras, com resultados confiáveis em simulações de proporções de até 1:1000, correspondendo a 0,1\% de contaminação. Além da maior precisão, outra vantagem da análise com microssatélite é a possibilidade de utilização de amostra composta com DNA de várias sementes que pode, inclusive, representar uma das quatro repetições exigida pelas RAS (Brasil, 1992). Essa possibilidade, associada ao uso de vários iniciadores polimórficos entre os vários genótipos de um programa de produção de sementes, permite a realização de reações de amplificação capazes de detectar mais de um cultivar contaminando a amostra, com segurança e eficiência. Isso significa menor custo e agilidade dentro dos programas de controle de qualidade. 
A comparação da eficiência no uso de marcadores moleculares e morfológicos para a determinação de pureza varietal foi realizada anteriormente por Orman et al. (1991) e Negut \& Sarca (1994), com resultados mais consistentes em análises com marcadores moleculares isoenzimáticos em comparação aos morfológicos. Para esses autores, a utilização de isoenzimas torna a análise mais precisa e rápida, com capacidade de determinação da porcentagem de contaminação com outros cultivares antes do período de colheita dos campos de sementes. Orman et al. (1991) ainda acrescentaram que a utilização em conjunto dos marcadores morfológicos e moleculares torna a determinação da pureza genética e varietal, mais confiável em milho.

Trabalhos envolvendo comparação entre marcadores moleculares microssatélites e marcadores morfológicos para determinação de pureza tanto varietal como genética são escassos. Salgado (2001), pesquisando a possibilidade de uso de marcadores morfológicos, isoenzimáticos e microssatélites para determinar pureza varietal em lotes de sementes híbridas de milho observaram que todos os marcadores foram satisfatórios, mas os microssatélites foram mais precisos, rápidos e eficientes em comparação aos demais.

Portanto, comparando-se o uso de marcadores moleculares microssatélites com os morfológicos realizados tanto em sementes, como em plântulas e plantas em diferentes estádios de desenvolvimento, observou-se maior precisão nas análises com microssatélites para a avaliação de pureza varietal. Assim, além de mais eficiente, a metodologia molecular apresenta vantagens como maior rapidez de execução, necessidade de pouco espaço de trabalho e também de mão de obra. A possibilidade de uso de DNA isolado a partir de sementes e da amplificação de amostra constituídas por muitas sementes também contribui para uma recomendação mais segura dos microssatélites em testes de rotina de laboratórios de sementes. 


\section{CONCLUSÕES}

Marcadores morfológicos observados em sementes, plântulas e plantas são pouco eficientes para a determinação da pureza varietal em lotes de sementes, quando a presença de genótipos contaminantes não é tolerada; como ocorre em lotes de linhagens de milho.

A técnica de microssatélites é eficiente para determinar de maneira consistente a presença de sementes de genótipos contaminantes em lotes de linhagem de milho. O sucesso na detecção é observado em níveis superiores ou iguais a $1 \%$ de contaminação, mediante o uso de amostras com várias sementes ou folhas de plântulas. A sensibilidade da técnica pode chegar a $0,1 \%$ de detecção de DNA contaminante, que corresponde a identificação segura de uma semente contaminante em amostra com mil sementes.

O DNA obtido a partir de sementes é satisfatório para análises envolvendo estudos moleculares com marcadores microssatélites. $O$ uso de amostras contendo elevado número de sementes contribui para a economia de tempo e espaço na obtenção dos resultados, especialmente no que diz respeito à determinação de pureza varietal em linhagens de milho. 


\section{REFERÊNCIAS BIBLIOGRÁFICAS}

ANDREOLI, C. Mistura varietal: aspectos genéticos e físicos na produção de sementes. Informativo ABRATES, v.1, n.3, p.32-36, 1992.

ASSOCIATION OF OFFICIAL SEED ANALYST - AOSA. Cultivar purity testing. Lansing, 1991. 371p.

ASSOCIATION OF OFFICIAL SEED ANALYST - AOSA,. Seed vigor testing handbook. Lansing, 1983. 88p.

BENITO, C.; FIGUEIRAS, A.M.; ZARAGOZA, C.; GALLEGO, F.G.; de la PEÑA, A. Rapid identification of triticeae genotypes from single seeds using polymerase chain reaction. Plant Molecular Biology, v.21, p.181-183, 1993.

BOITEUX, L.S.; FONSECA, M.E.N.; SIMON, P.W. Effects of plant tissue and DNA purification method on Randomly Amplified Polymorphic DNA-based genetic fingerprinting analysis carrot. Journal of Society of Horticultural Science, v.124, n.1, p.32-38, 1999.

BRASIL, MINISTÉRIO DA AGRICULTURA E REFORMA AGRÁRIA, Decreto-lei 9456 de 28 de abril de 1997. Seção 1. Lei de proteção de cultivares. Diário Oficial da União.

BRASIL, MINISTÉRIO DA AGRICULTURA E REFORMA AGRÁRIA. Lei n.10,711 5 de agosto 2003. Lei de sementes Diário Oficial da União. 
BRASIL, Ministério da Agricultura e Reforma Agrária. Regras para análise de sementes. Brasília: AGIPLAN, 1992. 365p.

CARVALHO, M.L.M. Aplicação de técnicas moleculares na avaliação da qualidade de sementes. In: BORÉM, A.; GIUDICE, M.P.D.; DIAS, D.C.S.S.; ALVARENGA, E.M. Biotecnologia e Produção de Sementes. Viçosa: Editora UFV, 2000, p.129-160.

CARVALHO, N.M.; NAKAGAWA, J. Sementes: ciência, tecnologia e produção. 4. ed. Jaboticabal: Funep, 2000. 588p.

CASEIRO, R.F.; MARCOS FILHO, J. Procedimento para a condução do teste de frio em sementes de milho: pré-esfriamento e distribuição do substrato o interior da câmara fria. Revista Brasileira de Sementes. v.24, n.2, p.06-11, 2002.

CHIN, E.C.; SENIOR, M.L.; SMITH, J.S.C. Maize simple repetitive DNA sequences abundance and allelic variation. Genome, v.39, p.866-873, 1996.

CHUNWONGSE, J.; MARTIN, G.B.; TANKSLEY, S.D. Pre-germination genotypic screening using PCR amplification of half-seeds. Theoretical Applied Genetics, v.86, p.694-698, 1993.

COOKE, R.J. The characterization and identification of crop cultivars by electrophoresis. Electrophoresis, v.5, p.59-72, 1984.

COOKE, R.J. Gel electrophoresis for identification of plant varieties. Journal of Chromatography, v.689, p.281-299, 1995.

COORDENADORIA DE ASSISTÊNCIA TÉCNICA INTEGRADA. Padrões de sementes para 1999/2000. Campinas, Coordenadoria de Assistência Técnica Integral, Secretaria de Agricultura e Abastecimento, Governo do Estado de São Paulo. 1999.

CRESTE, S.; TULMANN NETO, A.; FIGUEIRA, A. Detection of single sequence repeat polymorfisms in denaturing polyacrylamide sequencing gels by silver staining. Plant Molecular Biology Reporter, v.19, p.299-306, 2001. 
DITMER,W.P. Varietal determination made in seed laboratory. Journal of Seed Technology, v.3, n.2, p.42-47, 1979.

DIWAN; N; CREGAN, P.B. Automated sizing of fluorescent-labelled simple sequence repeats (SSR) markers to assay genetic variation in soybean. Theoretical Applied Genetics, v.95, p.723-733, 1997.

DORNBOS JR, D.L. Seed vigor In: BASRA, A.S. (Ed.) Seed Quality: Basic mechanisms and agricultural implications. New York: Food Products Press, 1994. p.45-80.

FANCELLI, A.L.; DOURADO-NETO, D. Ecofisiologia e fenologia In: FANCELLI, A.L.; DOURADO-NETO, D (Ed.). Produção de milho. Guaíba: Agropecuária , 2000. 360p.

FAO - FOOD AGRICULTURAL ORGANIZATION. Disponível em www.fao.org. Acesso em 10 de maio de 2004.

FERREIRA, M.E.; GRATTAPAGLIA, D. Introdução ao uso de marcadores moleculares em análise genética. 3.ed. Brasília:EMBRAPA-CENARGEN, 1998. 220p.

GOODMAN, M.M.; PATERNIANI, E. The races of maize III. Choices of appropriate characters for racial classification. Economic of Botany, v.31, p.265-271, 1969.

GUIMARÃES, C.T.; MOREIRA, M.A. Genética molecular aplicada ao melhoramento de plantas. In: BORÉM, A. Melhoramento de espécies cultivadas. Viçosa: Editora UFV, 1999. p.715-740.

GUPTA, P.V.; BALYAN, H.S.; SHARMA, P.C. Microsatellites in plants: a new class of current markers. Current Science, v.70, n.1, p.45-54, 1996.

HAMPTON, J.G.; TEKRONY, D.N. Accelerated ageing test. In: _ Handbook of vigour tests methods. Zürich: International Seed Testing Association, 1995. p.35-50. 
HEARNE, C.M.; GHOSH, S.; TODD, J.A. Microsatellites for linkage analysis of genetic traits. Trends in genetic, v.8, p.288-294, 1992.

HEUN, M.; HELENTJARIS, T. Inheritance of RAPDs in $\mathrm{F}_{1}$ hybrids of corn. Theoretical Applied Genetics, v.85, p.961-968, 1993.

HOISINGTON,D.; KHAIRALLAH, M.; GONZÄLEZ DE LEON, D. Laboratory Protocols: CIMMYT Applied Molecular Genetics Laboratory. 2 ed. CIMMYT, México, 1994.

HOREJSI, T.; BOX, J.M. SATAUB, J. Efficiency of randomly amplified polymorphic dna to sequence characterized amplified region marker conversion and their comapartive polymerase chain reaction sensitivity in cucumber. Journal of Society of Horticultural Science, v.124, n.2, p.128-135, 1999.

INTERNATIONAL SEED TESTING ASSOCIATION - ISTA. Rules for seed testing. Zürich, 1996. 44p.

KIRST, M. Desenvolvimento de sistemas de genotipagem multilocos semiautomatizados, baseados em marcadores microssatélites, e sua aplicação em espécies do gênero Eucaliptus. Viçosa, 1999. 150p. Tese (Magister Scientiae) Universidade Federal de Viçosa.

LANZA, M.B.; GUIMARAES, C.T.; SCHUSTER, I. Aplicação de marcadores moleculares no melhoramento genético. Informe Agropecuário, v.21, n.204, p.97-108, 2000.

MACHADO, J.C. Patologia de sementes: significado e atribuições. In: CARVALHO, N.M.; NAKAGAWA, J.(Ed.) Sementes: ciência, tecnologia e produção. 4.ed. Jaboticabal: Funep, 2000. p. 522-588.

MARCOS FILHO, J. Testes de vigor: importância e utilização. In: KRZYZANOWSKI, F.C.; VIEIRA, R.D.; FRANÇA NETO, J.B. (Ed.). Vigor de sementes: conceitos e testes. ABRATES, 1999. cap.1, p.1-21. 
MARCOS FILHO, J.; MCDONALD, M.B.; TEKRONY, D.M.; ZHANG, J. RAPD fragment profiles from deterioration soybean seeds. Seed Technology, v.19, n.1, p.34-44, 1997.

McDONALD, M.D. Genetic purity: from eletrophoresis to RAPDs. IN: ANNUAL CORN \& SORGHUM INDUSTRY RESEARCH CONFERENCE, Inc. Washington, D.C.: American Seed Trading Association, 1995. p.256-271,

McDONALD, M.D.; ELLIOT, L.J.; SWEENEY, P.A. DNA extraction from dry seeds for RAPD analyses in varietal identification studies. Seed Science and Technology, v.22, n.1, p.171-176, 1994.

MEESANG, M.; RANAMUKHAARACHCHI, S.L.; PETERSEN, M.J.; ANDERSEN, S.B. Soybean cultivar identification and genetic purity analysis using microsatellite DNA markers. Seed Science and Technology, v.29, n.3, p.637-645, 2001.

MENEZES, C.C.E.; SEDIYAMA, T.; MCDONALD, M.B.; DIAS, D.C.F.S. Análise de pureza genética e discriminação de cultivares de vinca (Catharanthus roseus L.) usando "Random Amplified Polymorphic DNA" em DNA extraído de sementes e folhas. Revista Brasileira de Sementes, v.24, n.1, p.279-285, 2002.

MOREIRA, C.T; SOUZA, P.I.M.; FARIAS NETO, A.L.; ALMEIDA, L.A. Ocorrência de variações na coloração do hilo de sementes de cultivares de soja. [Glicyne max (L.) Merril] Planaltina: EMBRAPA Cerrados, 1999. (Comunicado Técnico, 5)

MORGANTE, M.; OLIVIERI, A.M. PCR-amplified microsatellites as markers in plant genetic. The Plant Journal, v.3, n.1, p.175-182, 1993.

MURPHY, R.W.; SITES, J.W.; BUTH, D.G. et al. Proteinsl: isozyme electrophoresis. In: HILLIS, D.M.; MORTIZ, C. Molecular Systematics. Sunderland: Sinauer Associates, 1990. p. 45-126.

NAKAGAWA, J. Testes de vigor baseados na avaliação de plântulas. In: KRZYZANOWSKI, F.C.; VIEIRA R.D.; FRANÇA NETO, J.B. (ed.). Vigor de sementes: conceitos e testes. Londrina ABRATES, 1999. p.2.1-2.23 
NEERGAARD, P. Seed Pathology. London McMillan, 1999. v.1,839p.

NEGUT, E.L.; SARCA, V. Relation ship between electrophoresis and growouts in identification of self pollinated plants outcrosses in maize hybrid seed. Romanian Agricultural Research, v.1, p.23-26, 1994. Compact Disc.

OGLIARI, J.B.; BOSCARIOL, R.L.; CAMARGO, L.E.A. Optimization of PCR amplification of maize micosatellite loci. Genetics and Molecular Biology, v.23, n.2, p.395-398, 2000.

OLUFOWOTE, J.O.; XU, Y.; CHEN, $\mathrm{X}$ et al. Comparative evaluation of within-cultivars variation of rice (Oryza sativa L.) using microsatellites and RFLP markers. Genome, v.40, p.370-378, 1997.

ORMAN, B.A.; LAWRANCE, G.D.; DOWNES, P.M. Assessment on maize inbred genetic purity by isoenzymes eletrophoresis. Seed Science and Technology, v.19, n.2, p.527-553, 1991.

PAUKENS, J. Methods for determination of cultivar trueness and purity in maize (Zea mays L.). Seed Science and Technology, v.3, n.1, p.176-185, 1975.

PAUKENS, J.; DHESI, N.S. Cultivar verification methods used in Canada. Seed Science and Technology, v.6, n.3, p.585-592, 1978.

PAYNE, R.C. Variety testing by official AOSA seed laboratories. Journal of Seed Technology, v.10, n.1, p.24-36, 1986.

PIMENTEL GOMES, F. Curso de estatística experimental. 12ed. São Paulo, Nobel, 1987. 466p.

PHELPS, T.L.; HALL, A.E.; BUCHNER, B. Microsatellite repeat variation within Y1 gene of maize teosine. The Journal of Heredity, v.87, n.5, p.396-399, 1996.

PIERCE, L.C.; BREWBAKER, J.L. Applications of isozyme analysis in horticultural science. Hortiscience, v.8, n.1, p.17-22, 1973.

RAMALHO, M.A.; SANTOS, J.B.; PINTO, C.B. Genética na agropecuária. Lavras: FAEPE, 1990. 359p. 
REVILLA, P.; TRACY, W.F. Morphological characterization and classification of openpollinated sweet corn cultivars. Journal of American Society of Horticultural Science, v.120, n.1, p.112-118, 1995.

RIEDY, M.F.; HAMILTON, W.J.; AQUADRO, C.F. Excess of non-parental bands in offspring from known primate pedigree assayed using RAPD PCR. Nucleic Acid Research, v. 20, p.918, 1992.

RONGEWEN, J.; AKKAYA, M.S.; BHAGWAT, A.A.; LAVI, U.; CREGAN, P.B. The use of microsatellite DNA markers for soybean genotype identification. Theoretical Applied Genetics, v.90,1 n.1, p.43-48. 1995.

RUSSEL, J.; FULLER, J.; YOUNG, G. et al. Discriminating between barley genotipes using microsatelites markers. Genome, v.40, p. 442-450, 1997.

SALGADO, K.C.C. Certificação da pureza genética em sementes híbridas de milho por meio de marcadores morfológicos e moleculares. Lavras, 2001. 67p. Dissertação (Mestrado) Universidade Federal de Lavras.

SANTOS, C. (ed.) ANUARIO BRASILEIRO DE MILHO 2003. Santa Cruz do Sul: Editora Gazeta Santa Cruz, 2003. 136p.

SAS institute. The SAS system for windows: version 6.12 (compact disc). Cary, SAS Institute, 1996.

SCHIMIDT, J.W. A plant breeder looks at the problem of distinguishing varieties. Journal of Seed Technology, v.3, n.2, p.57-60, 1979.

SCHNEIDER, K. DOUCHES, D.S. Assessment of PCR-based simple sequence repeats to "fingerprinting" North American potato cultivars. American Potato Journal, v.74, p.149-160, 1997.

SCHUSTER, I.; QUEIROZ, V.T.; BARROS, E.G.; MOREIRA, M.A. Utilização de marcadores moleculares na identificação de mistura varietal em soja. Genetics and Molecular Biology, v.23 (supl.), n.3, p.209, 2000. 
SCHUSTER, I. QUEIROZ, V.T.; TEIXEIRA, A.I.; BARROS, E.G.; MOREIRA, M.A. Determinaçao da pureza varietal de sementes de soja com auxílio de marcadores moleculares microssatélites. Pesquisa Agropecuária Brasileira, v.39, n.3, p.247-253, 2004.

SENIOR, M.L.; HEUN, M. Mapping maize microsatellite and polymerase chain reaction confirmation of the targed repeats using CT primer. Genome, v.36, p.884889, 1993.

SENIOR, M.L.; CHIN, E.C.L.; LEE, M.; SMITH, J.S.C.; STUBER, C.W. Simple sequence repeat markers developed from maize found in GENBANK Database: map contruction. Crop Science, v.36, p.1676-1683, 1996.

SINGH, N.N.; SARKAR, K.R. Anthocyanin pigmentation in various parts of maize plant in relation to line development and seed certification. Seed Science Research, v.10, n.1, p.18-26, 1982.

SMITH,J.S.C. Identification of cultivated varieties by nucleotide analysis. In: WRIGLEY, C.E. (Ed.). Identification of food-grain varieties. St. Paul Minnesota: American Association of Cerela Chemists, 1995. p.131-150.

SMITH, J.S.C.; SMITH, O.S. The description and assessment of distances between inbred lines of maize: II. The utility of morphological, biochemical and genetic descriptors and scheme for testing of distinctiveness between inbred lines. Maydica, v.34, p.151-161, 1989.

SMITH, J.S.C.; REGISTER III, J.C. Genetic purity and testing technologies for seed quality: a company perspective. Seed Science Research, v.8, n.2, p.285-293, 1998.

SRIVASTAVA, J.M.; AGRAWA, B.D. Phenotypic variability in paternal lines of some released maize hybrids. Seed Research, v.13, n.1, p.8-15, 1985.

STAUB, J.; BACHER, J.; POETTER, K. Sources of potential errors in the aplication of random amplified polymorphic DNAs in cucumber. HortScience, v.31, n², p.262266, 1996. 
TARAMINO, G.; TINGEY, S. Simple sequence repeats for germoplasm analysis and mapping in maize. Genome, v.39, p.277-287, 1996.

TAUTZ, D. Hypervariability of simple sequences as a general source for polymorphic DNA markers. Nucleic Acids Research, v.17, p.6463-6471, 1989.

VIEIRA, E.S.N.; VON PINHO, E.V.R.; VIEIRA, M.G.G.C.; MANN, R.S. Similaridade genética entre cultivares de feijão do grupo carioca por meio de marcadores morfológicos e moleculares de DNA visando certificação da pureza genética. Revista Brasileira de Sementes, v.23, n.2, p.43-50, 2001.

VON-PINHO, E.V.R. Consequências da autofecundação indesejável na produção de sementes híbridas de milho. Piracicaba, 1995. 130p. Tese (Doutorado) Escola Superior de Agricultura "Luiz de Queiroz", Universidade de São Paulo.

VON-PINHO, E.V.R.; VON-PINHO, R.Z.; CICERO, S.M. Utilização de caracter'siticas morfológicas para avaliação de pureza genética em sementes híbridas de milho. Pesquisa Agropecuária Brasileira, v.32, n.9, p.941-949, 1997.

VOS, P.; HOGERS, R.; BLEEKER, M.; REIJANS, M.; Van de LEE, T.; HOMES, T.; FRIJTERS, A.; POT, J.; PELEMAN, J.; KUIPER, M.; ZABEAU, M. AFL: a new technique for DNA firgerprinting. Nucleic Acid Research, v.23, p.4407-4414, 1995.

WELSH, J.; MCCLELLAND, M. Fingerprinting genomes using PCR with arbitrary primers. Nucleic Acid Research, v.18, n.24, p.7213-7218, 1990.

WILLIAMS, J.G.K.; KUBELIK, A.R.; LIVAK, K.J.; RAFALSKI, J.A.; TINGEY, S.D. DNApolimorphisms amplified by arbitrary primers ser useful as genetic markers. Nucleic Acid Research, v.18, n.24, p.6531-6535, 1990.

WU, K.; JONES, R.; DANNEBERGER, L.; SCOLNIK, A. Detection of micosatellite polymorphisms without cloning. Nucleic Acid research, v.22, n.15, p.3257$3258,1994$. 
WYCK, R.D. Prodution of hybrid seed corn. In: SRAGUE, G.F. DUDLEY, J.W. Corn and corn improvement. 3 ed. Madison: American Society of Agronomy, 1988. p.565-607.

YU, Y.G.; SAGHAI MARROF, M.A., BUSS, G.R., MAUGHAN, P.J., TOLIN, S.A. RFLP and microssatellite mapping of a gene for soybean mosaic virus resistance. Phytopathology, v.24, n.1, p.60-64, 1994.

ZHANG, J. MCDONALD, M.B.; SWEENEY, M.P. Random amplified polymorphic DNA (RAPDs) from dry seeds of differing soybean and mayze genotypes. Seed Science and Technology, v.24, n.2, p.513-522, 1996. 


\section{APÊNDICES}



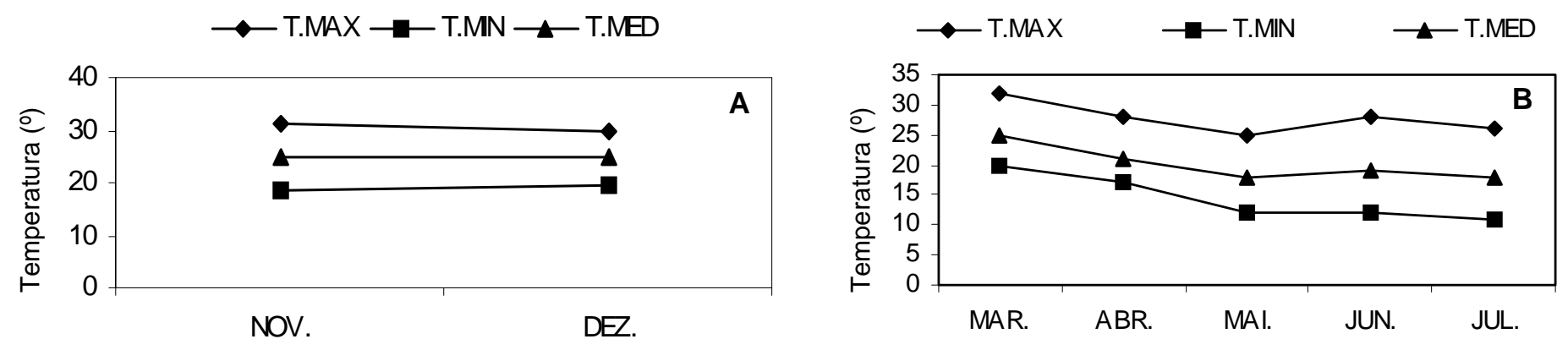

Ppt.(mm)

$\square$ Ppt.(mm)
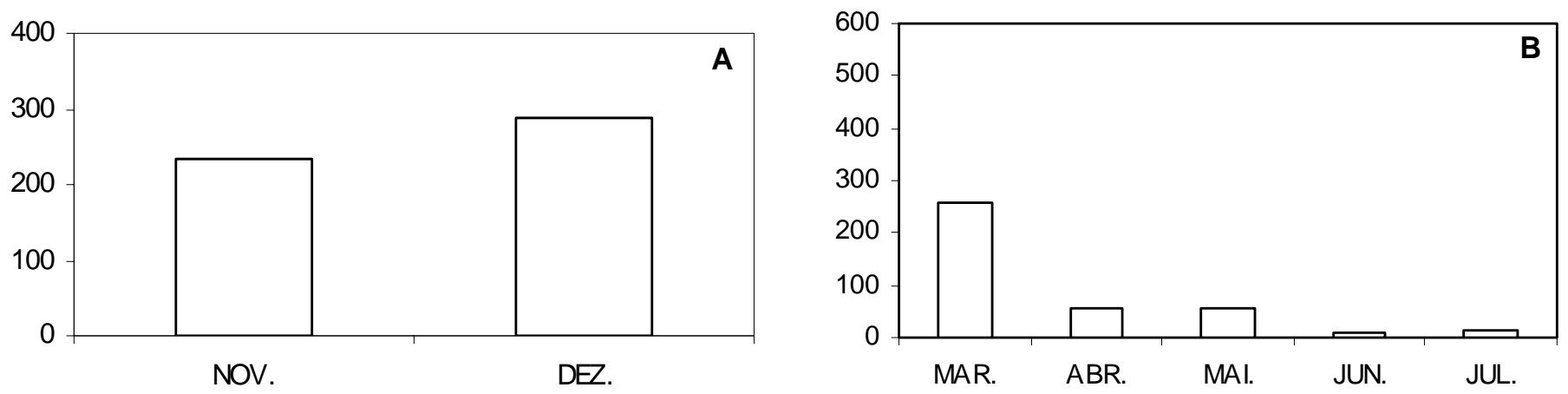

Apêndice 1 - Dados meteorológicos (temperatura e precipitação) referentes aos ensaios de Cravinhos - SP (A), conduzido no ano de 2002, e Piracicaba -SP (B), conduzido no ano de 2003 